\title{
Molecular phylogenetic systematics in the Dendrobiinae (Orchidaceae), with emphasis on Dendrobium section Pedilonum
}

\author{
M.A. Clements
}

\begin{abstract}
Clements, M.A. (Centre for Plant Biodiversity Research, Australian National Herbarium, G.P.O. Box 1600, Canberra, A.C.T. 2601, Australia) 2003. Molecular phylogenetic systematics of the Dendrobiinae (Orchidaceae), with emphasis on Dendrobium section Pedilonum. Telopea 10(1): 247-298. Molecular systematic research using the internal transcribed spacer (ITS) region of the 18-26S nuclear ribosomal DNA repeat unit, on representatives of most taxonomic units within the Dendrobiinae has provided independent support, in addition to morphological and biological data, for the phylogenetic reassessment of the taxon. At a broad level, the Dendrobiinae is polyphyletic with Epigeneium forming an independent clade; Dendrobium section Oxystophyllum is deeply embedded within one of the outgroups, subtribe Eriinae: Podochileae; and the remaining taxa isolated into two major groups, viz the Asian and Australasian clades. A detailed study of part of the Asian clade, with emphasis on representatives of the morphologically based Dendrobium section Pedilonum, groups species into seven major clades. Dendrobium section Pedilonum is shown to be non-monophyletic with most species previously interpreted as belonging to it being well isolated from $D$. secundum, the designated type of that taxon, and interspersed amongst representatives of D. section Calcarifera, Calyptrochilus, Cuthbertsonia, Dendrobium, Dolichocentrum, Oxyglossum and Platycaulon. Dendrobium section Rhopalanthe, which separates the two major clades containing representatives of $D$. section Pedilonum, is itself paraphyletic with representatives of sections Aporum and Bolbidium embedded within it. These molecular results, combined with morphological data, provide a strong basis for a reassessment of the phylogeny of part of the study taxon. A reclassification of this part of the Dendrobieae and Podochileae is provided in Appendix 2, including: re-instatement of the genus Oxystophyllum (Eriinae: Podochileae); the recognition and description of subtribes Epigeneiinae and Grastidiinae (Dendrobieae); recognition or re-instatement of the genera Aporum, Callista, Ceraia, Coelandria, Eurycaulis, Distichorchis, Pedilonum as distinct from Dendrobium; the elevation of Anisopetala to generic status; and where necessary the transfer of the appropriate species from Dendrobium to these genera.
\end{abstract}

\section{Introduction}

The Dendrobiinae Lindl. comprises a diverse group of epiphytic, lithophytic and terrestrial herbs classified in six genera in current usage containing approximately 1150 species (Dressler 1993). Species within these genera are distributed predominantly throughout paleotropical regions with extensions to temperate Asia (Seidenfaden 1985, 1992, Seidenfaden \& Woods 1992), the Philippines (Ames 1908, Quisumbing 1934), the Malay archipelago (Smith 1905, Comber 1990, Wood et al. 1993), New Guinea (Schlechter 1912, van Royen 1979), Australia (Rupp 1947, Dockrill 1969, Jones 1999), New Caledonia (Hallé 1997), south-west pacific islands (Lewis \& Cribb 1989, 1992, Kores 1991, Cribb \& Whistler 1996), and New Zealand (Moore 1972). Members of the Dendrobiinae vary considerably in their floral and vegetative morphology, especially in the southern part of their range, making them prime candidates for studies of character evolution. The subtribe has already been the focus of a broad taxonomic study (Brieger 1981) and phylogenetic studies based on analysis 
of chloroplast DNA restriction sites (Yukawa et al. 1993, 1996) and chloroplast DNA sequences (Yukawa et al. 2000).

The subtribe Dendrobiinae was created in 1829, as a section within the tribe Malaxideae Lindl., accompanying the description and illustration of Dendrobium secundum (Blume) Lindl. in the Botanical Magazine (Lindley 1829). Thereafter Lindley enumerated his concept of Dendrobiinae, embracing 20 genera and grouping them together on the possession of two, four or eight pollinia (Lindley 1830). Dendrobium Sw. was grouped together with ten other genera including Aporum Blume, Macrostomium Blume, Bulbophyllum Thouars and Polystachya Hook. on account of the possession of four naked pollinia. Most subsequent authors including Lindley (1851), Reichenbach (1861), Bentham (1881), Bentham and Hooker (1883), Pfitzer (1882, 1889), Schlechter (1905, 1912, 1926), Dressler and Dodson (1960) and Dressler (1972, 1979, 1981), have progressively narrowed the interpretation of the Dendrobiinae so that Dressler (1993), in his most recent classification of the family, recognised only six genera with approximately 1150 species within the subtribe, viz Cadetia Gaudich. (67 spp.), Dendrobium (c. 900 spp.), Diplocaulobium Kraenzl. (94 spp.), Epigeneium Gagnep. (12 spp.), Flickingeria A. Hawkes (70 spp.) and Pseuderia Schltr. (4 spp.).

However, the systematic position and presumed monophyly of the Dendrobiinae sensu Schlechter (1926) was questioned when Brieger (1981) published an account of the group as part of a revised classification of the family. He noted that Lindley had united a great number of taxa into two huge collective genera, Dendrobium and Eria. Thereafter, with the description of many additional species, it became necessary to create a sometimes complex, infra-generic structure to accommodate the various forms being described within each of these large genera, e.g. Bentham and Hooker (1880), Pfitzer (1889), Kraenzlin (1910), Schlechter (1912). However, in Kraenzlin's complex, and confusing thesis on the Dendrobiinae, he proposed the re-instatement and recognition of several segregate genera within the subtribe, viz. Callista Lour., Inobulbum (Schltr.) Schltr. et Kraenzl. [as Inobulbon], Sarcopodium Lindl., Diplocaulobium (Rchb.f.) Kraenzl. and Desmotrichum Blume. Thereafter, the situation changed slightly with a push towards the acceptance or recognition of several of these segregate genera, so that by 1980 typically in the scientific literature six genera were recognised within the Dendrobiinae and eight in the Eriinae (Dressler 1981). Brieger (1981) took the classification of the subtribes Dendrobiinae and Eriinae to new levels of confusion, combining them into one large subtribe containing six informal categories that he termed 'Genera-Series' based on overall perceived similarities of vegetative and floral morphology. He also reinstated, recognised and described many new genera within this framework. The systematic position of the Dendrobiinae also came under scrutiny as a result of studies of embryological development, from representatives of the Orchidaceae including the Dendrobiinae (Clements 1995, 1996, 1999, unpublished). These studies provided independent evidence that the Dendrobiinae, and more particularly Dendrobium, was polyphyletic with respect to the Eriinae (Podochileae), where different embryo types were identified within these taxa. Results from phylogenetic analyses of $r b c \mathrm{~L}$ and matK plastid sequences and cpDNA restriction sites in the Dendrobiinae (Yukawa et al. 1993, 1996, 2000, Yukawa \& Uehara 1996) also supported similar conclusions. These authors concluded that the Dendrobiinae is polyphyletic and comprises four major clades: (i) Pseuderia which was shown to belong to the Podochilinae [?](Yukawa et al. 1996); (ii) Epigeneium; (iii) Dendrobium Clade 1 containing species predominantly inhabiting mainland Asia, including the type of the genus; and (iv) Dendrobium Clade 2 containing taxa including Cadetia, Diplocaulobium and Flickingeria widespread mostly in Australasia and the Pacific Islands. It was on the basis of these results and some unpublished data that genera such as Dockrillia Brieger (Clements \& Jones 1996), Grastidium Blume (Clements \& Jones 1997), Inobulbum (Schltr.) Schltr. et Kraenzl. (Clements \& Jones 1998a), Tetrodon 
(Kraenzl.) M.A.Clem. et D.L.Jones (Clements and Jones 1998a), Winika M.A.Clem., D.L.Jones et Molloy (Clements et al. 1997), and Cannaeorchis M.A.Clem. et D.L.Jones (Clements \& Jones 1998b) from the Malesian and Australasian regions have been recognised, reinstated or described.

\section{Dendrobium section Pedilonum}

One characteristic group of species in Dendrobium, often with extremely colourful flowers, and frequently encountered throughout the Malesian region, which as yet has received little attention at the molecular level, is Dendrobium section Pedilonum and its associated sections Calyptrochilus, Cuthbertsonia and Oxyglossum. Brieger (1981) treated these taxa in genus series Dendrobia, all as part of the genus Pedilonum, and he added two further sections formerly treated as part of Dendrobium, section Sanguinolenta and section Platycaulon. Dendrobium section Pedilonum was described by Blume in 1825 but then, almost immediately, he treated it at generic rank (Blume 1825). Blume considered Pedilonum distinct from Dendrobium by the absence of an articulate, slipper shaped labellum and included six species in the genus. He divided Pedilonum into two unnamed sections: one, containing P. kuhlii and P. hasseltii, was distinguished by possession of an elongate, laterally compressed sack formed by fusion of the lateral sepals not adnate to the labellum claw; the second, containing $P$. secundum, $P$. undulatum, P. biflorum and P. erosum, was distinguished by lateral sepals forming an elongate spur often adnate to the labellum claw. Over 140 species have since been assigned to Pedilonum all as Dendrobium, mainly by Miquel (1859), Pfitzer (1888), Hooker (1890), Ridley (1896), Bailey (1902), Kraenzlin (1910), Schlechter (1905, 1912), and Seidenfaden (1985).

Kraenzlin (1910) in his monograph of Dendrobium divided the genus into ten subgenera, including subgenus Pedilonum, all roughly equivalent to the sections of earlier authors. He treated 137 species within subgenus Pedilonum and further divided it into five sections, viz. Secunda, Glomerata, Capitata, Ceratobium and Brevisaccata. Of these five sections only the first three contain species closely related to Pedilonum as considered by authors such as Schlechter $(1910,1911 \mathrm{a} \& \mathrm{~b}, 1912,1914,1921,1923 \mathrm{a} \& \mathrm{~b}$, 1925), Smith (1908b, 1909, 1910a,b \& c, 1911a, b \& c, 1912, 1913, 1916, 1917, 1918, 1919, $1020,1922,1924,1925,1926,1927 a$ \& b, 1928a,b \& c, 1929, 1930, 1933a \& b, 1934a ,b \& c) and van Royen (1979).

Schlechter (1912), in his account of Dendrobium in the Orchids of German New Guinea, considered section Pedilonum to be part of subgenus 'Eu-Dendrobium', which he distinguished as those taxa possessing: leaves upon distinct sheaths; stems pseudobulbous or fleshy for their whole length; and the absence of any longitudinal splitting of the labellum into well defined lobes. He also considered that section Pedilonum shared these characteristics with sections Dendrobium, Platycaulon, Calyptrochilus, Cuthbertsonia and Oxyglossum. He further characterised section Dendrobium as having the habit of two- to multi-flowered lateral inflorescences with spreading flowers, and an undivided, rotund labellum in most cases internally finely papillate. Section Platycaulon was characterised by the much-flattened, compressed pseudobulbs and the labellum veins thickened frequently into ridges. Section Calyptrochilus was characterised by the labellum, which at the apex is turned inwards and cucullate, and with finely serrate margins, an elongated column-foot adnate with the margins of the labellum forming a spur. Section Cuthbertsonia included species with short pseudobulbs but with a peculiar papillose covering of the leaves and outside of the flowers, particularly the ovaries; the flowers werecharacteristic of those found in the previous section minus the serrate inward facing labellum apices. Section Oxyglossum was also characterised by the short pseudobulbs, two but occasionally 
multi-flowered inflorescence, an ovary with three to ten, sharp wings, and an attenuate labellum with a brightly coloured, sharp apex.

By comparison, Brieger (1981) recognised Pedilonum at generic rank with six sections, viz. Pedilonum, Calyptrochilus, Cuthbertsonia, Oxyglossum, Sanguinolenta (Calcarifera) and Platycaulon. Section Sanguinolenta was created by Brieger (1981) to account for a group of species typified by $D$. sanguinolentum, possessing 'stem axes uniformly cylindrical, with numerous leaves, rarely non-uniformly thickened, not flattened; labellum narrow at base, broadening and with erect margins, indistinct, rarely distinctly trilobed'. The section is more or less equivalent to Smith's $D$. section Calcarifera which he characterised as differing from section Pedilonum by the labellum which is larger, broader, and usually more or less lobed and has a tooth protruding into the mentum. Based upon Brieger's interpretation of the subtribe, Rauschert (1983) made hundreds of automatic transfers to various genera including Pedilonum although authors such as Seidenfaden (1985) and Cribb et al. (1985) criticised these taxonomic changes.

Since there is obviously much confusion surrounding the status and circumscription of Pedilonum and associated taxa, I decided to investigate furthur the relationships of such a prominent member of the Dendrobiinae in the Malesian region. The main purpose of this study was therefore to: (i) contribute to our understanding of the phylogenetic relationships in the Dendrobiinae; (ii) determine if Pedilonum and associated taxa are monophyletic, based on analyses of the internal transcribed spacer (ITS) region of 18-26S nuclear ribosomal DNA, an independent data set; and (iii) clarify the status of Pedilonum and allied taxa. This study also offers the opportunity to further unravel the confusion that currently surrounds the status of Dendrobium sens. lat., and subtribe Dendrobiinae and tribe Dendrobieae of which it is a part.

\section{Methods}

Plant material. Material of 75 species representative of genera in the Dendrobiinae and sections within Dendrobium, but in particular those associated with section Pedilonum, were used in this study. Outgroups were chosen on the basis of previous studies and are roughly equivalent to those used by Yukawa et al. $(1996,2000)$ and comprised species of Bryobium, Eria (Eriinae: Podochileae), Adelopetalum, Bulbophyllum, Oxysepala (Bulbophyllinae: Dendrobieae), Liparis (Malaxideae) and Drymoanthus (Aeridinae: Vandeae) (Appendix 1). Species used in this study were carefully chosen from amongst representatives of the c. 290 species in the study group for which sequences were available. Fresh leaf samples were collected either in the field or from cultivated plants of known provenance. All collections are vouchered and deposited at the Australian National Herbarium (CANB) (Appendix 1).

DNA extraction and PCR and sequencing procedures. Genomic DNA extraction and sequencing procedures used are the same as those described in the preparation of material for the analyses of the Diurideae (Clements et al. 2002). The complete sequence of the ITS1-5.8S-ITS2 region for each sample was edited and assembled from the sequencing chromatograms using Sequencher 3.0 software (Gene Codes Corporation). The sequences have been submitted to GenBank and given accession numbers as shown in Appendix 1.

Method of alignment and sequence analysis. Sequences were first aligned using the EclustalW program supplied by the Australian National Genomic Information Service (ANGIS) Multiple alignment parameters were set at the default values; a gap opening penalty of 10 (range 1-100), a gap extension penalty of 5 (range $0.10-100$ ) and gap separation penalty of 8 (range 1-50). Sequences were manually re-aligned, using 
BioEdit version 4.7.8. The re-aligned files were converted to PAUP/NEXUS format, exported to MacClade and analysed using PAUP version 4.0b4a. The most parsimonious trees were determined using a heuristic search algorithm with 100 replicates of random taxon entry, TBR branch swapping and the 'Multrees' option. Successive weighting (Farris 1969) was applied through recalculation of the rescaled consistency indices until a stable position was attained. Bootstrap analyses were done for both unweighted and weighted trees to determine the relative support for the resultant clades (Felsenstein 1985), and all minimal length trees saved. These equally parsimonious trees were summarised by generating a consensus tree.

\section{Results}

An overall assessment of the Dendrobieae, centered on the Dendrobiinae, was first undertaken through a sequence analysis of 23 species, representative of most major taxonomic groups used in previous studies of the group (Yukawa et al. 1993) including seven outgroup species, viz. Bryobium, Eria (Eriinae: Podochileae), Adelopetalum, Bulbophyllum and Oxysepala (Bulbophyllinae: Dendrodieae), Liparis (Malaxideae) and Drymoanthus (Aeridinae: Vandeae). The alignment used contained 786 nucleotide sites of which 324 were potentially parsimony-informative. Analysis of this computer based alignment produced 3 equally parsimonious trees; tree length $=1440$; consistency index $(\mathrm{CI})=0.5743$; retention index $(\mathrm{RI})=0.4853$; and rescaled consistency index $(\mathrm{RC})$ $=0.2787$. One of these trees is shown in Figure 1 .

These results show a polyphyletic Dendrobiinae with: (i) Dendrobium section Oxystophyllum deeply embedded within the strongly supported (100\% bootstrap support) Eriinae (Podochileae), (ii) a strongly supported (96\% bootstrap support) monophyletic Epigeneium sister to the remainder of the Dendrobiinae, and (iii) the remaining representatives of the Dendrobiinae separated into two major groups, the Australasian and Asian clades. Excluding Dendrobium section Oxystophyllum these results reveal only weak support ( $<50 \%$ bootstrap support) for the monophyly of the remainder of the ingroup including Epigeneium. Conversely there is moderately strong support for monophyly of Epigeneium, the Australasian (85\% bootstrap support) and Asian (91\% bootstrap support) clades. These results also show that the Dendrobieae is polyphyletic when the Bulbophyllinae is included, with the Eriinae (Podochileae) deeply embedded within it.

A more comprehensive molecular phylogenetic analysis was then undertaken based on the inclusion of an additional 52 species, mostly representative of the Asian clade from within the Malesian and Australasian regions, and in particular those attributed in the literature to Dendrobium section Pedilonum and associated taxa viz. sections Aporum, Calcarifera, Cuthbertsonia, Calyptrochilus, Dendrobium, Dolichocentrum, Oxyglossum and Rhopalanthe. This analysis, based on an alignment of 768 nucleotide sites of which 444 were potentially parsimony-informative, produced 122 equally parsimonious trees; tree length $=2726$; consistency index $(\mathrm{CI})=0.3899$; retention index $(\mathrm{RI})=0.6719$; and rescaled consistency index $(\mathrm{RC})=0.2620$. Successive weighting was then applied resulting in three trees, all with the same general topography. One randomly selected tree is shown as a phylogram in Fig. 2 . These results again show the polyphyletic condition of the Dendrobiinae and its fragmentation into two separate component groups, the larger of which is only weakly supported by both nuclear and plastid molecular analyses but contains three major, well-supported clades. Dendrobium section Oxystophyllum with Epigeneium remain isolated from the main body of the Dendrobiinae. Some of the species that were added in the more comprehensive analyses (Winika cunninghamii, Cannaeorchis fractiflexa, Dendrobium 


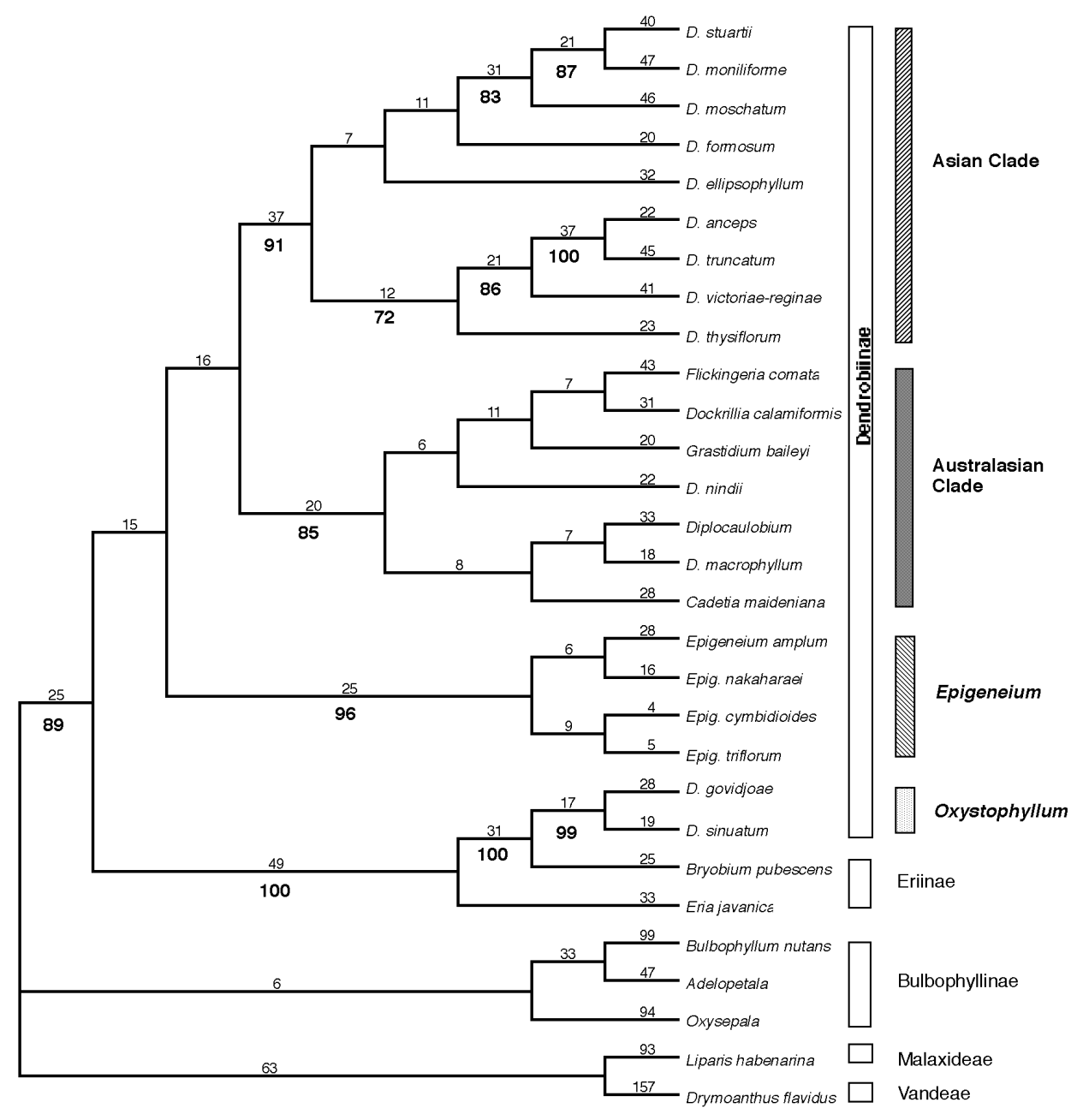

Fig. 1. One of three most parsimonious trees generated from the broad based data matrix based on nuclear ITS sequences, showing the composition of the Dendrobiinae with Oxystophyllum, Epigeneium and Australasian and Asian clades identified relative to 7 outgroup species: L. $=1440$, $\mathrm{CI}=0.5743, \mathrm{RI}=0.4853$. Numbers above branches are branch length estimates (ACCTRAN optimalization); bootstrap percentages greater than $50 \%$ are given below in bold. 


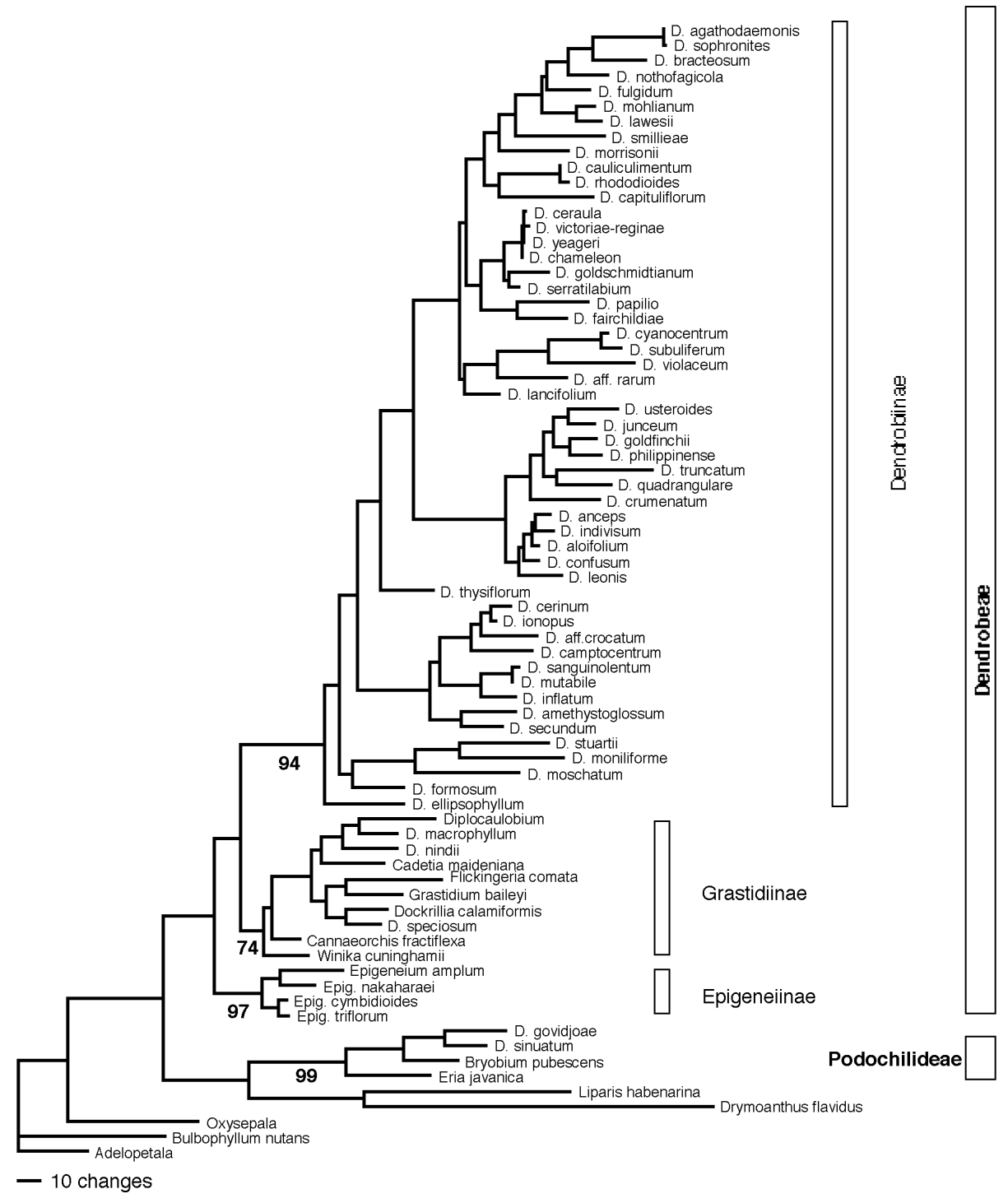

Fig. 2. A phylogram of one of the three most parsimonious successively weighted trees from the ITS analysis of a study of the Dendrobiinae and outgroup taxa based on 75 species: $L=2728$, $\mathrm{CI}=0.3897, \mathrm{RI}=0.6715$, showing the relationships between groups when all study species are included. Bootstrap percentages (50\% or more) for the four main taxa containing elements of the Dendrobiinae are in bold. 


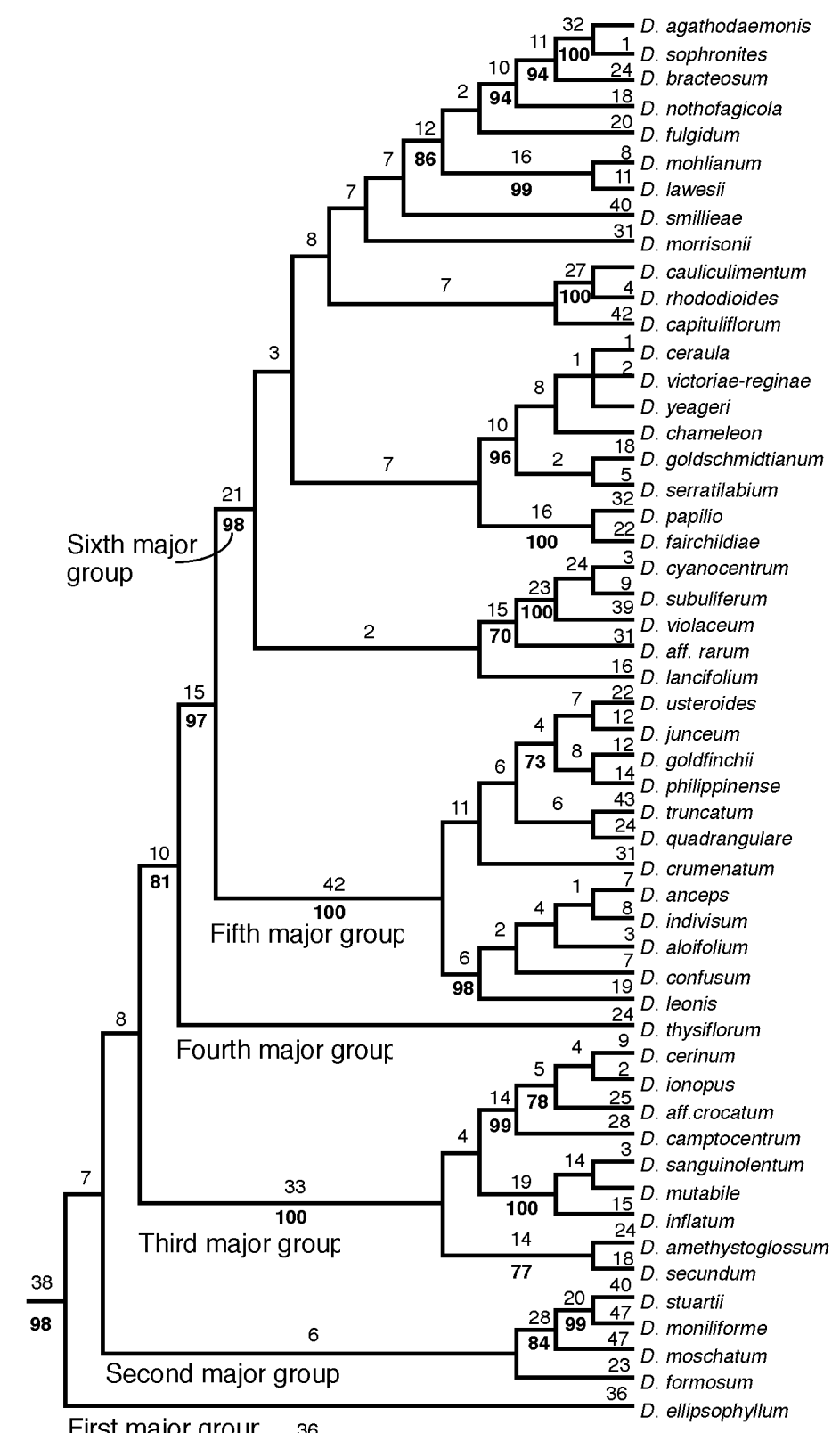

First major grouk 36

\section{Oxyglossum \\ Pedilonum \\ $\prod$ Calyptrochilus \\ Pedilonum}

Calcarifera

Pedilonum

Calcarifera

- Dolichocentrum

Calcarifera

Oxyglossum

- Pedilonum

Holochrysa

Rhopalanthe

․ Bolbidium

Rhopalanthe

Aporum

Callista

Calcarifera

Platycaulon

Calcarifera

Pedilonum

Dendrobium

ㅁormosae

Distichophyllum

Fig. 3. Details of the Asian clade portion of Fig. 2 showing one of the 3 most parsimonious successively weighted trees from the ITS analysis of the Dendrobiinae, and proposed arrangement of the six major groups within: $\mathrm{L}=2728, \mathrm{CI}=0.3897$, $\mathrm{RI}=0.6715$. Sections in which species have historically or are currently placed are shown on the right hand side column. Numbers above branches are branch length estimates (ACCTRAN optimalization); bootstrap percentages greater than $50 \%$ are given below in bold. 
nindii, D. macrophyllum and D. speciosum), group with Cadetia, Diplocaulobium, Dockrillia, Flickingeria and Grastidium into the moderately supported Australasian clade (74\% bootstrap support) thus rendering Dendrobium in its current interpretation, polyphyletic. All remaining species cluster into a strongly supported monophyletic Asian clade (94\% bootstrap support) also shown in Figure 3. Within the Asian clade there are six major groupings. The first contains a single species Dendrobium ellipsophyllum representative of section Distichophyllum. The second major group contains representatives of section Formosa and section Dendrobium including D. moniliforme, the designated type of the genus. All four remaining major groups are all clearly isolated and strongly supported (81-100\% bootstrap values) from each other. The third major group contains representatives of sections Pedilonum, Calcarifera and Platycaulon while the fourth major group contains a single species D. thysiflorum representative of section Callista. The fifth and sixth major groupings are grouped together with strong support ( $97 \%$ bootstrap value). Representatives of sections Aporum, Bolbidium and Rhopalanthe comprise the fifth major group. The sixth major group comprises a large assemblage of species, most of which have been assigned to section Pedilonum or the allied sections Calyptrochilus, Calcarifera and Oxyglossum, in addition to representatives of section Dolichocentrum. These results reveal the nonmonophyletic nature of many sections within this part of the Dendrobiinae but in particular, sections Calcarifera and Pedilonum. Additionally, section Rhopalanthe is paraphyletic with a representative of section Bolbidium embedded within it. Section Oxyglossum is polyphyletic whereas section Aporum represents a monophyletic group.

\section{Discussion}

These current analyses, based on ITS nrDNA sequence data, provide an insight into the phylogeny and overall structure in the Dendrobieae including a significant portion of the Dendrobiinae, in particular the Malesian elements of the Asian clade. At the broader level, using a similar range of species to that used in previous molecular systematic studies (Yukawa et al. 1993, 1996a, 1996b, 2000), the present results strongly corroborate the overall phylogeny of the Dendrobiinae based on analyses of plastid DNA data (restriction sites and $r b c \mathrm{~L}$ and matK sequences). Both sets of results show representatives of Epigeneium grouped together in a strongly supported clade (96-100\% bootstrap support) and sister to the remainder of the Dendrobiinae. They also show the remainder of the Dendrobiinae split into the same two major groupings, the Australasian and Asian clades. The strong correlation between both sets of results suggests the taxonomic status of this group needs reconsideration. On the basis of both independent sets of results the continued recognition of Epigeneium in a separate genus would seem appropriate.

\section{Dendrobium section Oxystophyllum}

Of particular note in these ITS sequence analyses is the grouping of Dendrobium govidjoae and D. sinuatum with Eria javanica and Bryobium pubescens, two representatives of the Eriinae (Podochileae). Dendrobium govidjoae and D. sinuatum are members of the taxon Dendrobium section Oxystophyllum and this group historically has been treated either as a separate genus Oxystophyllum (Blume 1825, Lindley 1830), as a section of Dendrobium (Miquel 1859, Smith 1908, Kraenzlin 1910, Schlechter 1912), or as a section of the genus Aporum (Reichenbach 1861, Hooker 1890, Brieger 1981) all within the tribe Dendrobieae, subtribe Dendrobiinae. When treated within Dendrobium, section Oxystophyllum has been interpreted as allied to sections Aporum and Rhopalanthe (Schlechter 1912) on account of similarities of vegetative features most 
notably the equitant leaves and the abbreviated, lateral inflorescences formed in the axils of the leaf-sheaths along the leafy part of the stem. The position of Oxystophyllum outside the Dendrobieae renders that tribe polyphyletic unless the Eriinae is included within it. Additionally, inclusion of Oxystophyllum within the Eriinae contradicts the interpretation that possession of eight pollinia can be used as a defining character for that subtribe (Dressler 1993). Careful examination of Dendrobium govidjoae and $D$. sinuatum plus other species in the group, both as living or herbarium specimens, reveals the existence of key morphological characters that correlate with, and support, the proposed alignment with the Eriinae rather than with the Dendrobiinae. Characters possessed by $D$. section Oxystophyllum include: pensile habit; roots wiry, hirsute, rusty brown, with a purplish growing apex; leaves equitant, rigid, falcate to lanceolate, with abscission layer towards base, apex sharply acute and with vascular traces confined to adaxial surface; inflorescences compressed, simple or compound, indeterminate, lateral or terminal, racemes, covered with persistent equitant, imbricate bracts, the solitary flowers arising intermittently; flowers sombre coloured, with short, acute, thick, rigid tepals, lateral sepals contiguous and adnate to column-foot, saccate; labellum ligulate, on a short hinge, thick, fleshy and secreting sticky fluids at base; pollinia four, in two separate sets of two, small, irregularly shaped, pinkish cream, and with prominent caudicles. Two of these characters in particular (the roots, wiry, hirsute, rusty brown, with a purplish growing apex; and the pollinia, with prominent caudicles) are more consistent with those present in various members of the Eriinae than with those in the Dendrobiinae. Although unusual in the Eriinae, the equitant leaf habit is present in Eria section Aporodes (Schlechter 1912, Cootes 2001), another example of convergent evolution within the Orchidaceae. Aside from the obvious similarities of habit and vegetative morphology, characters possessed by species in $D$. section Aporum are: roots white or green, thin, glabrous; vascular traces scattered randomly throughout the leaf tissue; compressed simple or compound inflorescence lacking; bracts equitant, imbricate, persistent; flowers with a well defined columnfoot; labellum non-articulate, lacking any secretory processes; pollinia yellow, four in two tightly appressed hemi-pollinia lacking caudicles. On the basis of these ITS sequence analyses and the cited morphological characters, it is proposed that Oxystophyllum as originally interpreted by Blume (1825), should again be recognized at generic rank within the subtribe Eriinae (Podochilideae) rather than in the Dendrobieae (see below). Additionally, the definition of the Eriinae should be adjusted to include: pollinia, eight (rarely four) in two sets of four (two), with caudicles.

\section{Epigeneium}

Although there is strong support for the monophyly of Epigeneium (96\% bootstrap support) in the present ITS analyses, there is only weak support for its position as sister group to the remaining members of the Dendrobiinae, a result that was also found in analyses of $r b c \mathrm{~L}$ and $m a t \mathrm{~K}$ sequences and cpDNA restriction sites (Yukawa et al. 1993, 1996a, 2000). Treatment of the group as part of, but sister to, the bulk of the Dendrobiinae is not unreasonable (see below). Many species in this group were first treated under the epithet Sarcopodium Lindl. (Lindley 1850, Rolfe 1910, Kraenzlin 1910) or as a section of Dendrobium (Hooker 1890, Schlechter 1912), based on Dendrobium amplum. However, none of these authors was apparently aware that the name Sarcopodium was a later homonym of a fungal genus. Later Gagnepain (1932) described Epigeneium to accommodate a small group of morphologically distinct Dendrobium species typified by D. fargesii, because of their Bulbophyllum-like habit but having flowers reminiscent of a Coelogyne. Because of the unavailability of the name Sarcopodium, Hawkes (1956) proposed the alternative name Katherinea, overlooking, or not making the connection to, the earlier published legitimate name Epigeneium. The name Epigeneium has since been taken up and applied, using a broader 
circumscription, to all species in the group (Summerhayes 1957, Seidenfaden 1980, Garay \& Romero-Gonzalez 1999) although some authors prefer to maintain the distinction between Epigeneium and Katherinea (Balakrishnan \& Chowdhury 1966). Based on detailed morphological study of both living and herbarium material, species in the Epigeneium clade can be circumscribed by the following combination of characters: plants epiphytic or lithophytic; stems rhizomatous terminating in a single internode pseudobulb; leaves conduplicate, coriaceous, 1-3, terminal; inflorescence subterminal, determinate, single or multi-flowered, erect or pedant, arising from a prominent erect, imbricate bract; flowers long-lasting, with spreading segments, nonarticulate labellum, a prominent long column-foot, petals obliquely attached for greater part or not, glabrous elongate column, with prominent apical often ornate anther attachment (see below).

In addition, there are three well-supported, morphologically distinct groups within the Epigeneium clade. These three taxa, represented in Figure 1 by (a) E. nakaharaei, (b) E. amplum, and (c) E. cymbidioides and E. triflorum, more or less correspond to those identified as sections by Garay and Romero-Gonzalez (1999), viz E. section Epigeneium, $E$. section Katherinea and E. section Racemosum. Briefly these are characterised as follows:

(a) section Epigeneium: epiphytic herb with reptant habit; stems pseudobulbous, pseudomoniliform, terminated by solitary leaf; inflorescence one-flowered, arising from new growth, shorter than leaves; dorsal and lateral sepals well separated and petals obliquely attached for greater part along a prominent long column-foot that is 2-3 times longer than the broadly concave column.

(b) section Katherinea: epiphytic herb with Coelogyne-like habit; stems rhizomatous terminating in erect, pseudobulbs; leaves erect, two to three per pseudobulb; inflorescence one-flowered, arising only from old growth, shorter than leaves; flowers large, Coelogyne-like; column approximately equal to the column-foot; column-foot porrect, narrow.

(c) section Racemosum: epiphytic herb often in large clumps; stems rhizomatous, often markedly so, terminating in suberect to ascending, pseudobulbs; leaves two or three per pseudobulb erect or spreading; inflorescence racemose, terminal to subterminal, multi-flowered, erect to pendulous, commonly much exceeding the leaves; flowers stellate, the lateral sepals not joined at base and labellum contiguous with columnfoot; column narrowly concave approximately equal to the column-foot; a porrect, narrow column-foot.

In addition to highlighting the isolation of the Epigeneium clade as distinct from the remainder of the Dendrobiinae, results from these ITS analyses also provide a basis for alternative interpretations on the taxonomic status of the three identified groups within the clade. Since the whole group is monophyletic, one option is to maintain all three groups as a single genus under the name Epigeneium in line with the proposal of Garay and Romero-Gonzalez (1999). Another equally plausible and tempting option is to recognise all three sections at generic rank. There is, however, a problem with this option. Epigeneium section Racemosa is typified by E. acuminatum for which no material was available for sequencing. Without ITS sequence data it would be presumptive to suggest that Epigeneium section Racemosa, based only on study of E. cymbidioides and E. triflorum, represents a monophyletic taxon. One unacceptable option, based on these ITS sequence analysis results, is the recognition of just two genera in the group, as proposed by Balakrishnan and Chowdhury (1966), because acceptance of section Katherinea at generic rank would render Epigeneium paraphyletic. On the basis of all available evidence (and recognising that further research is require) for the present it is proposed to recognise only Epigeneium within the Epigeneiinae. 
This leaves the remainder of the Dendrobiinae spread amongst the relatively strongly supported Australasian and Asian clades, a situation consistent with the results based on $r b c \mathrm{~L}$ and matK sequence and plastid restriction site analyses (Yukawa et al. 1996, 2000). Several taxonomic options are apparent; the status quo.unfortunately is not one of them.

\section{Australasian clade}

Focusing firstly on the Australasian clade in results from the present ITS analyses, the presence of the long-accepted, established genera Cadetia, Diplocaulobium and Flickingeria, deep within the well-supported Australian clade (85\% bootstrap support), renders the current concept of the genus Dendrobium polyphyletic.

Cadetia was first described by Gaudichaud (1826) but it was Schlechter (1912) who finally established its status as distinct from Dendrobium. He characterised Cadetia by the possession of: the Pleurothallis-like habit; formation of a spur through cohesion anteriorly in the lower half of the lateral sepals; papillae in front of the column and labellum.

Since its proposal as a genus Diplocaulobium (Kraenzlin 1910) has gradually gained acceptance as separate from Dendrobium based on possession of the following characters: closely spaced single internode pseudobulbs; flowers mostly solitary, pedicellate, arising from a conspicuous bract at base of single terminal leaf, stellate, flowers lasting one day (rarely longer), with distinct mentum and articulate labellum (Lavarack et al. 2000)

Flickingeria, which was originally described under the illegitimate name Desmotrichum (Blume 1825), has similarly regained acceptance as a separate genus having in the interim been treated as a section of Dendrobium (Schlechter 1912) and under the generic name Ephemerantha (Hunt \& Summerhayes 1961). The genus Flickingeria is characterised by: rhizomes irregularly branched, creeping, terminating in an erect pseudobulbous internode with a terminal non-sheathing leaf; inflorescences single or multi-flowered, terminal or subterminal to pseudobulb, both adaxial and abaxial to leaf, and covered by persistent sheathing bracts; flowers ephemeral; labellum midlobe fimbriate plicate, or bilobate (Seidenfaden 1980) Since the type species for Dendrobium is embedded within the Asian clade, one option is to accept that all species in the Australasian clade are representatives of genera other than Dendrobium. A second option is to re-include Cadetia, Diplocaulobium and Flickingeria in a broadly defined Dendrobium that includes both the Australian and Asian clades. However, there is only very weak support from the present analyses for treating the Australasian and Asian clades together as one large monophyletic group, and including these wellestablished, morphologically well-defined genera in an extremely broad concept of the genus Dendrobium would lead to much confusion and be unpopular with users. It would also leave Dendrobium as a huge (c. $1800 \mathrm{spp}$ ) unwieldy genus. A third option, to treat the Australasian and Asian clades as two separate genera, is likewise unhelpful. Such a proposal requires, in the case of the Australasian clade, the reduction of Cadetia, Diplocaulobium and Flickingeria, as well as all other members of this clade, to synonyms of the morphologically disparate and distinct Grastidium (Blume, 1825), as it represents the oldest named genus in the clade.

As shown previously, Grastidium is easily separated from other Dendrobiinae by the possession of: laterally flattened stems of pseudo-indeterminate growth; synchronous flowering; lateral inflorescences emerging from a node opposite a leaf lamina and breaking through its subtending sheath; inflorescences emerging with the protection of two indurated, laterally compressed sheathing bracts; inflorescence a much reduced, geminate raceme with terminal, inward-facing flowers; flowers ephemeral (Clements \& Jones 1997). These characters, or combinations thereof, are also absent 
from the remaining species in the Australasian clade and the aggregation of all species into a single genus under the name Grastidium would create more confusion and uncertainty than presently exist. Yukawa et al. (1993) arrived at similar conclusions with respect to the integrity and maintenance of representatives within the Australasian clade (including the genera Cadetia, Diplocaulobium and Flickingeria) although they refrained from formally recognising any other genera in the clade. Taxonomic and systematics treatments of most taxa within the Australasian clade are already well-advanced with the recognition of 35 genera:

\begin{abstract}
Abaxianthus M.A.Clem. et D.L.Jones (Clements \& Jones 2002), Australorchis Brieger (Brieger 1981), Bouletia M.A.Clem. et D.L.Jones (Clements \& Jones 2002), Cadetia Gaud. (Schlechter 1912), Cannaeorchis M.A.Clem. et D.L.Jones (Clements \& Jones 1998b); Cepobaculum M.A.Clem. et D.L.Jones, Ceratobium (Lindl.) M.A.Clem. et D.L.Jones, Davejonesia M.A.Clem, Dendrobates M.A.Clem. et D.L.Jones (Clements \& Jones 2002), Dichopus Blume, Diplocaulobium (Rchb.f.) Kraenzl. (Kraenzlin 1910), Dockrillia Brieger (Clements \& Jones 1996), Durabaculum M.A.Clem. et D.L.Jones, Eleutheroglossum (Schltr.) M.A.Clem. et D.L.Jones (Clements \& Jones 2002), Eriopexis (Schltr.) Brieger (Brieger 1981, Clements \& Jones 1997), Euphlebium (Kraenzl.) Brieger (Brieger 1981), Exochanthus M.A.Clem. et D.L.Jones (Clements \& Jones 2002), Flickingeria A. Hawkes (Seidenfaden 1980), Grastidium Blume (Clements \& Jones 1997), Herpethophytum (Schltr.) Brieger (Brieger 1981), Inobulbum (Schltr.) Schltr. et Kraenzl. (Clements \& Jones 1998a), Kinetochilus (Schltr.) Brieger (Brieger 1981), Leioanthum M.A.Clem. et D.L.Jones (Clements \& Jones 2002), Microphytanthe (Schltr.) Brieger (Brieger 1981), Monanthos (Schltr.) Brieger (Brieger 1981), Sarcocadetia (Schltr.) M.A.Clem. et D.L.Jones (Clements and Jones 2002), Sayeria Kraenzl. (Rauschert 1983), Stelbophyllum M.A.Clem. et D.L.Jones, Tetrabaculum M.A.Clem. et D.L.Jones (Clements and Jones 2002), Tetrodon (Kraenzl.) M.A.Clem. et D.L.Jones (Clements \& Jones 1998a), Thelychiton Endl. (Clements and Jones 2002), Trachyrhizum (Schltr.) Breig. (Brieger 1981), Tropilis Raf. (Rauschert 1983, Clements and Jones 2002), Vappodes M.A.Clem. et D.L.Jones (Clements and Jones 2002) and Winika M.A.Clem., D.L.Jones et Molloy (Clements et al. 1997).
\end{abstract}

A full account of the phylogeny of these taxa based on the results of molecular analyses is in preparation. The present ITS sequence analyses, and the plastid DNA analyses of Yukawa et al. (1996, 2000), also provide a basis for the recognition of both the Australasian and Asian clades at higher taxonomic rank within the Dendrobieae (examined below).

\title{
Asian clade
}

The remaining element of the Dendrobiinae, the Asian clade, forms a strongly supported monophyletic group ( $94 \%$ bootstrap support value), which strongly correlates with the results of Yukawa et al. (1996, 2000). Presence of Dendrobium moniliforme, the designated type species for the genus Dendrobium (Holttum et al. 1982) automatically means that in any classification system this clade must be included within the Dendrobiinae. Focussing on the elements of this clade, there are three strongly supported major groupings, all with $98-100 \%$ bootstrap support values, as well as two isolated species and another major group that contains D. moniliforme. Once again, although the species used in this study are not fully representative of all the groups considered to make up the Asian clade, they nevertheless provide an insight into the phylogeny of the group as a whole and in particular many of the Malesian elements of the Dendrobiinae with emphasis on representatives of Dendrobium section Pedilonum.

First major group: The first major group comprises a single species Dendrobium ellipsophyllum, that historically has been treated as: part of Dendrobium subgenus Dendrobium (Lindley 1851, Smith 1905); in section Chrysantha (Reichenbach, 1861); in section Revoluta; in subgenus Grastidium (Kraenzlin 1910); but more typically in section Distichophyllum (Hooker 1890, Schlechter 1912, Seidenfaden 1985, Brieger 1981). Hooker (1890) established section Distichophyllum to accommodate those species with 
the habit of the genus Appendicula and flowers solitary or in short leaf-opposed racemes, a short, spur-like mentum as long as, or longer than, the lateral sepals and with broad recurved side lobes. Despite the taxon being represented by a single species in the present ITS sequence analyses (in order to keep a direct compatability with the species used by Yukawa et al. (1993)), the isolation of D. ellipsophyllum from the other major groups supports it recognition as a distinct from Dendrobium sens. str. Sequence analyses of other species from within the group, D. austrcaledonicum, D. revolutum, and D. aff. sculptum, are in progress. Examination of fresh and herbarium material of $D$. section Distichophyllum, including many type collections, has revealed additional key characters to those cited above present in all species in this taxon. Key characters for the taxon are: stems slender non-pseudobulbous, often angular; leaves pedicellate and clasping; inflorescence a highly reduced, lateral periodically developing raceme; flowers solitary (rarely two), each with a papery sheath that persists in the sheathing bracts after anthesis; labellum trilobed, with broadly bilobed mid-lobe, fleshy, minutely papillate and spongy at base on lamina callus, forming a closed, conspicuous, nectiferous spur with basal half to the column-foot; column with centra groove; column-foot concave, papillose on inner surface; and protocorm discoid type. On the basis of these broader results this taxon has been recognised as a distinct genus and given the name Distichorchis (Clements \& Jones 2002).

Second major group: The type species for the genus Dendrobium together with D. formosum, D. moschatum and D. stuartii, are contained within the second major group but there is only weak support $(<50 \%$ bootstrap support) for its acceptance as a monophyletic taxon. Internally however, there is good support for separation of D. formosum from the remaining species in the group. Dendrobium formosum belongs to a group commonly referred to as section 'Nigrohirsutae' on account of possession of black hairs on the leaf sheaths of most species (Lindley 1859), but correctly the sectional name Formosae should be applied to it (Seidenfaden 1985). Authors such as Lindley (1859) and Reichenbach (1861) treated D. formosum and morphologically similar species belonging to section Dendrobium, in the subgenus Nigrohirsuta (Kraenzlin 1910), or in section Oxygenianthe (Schlechter 1912). However, not all species currently placed within D. section Formosae (e.g. Seidenfaden 1985, 1992, Seidenfaden \& Wood 1992, Cootes 2001, Wood et al. 1993, Wood \& Cribb 1994, Lavarack et al 2000, Comber 2001) possess the characteristic black hairs on the leaf sheaths, which suggests that further research is required as the taxon may not be monophyletic. The phylogeny and systematics of the group will be the subject of a separate paper. The remaining species in the second major group have historically been included in $\mathrm{D}$. section Eudendrobium (Lindley 1851, Bentham \& Hooker 1883, Kraenzlin 1910), section Planifolia (Reichenbach 1861), but more recently been treated as members of $D$. section Dendrobium (Seidenfaden 1985) although the nomenclatural history, taxonomy and systematics of the group is very complex and will be the subject of a separate paper. Representatives of this taxon are particularly scarce towards the eastern part of the Malay archipelago and in New Guinea are represented by three species and in Australia by a solitary species, $D$. stuartii.

Third major group: The third major group contains $D$. secundum, the designated type of the genus Pedilonum, plus eight other species representative of sections Calcarifera and Platycaulon of Dendrobium (Smith 1908, Schlechter 1912). Other species representative of Pedilonum are, however, scattered amongst three separate subclades in the sixth major group of the ingroup. This renders Pedilonum polyphyletic in any traditional or modern sense with the bulk of representative species well removed from D. secundum. Additionally, the proposed arrangement of species bears little relationship to any proposed infrageneric classification of the Dendrobiinae, which has been based on perceived differences in floral morphology. Sister to D. secundum, and with moderately strong bootstrap support, is D. amethystoglossum. This proposed 
arrangement of these two species seems unusual; firstly, because of the presumed lack of similarity of the two species, and secondly, because historically the possibility has barely been considered. For example, Kraenzlin (1910) included D. amethystoglossum with 28 other species, in the subgenus Pedilonum section Glomerata subsection Mesocentra, whereas D. secundum was treated in the adjacent section Secunda in subgenus Pedilonum. Other authors such as Schlechter (1912), Brieger (1981), Rauschert (1983) and Seidenfaden (1985), did not offer an opinion on the phylogenetic position of D. amethystoglossum. By comparison, Cootes (2001) in the latest account of the orchids of the Philippines, and Comber (2002), treat the endemic $D$. amethystoglossum as a member of $D$. section Calcarifera. On my examination it was found that $D$. secundum and $D$. amethystoglossum shared several morphological features in particular: stems erect or porrect, pseduobulbous, soft, fleshy, long and tapering, covered with leaf sheaths; leaves thin, fleshy, deciduous, the sheath persistent and with slightly thickened red veins; lateral sepals connate in basal half, forming a saccate spur; labellum non-articulate, long, narrow, rigid, with median cross-laminar ridge or spur and concave in basal half forming a nectary with concave column foot and connate lateral sepals; rostellum protruding, acute and rigid; pollinia oblong-orbicular, bright yellow. Other species in this major grouping cluster into two separate clades. One contains D. inflatum, D. mutabile and D. sanguinolentum while the second comprises $D$. camptocentrum, D. aff. crocatum, D. ionopus and D. cerinum. Apart from $D$. platygastrium, all the other species have been treated as part of the poorly understood and often overlooked D. section Calcarifera (Smith 1908, Comber 1990, 2001, Lavarack et al. 2000), which is characterised by possession of flowers with a long mentum directed away from the pedicel and ovary; a moderately wide labellum that narrows abruptly towards the base where adnate to the column foot for most of its length and with a small protuberance on the upper surface. In comparison, although superficially florally similar D. platygastrium is a member of section Platygastrium, so called because of the characteristic flattened, compressed pseudobulbs. There is an historical link within this entire major grouping.

Blume (1825) when describing Pedilonum considered it distinct from Dendrobium by the absence of an articulate labellum and with flowers with a slipper shaped labellum, dividing the six species in the genus into two sections. The second of these two sections which was distinguished by lateral sepals forming an elongate spur often adnate to the labellum claw, contains $P$. secundum as well as P. undulatum, P. biflorum and P. erosum. Two of these species, P. undulatum (as D. hymenophyllum) and P. biflorum (as D. gemellum), have since been transferred to Dendrobium and are now treated as members of section Calcarifera (Comber 1990, 2001) so Blume's interpretation of presumed relationships between this group of species perhaps has some basis. Blume (1825) also described Onychium lamellatum, with its characteristic laterally flattened pseudobulbs. This species has since been transferred to Dendrobium (Lindley, 1830) as well as designated as the type of Dendrobium section Platycaulon (Schlechter 1905), with close affinities to section Eugenanthe (Schlechter 1912) Opinions are divided on how to treat this group of species. It has been variously maintained in $D$. section Platycaulon (Kraenzlin 1910, Comber 1990, 2001, Lavarack et al. 2000), in D. section Calcarifera (Wood \& Cribb 1994), transferred the genus to Pedilonum (Brieger 1981), or incorporated within D. section Pedilonum (Seidenfaden 1985, 1992, 1997, Seidenfaen \& Wood 1992). Comber (2001) recently suggested that the only difference between $D$. lamellatum and species in section Calcarifera is the vegetative character of flattened stems. In these ITS sequence analyses D. platygastrium groups with species possessing flowers with a long narrow mentum that is adnate to the column foot in the basal half, rather than those species with a similarly inflated mentum and labellum attached only at the base of the column foot. Dendrobium platygastrium and its relatives also lack any form of basal protuberance on the labellum. Presence of a representative of this section 
in this clade does, however, render section Calcarifera paraphyletic. All these data provide a framework for the recognition of the separate sections Platycaulon-Calcarifera as distinct from the first group of section Calcarifera. Furthermore, whilst there is very strong support for these two individual Calcarifera groups $(100 \%$ and $95 \%$ bootstrap support), there is by comparison only poor support for the recognition of these two groups as sister taxa.

The remaining species in this major grouping, D. mutabile, D. sanguinolentum and D. inflatum, which have also been considered part of Calcarifera (Comber 2000), are clearly separated in a well-supported clade (100\% bootstrap support). Historically, these species were described by Blume (1825) in the illegitimate genus Onychium and then transferred to Dendrobium (Lindley 1830). Blume's description of Onychium agrees closely with Smith's concept of section Calcarifera and two of the species originally described in Onychium, namely O. mutabile and O. nudum (similar to D. inflatum), have since been transferred to this section. Characteristically, this group of species have flowers with an inflated spur; a more membranous labellum that is more or less continuous with the base of the column foot forming a short nectiferous spur; and uniformly obovate-elongate pollinia. Interestingly, the pollinia differ significantly from those found in representatives of the first described group in Calcarifera, where they are irregularly shaped, undulate structures. These data together suggest that Calcarifera is not a monophyletic group in its current form and that these various elements of the group are deserving of higher taxonomic status separate from that of Pedilonum.

Fourth major group: The fourth major group contains a single species, D. thysiflorum, representative of a group of species commonly referred to section Callista (Reichenbach, 1868, Schlechter 1912, Seidenfaden 1985) or as a separate genus Callista (Kraenzlin 1910, Brieger 1981) The genus Callista was described by Loureiro (1790) and predates Dendrobium by nine years. One consequence of the amalgamation of many genera into Dendrobium and recognition by Reichenbach (1868) that Callista was synonymous with it, was that by the rules of the International Code of Botanical Nomenclature (ICBN), Callista had priority over Dendrobium. It was on this basis that Kuntze (1891) automatically transferred most species described in Dendrobium to Callista. To counteract this, a decision was made at the Second International Botanical Congress to conserve Dendrobium. All of this of course is based on the assumption that Callista is part of Dendrobium, which is easy to understand considering the similarity of floral morphology between species in the two groups. However, on the basis of the results generated in these ITS studies, where Callista is separated from Dendrobium sens. str. by the third major group containing morphologically disparate species, it would appear that these perceived similarities are yet another example of convergent evolution within the Dendrobieae, or that the floral similarities are symplesiomorphic. Apart from floral morphology, Callista is characterised by the possession of erect, angular, fusiforme, pseudobulbous stems, coriaceous, terminal to subterminal leaves, and development of the inflorescence as though being extruded like paste from the original stem bud. Furthermore, in broader based studies the addition of sequences obtained from four morphologically similar species considered part of this group, D. amabile (the type species for Callista), D. griffithianum and D. palpebrae, confirmed the group was a strongly supported monophyletic taxon well isolated from $D$. section Dendrobium. The combined characteristics of Callista enunciated above coupled with its isolated position in these ITS sequence analyses results, provides good evidence that Loureiro's original concept should again be adopted.

Fifth major group: Species in the fifth major group form a strongly supported clade (100\% bootstrap support) isolated from the remainder of the ingroup. Within this major grouping are two subgroups, only one of which is strongly supported $(98 \%$ 
bootstrap support) In the strongly supported subgroup, D. leonis, D. aloifolium, $D$. indivisum and $D$. anceps have been treated by most authors as the genus Aporum (Blume 1825, Lindley 1830, 1847, Pfitzer 1889, Brieger 1981) or as section Aporum (Lindley 1851, Reichenbach 1861, Bentham \& Hooker 1883) or subgenus Aporum (Kraenzlin 1910) within Dendrobium. Dendrobium aloifolium was also originally described by Blume (1825) in the monotypic genus Macrostomium while D. anceps was treated as the type for another monotypic genus Ditulima (Rafinesque 1836). In contrast to these four species, D. confusum belongs to an assemblage of species treated under the sectional name Strongyle (Smith 1905, Seidenfaden 1985), first devised by Lindley (1851) to account for those species within Dendrobium possessing terete leaves. The similarities between species in section Aporum and Strongyle had been noted by Schlechter (1912) who treated the latter as a part of Aporum. Despite some diversity in the origins of the inflorescence and floral morphology, the group is held together on its vegetative characters, in particular: possession of equitant leaves; lack of any form of thickening of the ensheathed wiry stems; production of persistent, compact, lateral and terminal inflorescences with persistent indeterminate meristematic regions from which are generated single (occasionally multiple) flowers. Possession of these common characters and the fact that all these representative species are embedded within a single tight cluster suggests they should be treated as representative of a single taxon, the earliest and most commonly applied generic or sectional name being Aporum.

In the second (although poorly supported) subgroup within the fifth major group, all but $D$. quadrangulare have been treated either in the section or subgenus Crumenata (Pfitzer 1889, Kraenzlin 1910), or in the (more widely used name) section Rhopalanthe in Dendrobium (Schlechter 1912, Seidenfaden 1985), or as a component of Aporum (Brieger 1981). By comparison, Dendrobium quadrangulare is a representative of D. section Bolbidium (Schlechter 1912, Seidenfaden 1985). In Schlechter's system of classification of the Dendrobiinae, section Bolbidium was placed in the first subgenus Anthecebium well removed from the third subgenus Rhopalobium that contained D. crumenata. No species in this group has previously been considered to be closely related to section Pedilonum. Careful study of the two subgroups identified by these ITS sequence analyses reveals that although they appear to represent groups of species with different gross vegetative characteristics they nevertheless share many features. For example, the equitant leaf habit common to all species in the first subgroup, section Aporum, is also present in species such as D. goldfinchii and D. philippinense in the second subgroup. A persistent inflorescence covered in the persistent remains of successive floral bracts, and containing an indeterminate meristem that permits the successive production of flowers from the same point on the stems, is however common to all species in the fifth major group. All species in the second, poorly supported subgroup are also united by the common possession of one to several swollen, near-basal, leafless internodes. For those representative species possessing one to several swollen, near basal leafless internodes, the vegetative form varies from the crassulate duplicate two leaved form found in Bolbidium, to the conduplicate thin leaves of D. truncatum, the thicker multi-leaved stems of D. crumenatum, the rigid, terete leaves of D. junceum and D. usteroides, to the flattened equitant leaves of D. goldfinchii and D. philippinense. Possession of these features was also noted previously when Loureiro (1790) described Ceraia simplissisima, which predates the description of Dendrobium by nine years.

Although the type specimen of Ceraia simplissisima now lacks any floral material, it is undoubtedly representative of a group of species similar to D. crumenatum. Brieger (1981) recognised these differences as significant and raised the taxon to generic rank. Schlechter (1912) also created the solitary section Rhopalanthe in his subgenus Rhopalobium within Dendrobium, for those species with pseudobulbs or stems 
thickened on 1-3 internodes only. In so doing he recognised its affinities with Aporum and proposed the subsection name Aporopsis to accommodate the species with equitant leaves that he was about to describe as distinct from $D$. crumenatum (which has conduplicate leaves and undoubtedly considered by him typical of the subgenus). The affinities of vegetative morphology aside, species in the whole group are characterised by the near-membranous flowers which last only one to several days and synchronous flowering habit; the broad, membranous, concave column foot, very short column, and the thin, spreading labellum with a broadly lobed apex. Also embedded within this general group is D. quadrangulare, which is representative of $D$. section Bolbidium (Lindley 1850), D. subgenus Bolbidium (Kraenzlin, 1910 (although he included a large number of Cadetia species in the taxon)), D. subgenus Athecebium section Bolbidium (Schlechter 1912) and Bolbidium (Brieger 1981). With Bolbidium embedded deeply within the whole group, Schlechter's concept of subgenus Rhopalobium is rendered paraphyletic. Recognition of Bolbidium at the generic rank, such as has been proposed by Brieger (1981), would seem premature on the basis of these ITS sequence analyses results. If additional studies using a greater range of species representatives of the various groups were to establish that Bolbidium needed to be treated as a separate genus, it would necessitate the acceptance of at least three other genera including Ceraia. If we apply a broader generic concept to this group as a whole, then the first available name is Ceraia, despite the uncertainties surrounding the determination of the species described as the type. Either scenario necessitates the rerecognition of the genus Ceraia, as distinct from Dendrobium, something both the molecular results and morphological data strongly support. There is one further piece of information concerning the group as a whole. All species in this major group, studied to date, including those referred to the subgroup Aporum, are also defined by possession of an isobilateral protocorm (Clements 2000), a feature known to be absent from the remainder of the Asian clade. Although further research is clearly needed using a greater range of species, possession of the defining characters and isolation of the group in these ITS results, provides a strong basis for the re-instatement of the group as a whole and recognition of at least two genera therein.

Sixth major group: The sixth major group is strongly supported (99\% bootstrap support) and represents a complex of taxa with many different vegetative and floral forms. Historically most species in the complex have been placed in at least ten different infrageneric taxa within Dendrobium, including section Pedilonum or those sections considered closely related to it, e.g. Calyptrochilus, Cuthbertsonia and Oxyglossum (Schlechter 1912, Brieger 1981, Reeve \& Wood 1989). Since the type of Pedilonum (D. secundum) is isolated in the third major group in these analyses, it is apparent that Pedilonum as taditionally defined, is entirely artificial. Isolated at the base of the sixth major group is a clade containing D. lancifolium. This species is characterised by possession of a cluster of thin stems with lanceolate, grape-like leaves and has short lateral or terminal inflorescences of one to a few pink flowers. It has variously been included in section Chrysantha (Reichenbach 1861), subgenus Pedilonum section Glomerata and subgenus Grastidium section Revoluta (Kraenzlin 1910), or section Calcarifera (Schlechter 1925, van Bodegom 1973, O’Byrne 2001, Cootes 2001) of Dendrobium. Reichenbach's section Chrysantha is a renamed and expanded version of the ill-defined and often overlooked Dendrobium section Holochrysa of Lindley (1859). Dendrobium section Holochrysa was first described to accommodate a small group of Indian species with 'stems on all sides leafy and flowers entirely yellow' but Reichenbach expanded its limits to cover many more species including D. lancifolium which has pink and white, rather than yellow, flowers. Most subsequent authors have never seriously considered using Reichenbach's system of classification for Dendrobium because it is confusing (Seidenfaden 1985). Kraenzlin (1910), in his much critised monograph of the Dendrobiinae, was clearly confused about the 
relationship of D. lancifolium as he simultaneously included it as 'Species dubia' under D. subgenus Pedilonum section Glomerata and then again in D. subgenus Grastidium section Revoluta. Both taxa are highly artificial, containing species that, in more modern accounts of Dendrobium, are treated in many different taxa including some that are now recognised as representative of distinct genera such as Grastidium sens. str. (Clements \& Jones 1998) and Cannaeorchis (Clements \& Jones 1999). The nonmonophyletic nature of section Calcarifera has been dealt with above and the isolation of the D. lancifolium group from those in the third major group in the present ITS results provides further evidence of the artificiality of that taxon. The isolation of D. lancifolium from any other subgroups of species in this major group suggests it should be recognised as a separate genus or infraheneric taxon,but further study is required. Clustered with $D$. lancifolium is D. aff. rarum from Vanuatu, a representative of section Pedilonum, and three species representative of D. section Oxyglossum (Schlechter 1912). Reeve and Woods (1989), in their revision of the group considered species belonging to sections Oxyglossum and Cuthbertsonia, on account of the overall similarity of floral features, should be amalgamated into a single taxon under the name $D$. section Oxyglossum. Results from the present ITS studies reveal the exact opposite, where D. sophronites and D. agathodaemonis are present in another arm of the sixth major group, rendering Reeve and Woods' concept of section Oxyglossum polyphyletic. There is, however, strong ITS and morphological support for the monophyly of the Oxyglossum group for which D. cyanocentrum is the type. These species are readily recognised by possession of short tapering pseudobulbs with a few terminal to subterminal leaves, and one- to multi-flowered inflorescences, multiribbed ovaries, and flowers with acute to acuminate segments including the labellum. In comparison, species in the Cuthbertsonia group possess, amongst other things, flowers with an obtuse labellum apex. Dendrobium aff. rarum possesses some floral features common to those found in section Oxyglossum, but differs in plant habit where the elongate, thinly pseudobulbous stems are semi-pendulous. The weak-moderate level of support for the inclusion of $D$. aff. rarum into section Oxyglossum suggests this presumed relationship needs further investigation.

All remaining species in the sixth major grouping fall into two weakly supported clades (bootstrap values below 50\%), but with several strongly supported subgroups in each. The first of these weakly supported clades comprises D. fairchildiae, D. papilio, D. serratilabium, D. goldschmidtianum, D. chameleon, D. ceruela, D. yeageri and D. victoriae-reginae, in two strongly supported groups $(96 \%$ and $100 \%$ bootstraps values). Ames and Quisumbing (1932) in describing D. fairchildiae, placed it in section Calcariferaw while D. papilio has been considered to have affinities to section Virgatae (Ames 1908), subgenus Crumenata (Kraenzlin 1910), section Calcarifera (Lavarack et al. 2000), and section Dolichocentrum (Cootes 2001). Only the last of these proposals are supported on the basis of these ITS sequence analyses. As indicated above, section Calcarifera was created by Smith (1908), when describing D. pedicellatum, and this species equates to the clade containing D. mutabile, $D$. sanguinolentum and D. inflatum in the third major grouping of these results. The treatment of $D$. fairchildiae as a member of section Calcarifera renders that section polyphyletic in the present analysis, and the relationship is clearly artificial. Section Virgatae (Hooker 1885) and the subgenus Crumenata are both roughly equivalent to section Rhopalanthe of Schlechter (1912) and contain species grouped together in the fifth major group of these ITS analyses, rendering that taxon paraphyletic. Cootes (2001), in assigning D. papilio to section Dolichocentrum, relied heavily on the similarities in both vegetative and floral morphology to those of $D$. furcatum, the type of the taxon, in particular the thin wiry stems with grass-like leaves, elongate spur formed through fusion of the base of the lateral sepals. The furthur addition of the vegetative and florally similar species, D. auriculatum and D. miyasakii seems logical. On the basis of these ITS results, the 
treatment of section Dolichocentrum by Brieger (1981) as a separate genus seems premature and further research is needed to clarify its relationship with $D$. fairchildiae and similar species. A second strongly supported clade (96\% bootstrap support) accounts for all remaining species in this sub grouping, viz. D. serratilabium, D. goldschmidtianum, D. chameleon, D. ceraula, D. yargeri and D. victoriae-reginae. Internally the clade is divided into two subgroups. Historically these species have variously been treated as: belonging to section Dendrobium (Reichenbach 1877), subgenus Pedilonum section Revoluta (Kraenzlin 1910); section Pedilonum (Williams 1937); section Calcarifera (Lavarack 2000, Cootes 2001); or remained unassigned to any particular taxon within Dendrobium (Schlechter 1919, Ames \& Quisumbing 1931, Liu \& Su 1978); or were treated as part of the genus Pedilonum (Rauschert 1984). In describing D. ceraula Reichenbach (1877) considered it belonged to Dendrobium presumably on account of possession of the clustered, lateral inflorescences. Species representative of Dendrobium are by necessity related to $D$. moniliforme the designated type of the genus. As shown in these ITS sequence analyses, D. moniliforme sits well away from the sixth major group so its presumed alliance with species in this grouping is entirely artificial. As stated earlier, Pedilonum is polyphyletic with the type within the third major group, well-isolated from $D$. ceraula and other presumed members of the taxon. Furthermore, the inclusion of D. goldschidtianum renders this group paraphyletic. Cootes (2001) treated D. serratilabium, D. chameleon, D. ceraula, D. yargeri and D. victoriae-reginae in section Calcarifera, on account of the plants branching along the pseudobulb and their pendulous habit. Typical members of section Calcarifera are only present in one clade within the third major group identified in these ITS analyses. Treatment of this group of species in section Calcarifera again renders that taxon polyphyletic. Apart from similarities in plant habit, species in the group have an elongate, narrow labellum spur.

The remaining weakly supported group contains a mixture of strongly as well as weakly supported subgroups and isolated species, with some similarities in floral and vegetative morphology. Part of this group is a poorly supported clade $(<50 \%$ bootstrap support) containing an isolated D. capituliflorum (with thickened canes, capitulate inflorescence, and rigid, concave cymbidiform labellum with an acute apex), and a strongly supported clade (100\% bootstrap support) containing D. cauliculimentum and $D$. rhododioides (with a pendulous, much-branched habit, and flowers with thin texture). On the basis of these results, species in these two clades are representative of two distinct taxa, well isolated from the type of Pedilonum. Sister to the clade containing the proceeding three species is a chained lineage arm of the group with D. morrisonii and D. smillieae at the base. Dendrobium smillieae, with its distinctive large thickened elongate canes, bottlebrush-like inflorescences, and thick, rigid, concave cymbidiform labellum, was described as a separate genus, Coelandria (FitzGerald 1882) but typically is included within sections of Dendrobium, viz. section Dendrocoryne (Bentham 1873), or section Pedilonum (Schlechter 1912, Dockrill 1969, 1992, Lavarack et al. 2001). Results of these ITS sequence analyses do not support its continued placement within section Pedilonum, rather they support recognition as a separate genus Coelandria, which is the oldest available generic name for any taxon within the sixth major group. Dendrobium morrisonii has also been treated as a typical member of section Pedilonum (Lewis \& Cribb 1989) but again these results do not support this proposal.

Dendrobium mohlianum and D. lawesii are typically treated as members of section Calyptrochilus on account of possession of highly visible colourful flowers with an elongate column foot pressed to the ovary, lateral sepals forming an elongated spur, and labellum adnate to the base of the column foot, and labellum apex in turned with lacerate margins. These species are representative of one of the most characteristic taxonomic groups within the Dendrobiinae, comprising over 70 species. Possession of these features coupled with the very strong molecular support for the clade adds 
weight to the concept of their treatment as a separate taxon. This leaves a strongly supported clade containing D. sophronites and D. agathodaemonis; and three species D. fuligidum, D. nothofagicola and D. bracteosum, that have been treated as members of section Pedilonum. Although clearly part of the broader (but weakly supported), major grouping, the true phylogenetic relationship of these three species awaits the study of additional species. What is clear however, is that this is yet another example of the polyphyly of section Pedilonum.

Aside from providing support for the overall taxonomic conclusions about the study taxa, there is also a suggestion of some biogeographical groupings within the study taxa. For example the clade containing D. fairchildiae, D. papilio, D. serratilabium, D. mayakei, D. chameleon, D. ceruela, D. yargeri and D. victoriae-reginae are all representative of species that are endemic to the Philippines and Taiwan. Likewise the remaining major elements of that same clade are all predominantly species found in the New Guinea region of Malesia. These groupings are suggestive of radiation from these regional centres, a feature not uncommon in other orchid genera, e.g. most genera in the tribe Diurideae (Jones \& Clements 2001).

\section{Conclusion}

The overall results obtained in these ITS sequence analyses coupled with data on the morphology of study species, provides a basis for a clearer understanding of the phylogeny of a major part of the Dendrobiinae. At the broadest level, the present ITS results correlate strongly with those produced from analyses of $r b c \mathrm{~L}$ and $m a t \mathrm{~K}$ chloroplast DNA sequences and chloroplast DNA restriction sites (Yukawa et al. 1993, 1996, 2000). This support confirms that a fundamental division exists within the Dendrobiinae into three separate major lineages, viz (i) Epigeneium, (ii) a predominantly Australasian group, and (iii) a predominantly Asian group. The isolation of Dendrobium section Oxystophyllum in the Eriinae is new, providing yet further strong evidence of the polyphyletic nature of the Dendrobiinae. Considering the constant recurrence of these three strongly supported clades in results in all molecular studies, it now seems appropriate and necessary to formally recognise these three distinct lineages of the Dendrobieae. Additionally these results provide evidence for the following: (i) that Brieger's interpretation of Pedilonum is polyphyletic; (ii) that the subsequent automatic transfer by Rauschert (1983) of most species to Pedilonum, and other genera within the Dendrobiinae, is not supported; (iii) that Blume's original concept of Pedilonum had merit; (iv) that Schlechter's concepts of sections Oxyglossum, Calyptochilus and Cuthbertsonia appear monophyletic, whereas his concept of section Pedilonum does not; (v) that Schelchter's interpretation of a close relationship between these four taxa, excluding the type of Pedilonum, was fundamentally sound; (vi) and that section Calcarifera defined by Smith (1908) and later authors is polyphyletic. Consequently these data provide evidence for the recognition and reinstatement of the long established genera Ceraia and Pedilonum, as well as the recognition of several other monophyletic groups at generic rank. Whilst in some authors' opinions the formal recognition of these monophyletic taxa at generic rank might seem premature, the strong body of molecular and morphological evidence from independent data sets and different sources of plant material provides ample support for the proposed reclassification of many of these taxa. In many cases this simply involves the elevation of infrageneric taxa ,but in other cases it involves the redefinition or description of these taxa. Recognition, at generic rank, of major monophyletic taxa within the Dendrobiinae, also provides a far more realistic framework for understanding phylogenies than exists at present. The alternative, of maintaining all these taxa within a greater Dendrobium, is not practical in terms of the complexities of classification now 
required to account for all variation known to exist within this very large and diverse assemblage of species. Additionally, recognition of a broadly circumscribed Dendrobium would sink several well-established useful genera.

Appropriate formal taxonomic changes follow in Appendix 2. The present results have also identified complex areas requiring further research before their phylogeny and systematics can be fully enunciated.

\section{Acknowledgments}

This research was partly funded by the Australian Orchid Foundation, The Nell and Hermon Slade Trust, Sir Robert and Lady Sainsbury, the Foundation for the Protection of Wild Orchids, Zürich, Foundation for Research, Science and Technology, New Zealand and I am most grateful for their support. I particularly wish to thank Ish Sharma and Anne Mackenzie for DNA isolation and sequencing. I also thank many colleagues who have aided in the collection of or contributed plant material used in this study, but in particular David Banks, Marcel Boulet, the late Ralph Crane, T. Jaffré, John Riley, Lewis Roberts, Ron Tunstall, and Ben Wallace. I especially thank Anne Mackenzie and David Jones for helpful discussion and assistance with analyses and comments on the paper. Finally, I wish to thank Peter Weston and the referee for thier valuable suggestions for improvement of the manuscript, and the Telopea Editorial Committee for their commitment to my paper.

\section{References}

Ames, O. (1908) Orchidaceae: Illustrations and Studies of the Family Orchidaceae, 2.( Houghton, Mifflin \& Co., Riverside Press: Cambridge, Boston \& New York).

Bailey, F.M. (1902) The Queensland Flora, 5. (H.J. Diddams \& Co.: Brisbane).

Balakrishnan, N.P. and S. Chowdhury (1966) Notes on orchids of Bhutan-I Epigeneium Gagnep. and Katherinea Hawkes. Bull. Bot. Surv. India 8(3-4): 312-318.

Bentham, G. (1873) Flora Australiensis. Vol. VI, (L. Reeve \& Co.: Covent Garden).

Bentham, G. and Hooker, J.D.(1883) Genera Plantarum, 3(2) (L. Reeve \& Co.: London).

Blume, C.L. (1825) Bijdragen tot de Flora van nederlandsch Indie. (Lands Drukkerij: Batavia).

Brieger, F.G. (1981) Subtribus Dendrobiinae. In F.G. Brieger, R. Maatsch and K. Senghas (eds), Rudolf Schlechter, Die Orchideen: ihre Bescreibung, Kultur und Züchtung, 3rd edn, Band 1, Teil A, Lieferung 11-12. (Paul Parey: Berlin and Hamburg).

Clements, M. A. (1995) Reproductive Biology in relation to phylogeny of the Orchidaceae especially the tribe Diurideae. Ph D thesis. Australian National University, Canberra.

Clements, M. A. (1999) Embryology. In Pridgeon, A.M., Cribb, P.J., Chase, M.W. and F.N. Rasmussen (eds) 'Genera Orchidacearum' Vol. 1. (Oxford University Press: Oxford)

Clements, M. A. (2002) Orchid embryology providing insights into evolution of orchids. In J.Clark, W.M.Elliot, G.Tingley and J.Biro (eds) 'Proceedings of the $16^{\text {th }}$ World Orchid Conference, April 1999'. (Vancouver Orchid Society: Vancouver, British Columbia, Canada).

Clements, M.A. (1999) Embryology. In Pridgeon, A.M., Cribb, P.J., Chase, M.W. and F.N.Rasmussen (eds) 'Genera Orchidacearum' Vol. 1. (Oxford University Press: Oxford).

Clements, M.A. \& D.L.Jones (1996) New species of Dendrobiinae (Orchidaceae) from Papua New Guinea. Lasianthera 1(1): 8-25.

Clements, M.A.\& D.L.Jones (1997) A preliminary taxonomic review of Grastidium Blume and Eriopexis (Schltr.) Brieger (Orchidaceae). Lasianthera 1(2): 1-96.

Clements, M.A. \& D.L.Jones (1998a) Inobulbum (Schltr.) Schltr. et Kraenzl. and Tetradon (Kraenzl.) M.A. Clem. et D.L.Jones, two endemic genera of Dendrobiinae (Orchidaceae) from New Caledonia. Orchadian 12(7): 306-313.

Clements, M.A. \& D.L.Jones (1998b) Cannaeorchis, a new genus of Dendrobiinae (Orchidaceae) for the taxon previously known as Dendrobium Sw. section Macrocladium Schltr. Lasianthera 1(3): $132-147$. 
Clements, M.A. \& D.L.Jones (2002) Nomenclatural changes in the Dendrobieae (Orchidaceae) 1: The Australasian region. Orchadian 13(11): 485-497.

Clements, M.A., Jones, D.L. \& B.P.J. Molloy (1997) Winika, a new monotypic genus for the New Zealand orchid previously known as Dendrobium cunninghamii Lindl. Orchadian 12(5): 214-219.

Clements, M.A., Jones, D.L., Sharma, I.K., Nightingale, M.E., Garratt, M.J., Fitzgerald, K.J., Mackenzie, A.M. and B.P.J. Molloy (2002) Phylogenetic systematics of the Diurideae (Orchidaceae) based on the ITS and 5.8S coding region of nuclear ribosomal DNA. Lindleyana 17(3): 135-171.

Comber, J.B. (1983) The section Calcarifera of the genus Dendrobium in Java. Orchid Digest 47: 191-196.

Comber, J.B. (1990) Orchids of Java. (Bentham-Moxon Trust, Royal Botanic Gardens: Kew).

Comber, J.B. (2001) Orchids of Sumatra. (Royal Botanic Gardens: Kew).

Cootes, J. (2001) The Orchids of the Philippines. (Times Editions: Singapore).

Cribb, P.J. and Whistler, W.A. (1996) Orchids of Samoa. (Royal Botanic Gardens: Kew).

Cribb, P.J., Holttum, R.E., Stewart, J.L., Seidenfaden, G., Garay, L.A. \& Schelpe, E.A. (1985) A note on automatic transfers. Taxon 34: 122-124.

Dockrill, A.W. (1969) Australian Indigenous Orchids, 1. (The Society for Growing Australian Plants. Halstead Press: Sydney).

Dockrill, A.W. (1992) Australian Indigenous Orchids, 2nd edn, vol. 2. (Surrey Beatty \& Sons: Chipping Norton, NSW).

Dressler, R. L. (1974) Classification of the orchid family. Pp. 259-279 in Proceedings of 7th World Orchid Conference. (Editorial Bedout: Medellin).

Dressler, R. L. (1979) The subfamilies of the Orchidaceae. Selbyana 5: 197-206.

Dressler, R. L. (1981) The Orchids: Natural History and Classification. (Harvard University Press: Cambridge).

Dressler, R.L. (1993) Phylogeny and Classification of the Orchid Family. (Dioscorides Press: Portland, Oregon).

Dressler, R. L. \& C. H. Dodson (1960) Classification and phylogeny in the Orchidaceae. Ann. Missouri Bot. Gard. 47: 25-67.

Farris, J. S. 1969. A successive approximations approach to character weighting. Syst. Zool. 18: 374-385.

Felsenstein, J. 1985. Confidence limits on phylogenies: an approach using the bootstrap. Evolution 39: 783-791.

FitzGerald, R.D. (1882) Australian Orchids, 1(7) (Charles Potter: Sydney).

Garay, L.A. \& G.A. Romero-Gonzalez (1999) Schedulae Orchidum II. Harv. Pap. Bot. 4(2): 475-488.

Hallé, N. (1977) Flore de la Nouvelle-Calédonie et Depéndances 8. Orchidacées. (Muséum National D'Histoire Naturelle: Paris).

Hawkes, A.D. (1956) Katherinea, a new name for the orchid genus Sarcopodium. Lloydia 19: 94-98.

Holttum, R.E., Brieger, F.G. \& P.J. Cribb (1979) A proposal for the re-typification of Dendrobium Sw., nom. cons. Taxon 28(4): 409.

Hooker, J.D. (1890) The Flora of British India. (L. Reeve \& Co.: London).

Jones, D.L. (1988) Native Orchids of Australia. (Reed Books: Frenchs Forest).

Jones, D.L. and M. A. Clements. (2001) Tribe Diurideae. In Pridgeon, A.M., Cribb, P.J., Chase, M.W. and Rasmussen, F.N. (eds) 'Genera Orchidacearum' Vol. 2. (Oxford University Press: Oxford).

Kores, P.J. (1991) Family 32. Orchidaceae. In A.C. Smith, Flora Vitiensis Nova. A New Flora of Fiji (Spermatophytes only), vol. 5. (SB Printers Inc.: Honolulu, Hawaii).

Kraenzlin, F. (1910) Orchidaceae-Monandrae-Dendrobiinae, 1. In A. Engler (ed.), Das Pflanzenreich, IV, 50 II B 21, Heft 45: 1-382.

Lavarack, P.S., Harris, W. and Stocker, G. (2000) Dendrobium and its relatives. (Kangaroo Press: East Roseville).

Lewis, B.A. \& Cribb, P.J. (1989) Orchids of Vanuatu. (Royal Botanic Gardens: Kew).

Lewis, B.A. \& Cribb, P.J. (1991) Orchids of the Solomon Islands and Bougainville. (Royal Botanic Gardens: Kew).

Lindley, J. (1830-1840) The Genera and Species of Orchidaceous Plants, 1: Malaxideae. (Ridgways: Picadilly, London).

Lindley, J. (1850) Sarcopodium amplum (Lindl.) Lindl., Paxton's, Fl. Gard. 1: 155.

Lindley, J. and Paxton, J. (1851) The transparent dendrobe. Paxton's Fl. Gard. 1: 133-136, pl. 27.

Lindley, J. (1859) Contributions to the Orchidology of India. No. II, J. Proc. Linn. Soc. Lond. 3: 1-63. 
Loureiro, J. (1790) Flora cochinchinensis. (Lisboa).

Maddison, W. P. and D. R. Maddison (1992) MacClade: Analysis of Phylogeny and Character Evolution. (Version 3.0) [Computer program] (Sinauer Associates: Sunderland, Massachusetts).

Miquel, F.A.W. (1859) Flora van Nederlandsche Indië, 3. (C.G. van der Post: Amsterdam and Utrecht; F. Fleischer: Leipzig).

Moore, L.B. (1970) Orchidaceae. In Moore, L.B. \& E. Edgar (eds), Flora of New Zealand, Vol. II. (Government Printer: Wellington).

O'Byrne, P. (2001) A to Z of South-East Asian Orchid Species. (Orchid Society of South-East Asia: Singapore).

Pfitzer, E. (1887) Entwurf einer natürlichen Anordnung der Orchideen. (C.Winter's Universitätsbuchhandlung: Heidelberg).

Pfitzer, E. (1889) Orchidaceae. Pp. 52-218 in Engler and K. Prantl, Die Natürlichen Pflanzenfamilien, II. Teil, 6. Abteilung (Leipzig).

Quisumbing, E. (1981) The Complete Writings of Dr. Eduardo A. Quisumbing on Philippine Orchids, H.L. Valmayor (ed.) (Eugenio Lopez Foundation, Inc.: Manila).

Rafinesque, C.S. (1836) Flora Telluriana. Second Part. (Philadelphia).

Rauschert, S. (1983) Beitrag zur Nomenklatur der Orchidaceae. Feddes Repert. 94: 433-471.

Reeve, T.M. and Woods, P.J. (1989) A revision of Dendrobium section Oxyglossum (Orchidaceae) Notes Roy. Bot. Gard. Edin. 46: 161-305.

Reichenbach, H.G. (1861) Dendrobium. Ann. Bot. Syst. 6: 279-309.

Reichenbach, H.G. (1868) Loureiros Die Orchideengattungen. Flora 51: 52-53.

Ridley, H.N. (1896) The Orchideae and Apostasiaceae of the Malay Peninsula. J. Linn. Soc., Bot. 32: 213-416.

Rolfe, R.A. (1910) The genus Sarcopodium. Orch. Rev. 18: 237-241.

Royen, P. van (1979) The Alpine Flora of New Guinea, 2: Taxonomic Part, Cupressaceae to Poaceae. (A.R. Gantner Verlag: Vaduz).

Rumphius, G.E. (1750) Herbarium Amboinense, 6. (Amsterdam).

Rupp, H.M.R. and Hunt, T.E. (1948) [1947] A review of the genus Dendrobium (Orchidaceae) in Australia. Proc. Linn. Soc. New South Wales 72: 233-251.

Schelpe, S. \& Stewart, J.L. (1990) Dendrobiums: An Introduction to the Species in Cultivation. (Orchid Sundries Ltd.: Stour Provost, Dorset).

Schlechter, R. (1905) Microspermae. Pp. 69-234 in K. Schumann and K. Lauterbach, Nachträge zur Flora der Deutschen Schutzgebiete in der Südsee. (Leipzig).

Schlechter, R. (1910) Orchidaceae novae et criticae. Decas XII/XIII. Repert. Spec. Nov. Regni Veg. 8: 500-512.

Schlechter, R. (1911a) Revision der Orchidaceen von Deutsch-Samoa. Repert. Spec. Nov. Regni Veg. 9: $98-112$.

Schlechter, R. (1911b) Orchidaceae novae et criticae. Decas XX. Repert. Spec. Nov. Regni Veg. 9: 281-287.

Schlechter, R. (1911c) Zur Kenntnis der Orchidaceen von Celebes. Repert. Spec. Nov. Regni Veg. 10: 66-96.

Schlechter, R. (1912) Die Orchidaceen von Deutsch-Neu-Guinea. Repert. Spec. Nov. Regni Veg. Beih. 1(6-7): 401-560.

Schlechter, R. (1914) Die Orchidaceen von Mikronesien. In G. Volkens (ed.), Beiträge zur flora von Mikronesien, 1. Bot. Jahrb. Syst. 52: 5-13.

Schlechter, R. (1921) Die Orchidaceen von Mikronesien. In L. Diels, Beiträge zur Flora von Mikronesien und Polynesien. II. Bot. Jahrb. Syst. 56: 434-501.

Schlechter, R. (1923a) Neue Orchidaceen Papuasiens [pt]. In C. Lauterbach, Beiträge zur Flora von Papuasien. IX. Bot. Jahrb. Syst. 58: 97-154.

Schlechter, R. (1923b) Figuren-Atlas zu den Orchidaceen von Deutsch-Neu-Guinea. Repert. Spec. Nov. Regni Veg. Beih. 21(7-8): t. 145-192.

Schlechter, R. (1925) Die Orchidaceen der Insel Celebes. Repert. Spec. Nov. Regni Veg. 21: 113-212.

Schlechter, R. (1926) Das System der Orchidaceen, Notizblatt Bot. Gart. Berlin-Dahlem 9: 563-591.

Seidenfaden, G. (1980) Orchid genera in Thailand IX. Flickingeria Hawkes \& Epigeneium Gapnep. Dansk Bot. Arkiv 34(1): 1-104.

Seidenfaden, G. (1985) Orchid genera in Thailand XII. Dendrobium Sw. Opera Bot. 83: 1-296.

Seidenfaden, G. (1992) The orchids of Indochina. Opera Bot. 114: 1-502.

Seidenfaden, G. (1997) Contributions to the Orchid Flora of Thailand XIII. (Olsen \& Olsen: Fredensborg). 
Seidenfaden, G. and Wood, J.J. (1992) The Orchids of Peninsular Malaysia and Singapore. (Olsen \& Olsen: Fredensborg).

Smith, J.J. (1905a) Die Orchideen von Ambon. (Landsdrukkerij: Batavia).

Smith, J.J. (1905b) Die Orchideen von Java. Flora von Buitenzorg, 6. (E.J. Brill: Leiden).

Smith, J.J. (1908a) Neue Orchideen des Malaiischen Archipels II. Bull. Dép. Agric. Indes Néerl. 15: [13-14].

Smith, J.J. (1908b) Vorläufige Beschreibungen neuer papuanischer Orchideen. Bull. Dép. Agric. Indes Néerl. 19: [13-22].

Smith, J.J. (1909) Die Orchideen von Niederländisch Neu-Guinea. Nova Guinea 8(1): 1-148, t. 1-46.

Smith, J.J. (1910a) Vorläufige Beschreibungen neuer papuanischer Orchideen II. Bull. Dép. Agric. Indes Néerl. 39: 1-22.

Smith, J.J. (1910b) Die Orchideen von Java. Bull. Dép. Agric. Indes Néerl. 43: 1-73.

Smith, J.J. (1910c) Die Orchideen von Java. Figuren-Atlas, Drittes: fig. 167-275. (E.J. Brill: Leiden).

Smith, J.J. ([Mar.] 1911a) Vorläufige Beschreibungen neuer papuanischer Orchideen III. Bull. Dép. Agric. Indes Néerl. 45: 1-12.

Smith, J.J. ([Oct.] 1911b) Vorläufige Beschreibungen neuer papuanischer Orchideen, IV. Bull. Jard. Bot. Buitenzorg (ser. 2) 2: 1-20.

Smith, J.J. ([Nov.?] 1911c) Die Orchideen von Niederländisch Neu-Guinea. Nova Guinea 8(3): 521-611, t. 75-112.

Smith, J.J. (1912) Vorläufige Beschreibungen neuer papuanischer Orchideen VI. Repert. Spec. Nov. Regni Veg. 11: 130-140.

Smith, J.J. (1913) Die Orchideen von Niederländisch-Neu-Guinea. Nova Guinea 12(1): 1-108, t. 1-28.

Smith, J.J. (1916) Die Orchideen von Niederländisch-Neu-Guinea. Nova Guinea 12(4): 273-477, t. $100-181$.

Smith, J.J. (1917) Orchidaceae Novae Malayenses VIII. Bull. Jard. Bot. Buitenzorg (ser. 2) 25: 1-103.

Smith, J.J. (1918) Die Orchideen von Java. Bull. Jard. Bot. Buitenzorg (ser. 2) 26: 1-135.

Smith, J.J. (1919) Index orchidacearum quae anno 1919 in Horto Botanico Bogoriensi coluntur. Bull. Jard. Bot. Buitenzorg (ser. 3) 1: 91-129.

Smith, J.J. (1920) Orchidaceae Novae Malayenses IX. Bull. Jard. Bot. Buitenzorg (ser. 3) 2: 15-127.

Smith, J.J. (1922) Orchidaceae Novae Malayenses X. Bull. Jard. Bot. Buitenzorg (ser. 3) 5: 12-102.

Smith, J.J. (1924) Tafeln javanischer Orchideen II. Bull. Jard. Bot. Buitenzorg (ser. 3) 6: 9-10, t. 1-25.

Smith, J.J. (1925) Die Orchideen der zweiten Frankfurter Sunda-Expedition 1909-1910. Meded. Rijks-Herb. 53: 1-17.

Smith, J.J. (1926) The Orchidaceae of Dr. W. Kaudern's Expedition to Selebes 1917-1920. Svensk Bot. Tidskr. 20: 470-482.

Smith, J.J. (1927a) Notizen aus Reichenbachs Herbar. Bull. Jard. Bot. Buitenzorg (ser. 3) 8: 353-369.

Smith, J.J. (1927b) Die Orchideen von Java. Bull. Jard. Bot. Buitenzorg (ser. 3) 9: 23-66.

Smith, J.J. (1928a) Orchidaceae Buruenses. Bull. Jard. Bot. Buitenzorg (ser. 3) 9: 439-481.

Smith, J.J. (1928b) Additions to the orchid-flora of Selebes. Bull. Jard. Bot. Buitenzorg (ser. 3) 10: 1-24.

Smith, J.J. (1928c) Orchidaceae Seranenses. Bull. Jard. Bot. Buitenzorg (ser. 3) 10: 85-172.

Smith, J.J. (1929) Orchidaceae. Nova Guinea 14(3): 337-516, t. 41-87.

Smith, J.J. (1930) On a collection of Orchidaceae from the northern Moluccas. Bull. Jard. Bot. Buitenzorg (ser. 3) 11: 67-81.

Smith, J.J. (1933a) Enumeration of the Orchidaceae of Sumatra and neighbouring islands. Repert. Spec. Nov. Regni Veg. 32: 129-386.

Smith, J.J. (1933b) Orchidaceae selebenses Kjellbergianae. (Selebes-Expedition 1929.) Bot. Jahrb. Syst. 65: 449-508.

Smith, J.J. (1934a) Neue Orchideen Papuasiens aus den Sammlungen von Dr. E. Mayr und G. Stein. In C. Lauterbach, Beiträge zur Flora von Papuasien. XX. Bot. Jahrb. Syst. 66: 161-215.

Smith, J.J. (1934b) Icones Orchidacearum Malayensium I. Bull. Jard. Bot. Buitenzorg (ser. 3) suppl. 2(3-4): t. 51-100.

Smith, J.J. (1934c [1935]) Orchidaceae. Nova Guinea 18(1): 9-85, t. 3-16.

Summerhayes, V.S. (1957) Notes on Asiatic Orchids: II. Kew Bull. 12: 259-268.

Swofford, D. L. 1998. 'PAUP* 4.0b: Phylogenetic Analysis Using Parsimony (and Other Methods)'. (Sinauer Associates: Cambridge, MA).

van Royen, P. 1979. The Alpine Flora of New Guinea, Vol. 2. (Cramer:Vaduz).

Veitch, J. (1888) A Manual of Orchidaceous Plants, 3: Dendrobium, Bulbophyllum and Cirrhopetalum. J. (Veitch \& Sons: Chelsea). 
Wood, J.J. and Comber, J.B. (1988) A new species of Dendrobium section Pedilonum from Java. Orchid Rev. 96: 51-53.

Wood, J.J., Beaman, R.S. and Beaman, J.H. (1993) The plants of Mount Kinabalu 2. Orchids. (Royal Botanic Gardens: Kew).

Wood, J.J. and Cribb, P.J. (1994) A checklist of the Orchids of Borneo. (Royal Botanic Gardens: Kew).

Yukawa, T., Kurita, S., Nishida, M. and Hasebe, M. (1993) Phylogentic implications of chloroplast DNA restriction site variation in subtribe Dendrobiinae (Orchidaceae) Lindleyana 8: 112-221.

Yukawa, Ohba, H., Kurita, Cameron, K.M. and Chase M.W. (1996) Chloroplast DNA phylogeny of subtribe Dendrobiinae (Orchidaceae): insights from a combined analysis basede on rbcL sequences and restriction site variation. J. Plant Research 109: 169-176.

Yukawa, T. and Uehara, K. (1996) Vegetative diversification and radiation in subtribe Dendrobiinae (Orchidaceae): evidence from chloroplast DNA phylogeny and anatomical characters. Plant Syst. Evol. 201: 1-14.

Yukawa, T., Kita, K. and T. Handa (2000) DNA phylogeny and morphological diversification of Australian Dendrobium (Orchidaceae). Pp. 465-471 in K.L.Wilson and D.A.Morrison (eds), Monocots: Systematics and evolution. (CSIRO Publishing: Melbourne). 
Appendix 1. Collection details of the species used for these analyses.

\begin{tabular}{|c|c|c|c|}
\hline Species & Provenance & Collection No. & $\begin{array}{l}\text { GenBank } \\
\text { Accession No. }\end{array}$ \\
\hline Adelopetalum bracteatum Fitzg. & $\begin{array}{l}\text { cult. ex Qmo*; } \\
\text { Queen Mary Falls NP }\end{array}$ & Crane 2138 & AY239945 \\
\hline Bryobium pubescens Lindl. & cult. ex Christmas Island & Ziesing 307 & AY239946 \\
\hline Bulbophyllum nutans Thouars & cult. ex Mauritius & Clements 8108 & AY239947 \\
\hline Cadetia maideniana (Schltr.) Schltr. & cult. ex Qco*; & Jones 4311 & AY239948 \\
\hline $\begin{array}{l}\text { Cannaeorchis fractiflexa (A.Finet) } \\
\text { M.A.Clem. Et D.L.Jones }\end{array}$ & $\begin{array}{l}\text { cult. ex New Caledonia; } \\
\text { Yaté Road }\end{array}$ & Clements 9348 & AY239949 \\
\hline $\begin{array}{l}\text { Dendrobium agathodaemonis } \\
\text { J.J.Sm. }\end{array}$ & cult. ex Indonesia; Irian Jaya & Rose (S 926) & AY239950 \\
\hline $\begin{array}{l}\text { Dendrobium aloifolium } \\
\text { (Blume) Rchb.f. }\end{array}$ & cult. ex Thailand & Clements 9168 & AY239951 \\
\hline $\begin{array}{l}\text { Dendrobium amethystoglossum } \\
\text { Rchb.f. }\end{array}$ & cult. ex Philippines & Cootes(ORG 1482) & AY239952 \\
\hline Dendrobium anceps Sw. & cult. ex Philippines & Clements 9309 & AY239953 \\
\hline Dendrobium bracteosum Rchb.f. & $\begin{array}{l}\text { cult. ex Papua } \\
\text { New Guinea (PNG) }\end{array}$ & CBG 750451 & AY239954 \\
\hline Dendrobium camptocentrum Schltr. & cult. ex New Caledonia & Clements 5830 & AY239955 \\
\hline Dendrobium capituliflorum Rolfe & cult. ex PNG; Wassabamal & Clements 6319 & AY239956 \\
\hline $\begin{array}{l}\text { Dendrobium cauliculimentum } \\
\text { R.S.Rogers }\end{array}$ & cult. ex PNG & ORG 3598 & AY239957 \\
\hline Dendrobium ceraula Rchb.f. & cult. ex Philippines & ORG 2921 & AY239958 \\
\hline Dendrobium cerinum Rchb.f. & cult. ex Philippines & Cootes (ORG 3585) & AY239959 \\
\hline Dendrobium chameleon Ames & cult. ex Philippines & ORG 3590 & AY239960 \\
\hline Dendrobium confusum Schltr. & cult. ex PNG & Banks (ORG 1391) & AY239961 \\
\hline Dendrobium aff. crocatum Hook.f. & $\begin{array}{l}\text { cult. ex Indonesia; } \\
\text { Sumatra }\end{array}$ & Smedley s.n. & AY239962 \\
\hline Dendrobium crumenatum Sw. & cult. ex Thailand & Clements 4890 & AY239963 \\
\hline Dendrobium cyanocentrum Schltr. & cult. ex PNG & $\begin{array}{l}\text { Spence } \\
\text { (Clements 8709) }\end{array}$ & AY239964 \\
\hline $\begin{array}{l}\text { Dendrobium ellipstophyllum } \\
\text { T.Tang et F.T. Wang }\end{array}$ & cult. ex Thailand & Banks (ORG 3581) & AY239965 \\
\hline $\begin{array}{l}\text { Dendrobium fairchildiae } \\
\text { Ames et Quisumb }\end{array}$ & cult. ex Philippines; Bukidnon & $\begin{array}{l}\text { Cootes } \\
\text { (Clements 1485) }\end{array}$ & AY239966 \\
\hline $\begin{array}{l}\text { Dendrobium formosum } \\
\text { Roxb. ex Lindl. }\end{array}$ & cult. ex Thailand & Phillips 457 & AY239967 \\
\hline Dendrobium fulgidum Schltr. & cult. ex PNG & Banks (ORG 3599) & AY239968 \\
\hline
\end{tabular}

* Abbreviations for Australian Botanical Districts: Nsc = New South Wales, South Coast; Qco = Queensland, Cook; Qmo = Queensland, Moreton.

ORG = Orchid Research Group.

CBG = Canberra Botanic Gardens (now the Australian National Botanic Gardens).

RBGS = Royal Botanic Gardens Sydney 


\section{Species}

Dendrobium goldfinchii F.Muell.

Dendrobium goldschmidtianum

Kraenzl.

Dendrobium govidjoae Schltr.

Dendrobium indivisum (Blume) Miq

Dendrobium inflatum Rolfe

Dendrobium ionopus Rchb.f.

Dendrobium junceum Lindl.

Dendrobium lancifolium A. Rich.

Dendrobium lawesii F.Muell.

Dendrobium leonis (Lindl.) Rchb.f.

Dendrobium macrophyllum A.Rich.

Dendrobium mohlianum Rchb.f.

Dendrobium moniliforme (L.) Sw.

Dendrobium morrisonii Schltr.

Dendrobium moschatum

(Buch.-Ham.) Sw.

Dendrobium mutabile (Blume)

Dednrobium nindii W. Hill

Dendrobium nothofagicola

T.M.Reeve

Dendrobium papilio Loher

Dendrobium philippinense Ames

Dendrobium quadrangulare

Parish \& Rchb.f.

Dendrobium aff. rarum Schltr.

Dendrobium rhododioides P.Royen

Dendrobium sanguinolentum Lindl.

Dendrobium secundum (Blume) Lindl.cult. ex Thailand

Dendrobium serratilabium

Dendrobium sinuatum (Lindl.)

Lindl. ex Rchb.f.

Dendrobium smillieae F.Muell.

Dendrobium sophronites Schltr.

Dendrobium speciosum Sm.

Dendrobium stuartii F.M.Bailey
Espirato Santo

cult. ex PNG

cult. ex Phillipines;

Luzon, Laguna

cult. ex PNG; Wassabamal

cult. ex Taiwan

cult. ex PNG; Garassa

cult. ex Indonesia; Bali

cult. ex Philippines

cult. ex Philippines

cult. ex Indonesia; Sulawesi

cult. ex PNG

cult. ex Thailand

cult. ex Fiji

cult. ex Japan

cult. ex Vanuatu

cult. ex Thailand

cult. ex Indonesia; Java

cult. ex Qco*; Daintree River

cult. ex PNG

cult. ex Philippines

cult. ex Philippines

cult. ex Thailand

cult. ex Thailand;

cult. ex Qco*; Captain Billy Ck

cult. ex PNG;

cult. ex Nsc*; Pidgeon

House Mountain

Qco*; Mt Finnigan
Collection No.

Clements 5860
ORG 3465
Clements 6810
Vaughn
(Clements 5822a)

Clements 5820

Cootes (ORG 3589) AY239974

ORG 3588

AY239975

Clements 9176

AY239976

Spence D54

AY239977

ORG 1983

AY239978

Spence

AY239979

(Clements 8704)

ORG 3603

AY239980

no collector 3544

AY239981

Phillips 1069

AY239982

Clements 5808

AY239983

ORG 3608

AY239984

Jones 4285

AY239985

ORG 3600

AY239986

Cootes

AY239987

(Clements 9202)

ORG 1499

AY239988

ORG 1277 (s\#3500) AY239989

Clements 5613 AY239990

ORG 3601

AY239991

Vaughn s.n.

AY239992

Clements 5377

AY239993

Cootes \& L.O.Williams AY239994

(Clements 9180)

ORG 3615

AY239995

Jones 8795

AY239996

Spence s.n.

AY239997

Clements 5058

AY239998

Roberts s.n.

AY239999 


\section{Species}

Dendrobium subuliferum Schltr.

Dendrobium thysiflorum Rchb.f.

Dendrobium truncatum Lindl.

Dendrobium usteroides Schltr.

Dendrobium victoriae-reginae Loher

Dendrobium violaceum Kraenzl.

Dendrobium yeageri

Ames et Quisumb

Diplocaulobium ischnopetalum (Schltr.) Kraenzl.

Dockrillia calamiformis
(Lodd.) M.A.Clem. et D.L.Jones

Drymoanthus flavidus St.George et Molloy

Epigeneium amplum
(Lindl.) Summerh.

Epigeneium cymbidioides

(Blume) Summerh

Epigeneium nakaharaei

(Schltr.) Summerh

Epigeneium triflorum

(Blume) Summerh.

Eria aff. javanica (Sw.) Blume

Flickingeria comata (Blume)

A. Hawkes

Grastidium baileyi (F.Muell.)

Rasuchert

Liparis habenarina (F.Muell.)

Benth.

Oxysepala ovalifolia Wight

Winika cunninghamii (Lindl.) M.A.Clem., D.L.Jones \& Molloy

\section{Provenance}

cult. ex PNG; Torricelli Mts

cult. ex Thailand

cult. ex Malaya; Tamannegara

cult. ex Philippines;

Bulalacao

cult. ex Philippines

cult. ex PNG

cult. ex Philippines

cult. ex PNG; near Lae

cult. ex Qco*

New Zealand; Pounawea

cult. ex India

cult. ex Indonesia; Java

cult. ex Taiwan

cult. ex Indonesia; Java

cult. ex PNG

cult. ex Qco*; Iron Range

cult. ex Qco*

cult. ex Qco*; Stony Creek

cult. ex Thailand

cult. ex New Zealand; Lincoln
Collection No.

GenBank

Accession No.

Clements 9523

AY240000

Clements 5163

AY240001

Vaughn

(Clements 5806)

ORG 3000

AY240003

Cootes (ORG 1484) AY240004

ORG 3597

AY240005

ORG 3580

AY240006

Clements 7270

AY240007

ORG 3469

AY240008

Molloy 207/00

AY240009

Banks s.n.

AY240010

Banks s.n. (ORG 3609) AY240011

Clements 9167

AY240012

ORG 3591

AY240013

CBG 740854

AY240014

Wrigley 354

AY240015

Jones 4165

AY240016

Roberts

(ORG 2154)

RBGS 810771

AY240018

Molloy 061/98

AY240019

\footnotetext{
* Abbreviations for Australian Botanical Districts: Nsc = New South Wales, South Coast; Qco = Queensland, Cook; Qmo = Queensland, Moreton.

$\mathrm{ORG}=$ Orchid Research Group.

CBG = Canberra Botanic Gardens (now the Australian National Botanic Gardens).

RBGS = Royal Botanic Gardens Sydney
} 


\section{Appendix 2: Taxonomy}

Some essential taxonomic and nomenclatural changes arising as a result of these analyses are provided as the next step towards the re-classification of this scientific, horticultural and commercially important group within the Orchidaceae.

Tribe: Podochileae Pfitz., Entw. Nat. Anord. Orch. 101 (1887) (as 'Podochilinae').

Type: Podochilus Blume

Subtribe: Eriinae Benth., J. Linn. Soc., Bot. 18: 287 (1881).

Type: Eria Lindl.

Oxystophyllum Blume, Bijdr. 335-336 (20 Sep-7 Dec 1825).

Type species: Oxystophyllum rigidum Blume, vide Brieger (1981).

Dendrobium Sw. sect. Oxystophyllum (Blume) Miq., Fl. Ind. Neerl. Bat. 3: 644 (1855).

Dendrobium Sw. subg. Aporum (Blume) Kraenzl. sect. Holophylla Karenzl. in Engl., Pflanzenr. Orch.-Mon.Dendr. 1: 201, 203-204 (1910), pro parte min.

Type species: not designated.

Aporum Blume sect. Oxystophyllum (Blume) Brieger, Schltr. Die Orchideen 3, Aufl. 1: 670, 676 (1981)

Epiphytic, erect, reptant to pendulous herbs. Roots thin, wiry, hirsute, rusty brown, the growing apex purplish, arising from the base or from internodes along the stem. Stem thin, flexible, covered with equitant leaf sheath. Leaves equitant, rigid, falcate to lanceolate, with abscission layer towards base, apex sharply acute. Inflorescence simple or compound, compressed raceme, lateral or terminal, equitant, indeterminate, the solitary flowers arising intermittently from the developing raceme; floral bracts persistent and often forming dense tufts. Flowers with sombre colours and thick, fleshy and rigid, with short, acute dorsal sepal and petals, the larger lateral sepals adnate to column-foot forming a saccate base with the labellum. Labellum ligulate, on a short hinge, thick fleshy, and secreting sticky fluids on upper surface. Column very short and with a long, broad curved column-foot. Pollinia 4 in two separate sets of 2, small, irregularly shaped, pinkish cream, and with prominent caudicles.

Distribution: South-East Asia and Malesia as far east as the Solomon islands.

Oxystophyllum acianthum (Schltr.) M.A.Clem., comb. nov.

Basionym: Dendrobium acianthum Schltr., Repert. Spec. Nov. Regni Veg., Beih. 1: 572-572 (1912).

Oxystophyllum ambotiense (J.J.Sm.) M.A.Clem., comb. nov.

Basionym: Dendrobium ambotiense J.J.Sm., Bull. Jard. Bot. Buitenzorg (ser. 3), 9: 466-467 (1928).

Oxystophyllum araneum (J.J.Sm.) M.A.Clem., comb. nov.

Basionym: Dendrobium araneum J.J.Sm., Repert. Spec. Nov. Regni Veg. 12: 397 (1913).

Oxystophyllum atropurpureum Blume, Rumphia 4: 41. t. 193. f. 4; 198 f. C (1858); Dendrobium atropurpureum (Blume) Miq., Fl. Ind. Bat. 3: 644 (1855).

Oxystophyllum atrorubens (Ridl.) M.A.Clem., comb. nov.

Basionym: Dendrobium atrorubens Ridl., J. Linn. Soc., Bot. 32: 247 (1896).

Oxystophyllum bipulvinatum (J.J.Sm.) M.A.Clem., comb. nov.

Basionym: Dendrobium bipulvinatum J.J.Sm., Repert. Spec. Nov. Regni Veg. 12: 397 (1913).

Oxystophyllum buruense (J.J.Sm.) M.A.Clem., comb. et stat. nov.

Basionym: Dendrobium excavatum (Blume) Miq. var. buruense J.J.Sm., Bull. Jard. Bot. Buitenzorg (ser. 3), 9: 466 (1928).

Oxystophyllum capitellatum M.A.Clem., nom. nov.

Basionym: Dendrobium capitellatum Kraenzl. in Engl., Pflanzenr. Orch.-Mon.-Dendr. 1: 215 (1910), non J.J.Sm. (1906).

Oxystophyllum carnosum Blume, Bijdr. 335 (1825); Dendrobium carnosum (Blume) Rchb.f. in Walp., Ann. Bot. 6: 280 (1861), non Presl. (1827), nec Teijsm. et Binn. (1853).

Oxystophyllum changiiangense (S.J.Cheng et C.Z.Tang) M.A.Clem., comb. nov.

Basionym: Dendrobium changiiangense S.J.Cheng et C.Z.Tang, Acta Phytotax. Sin. 18(1): 98-99, f. (1980). 
Oxystophyllum cultratum (Schltr.) M.A.Clem., comb. nov.

Basionym: Dendrobium cultratum Schltr., Repert. Spec. Nov. Regni Veg. 10: 71-72 (1911).

Oxystophyllum cuneatipetalum (J.J.Sm.) M.A.Clem., comb. nov.

Basionym: Dendrobium cuneatipetalum J.J.Sm., Bull. Jard. Bot. Buitenzorg (ser. 3), 9: 157-159 (1927).

Oxystophyllum deliense (Schltr.) M.A.Clem., comb. nov.

Basionym: Dendrobium deliense Schltr., Repert. Spec. Nov. Regni Veg. 11: 143 (1912).

Oxystophyllum elmeri (Ames) M.A.Clem., comb. nov

Basionym: Dendrobium elmeri Ames in Elmer, Leafl. Philipp. Bot. 5: 1573 (1912).

Oxystophyllum excavatum Blume, Bijdr. 335 (1825); Dendrobium excavatum (Blume) Miq., Fl. Ind. Bat. 3: 644 (1855).

Oxystophyllum floridanum (Guillaumin) M.A.Clem., comb. nov.

Basionym: Dendrobium floridanum Guillaumin, Bull. Mus. Hist. Nat. Paris (ser. 2), 37: 199 (1965).

Oxystophyllum govidjoae (Schltr.) M.A.Clem., comb. nov.

Basionym: Dendrobium govidjoae Schltr., Repert. Spec. Nov. Regni Veg., Beih. 1: 572 (1912).

Oxystophyllum hagerupii (J.J.Sm.) M.A.Clem., comb. nov.

Basionym: Dendrobium hagerupii J.J.Sm., Bull. Jard. Bot. Buitenzorg (ser. 3), 5: $78-79$ (1922).

Oxystophyllum helvolum (J.J.Sm.) M.A.Clem., comb. nov.

Basionym: Dendrobium helvolum J.J.Sm., Bot. Jahrb. Syst. 48: 99 (1912).

Oxystophyllum hypodon (Schltr.) M.A.Clem., comb. nov.

Basionym: Dendrobium hypodon Schltr., Repert. Spec. Nov. Regni Veg. 8: 502 (1910); Aporum hypodon (Schltr.) Rauschert, Feddes Repert. 94(7-8): 440 (1983).

Oxystophyllum kaudernii (J.J.Sm.) M.A.Clem., comb. nov.

Basionym: Dendrobium kaudernii J.J.Sm, Svensk Bot. Tidskr. 20: 475-477 (1927).

Oxystophyllum lepoense (Schltr.) M.A.Clem., comb. nov.

Basionym: Dendrobium lepoense Schltr., Repert. Spec. Nov. Regni Veg. 9: 285-286 (1911).

Oxystophyllum lockhartioides (Schltr.) M.A.Clem., comb. nov.

Basionym: Dendrobium lockhartioides Schltr., Repert. Spec. Nov. Regni Veg. 8: 507 (1910).

Oxystophyllum longipecten (J.J.Sm.) M.A.Clem., comb. nov.

Basionym: Dendrobium longipecten J.J.Sm., Bull. Jard. Bot. Buitenzorg (ser. 3), 10: 61-62 (1928).

Oxystophyllum minutigibbum (J.J.Sm.) M.A.Clem., comb. nov.

Basionym: Dendrobium minutigibbum J.J.Sm., Bull. Jard. Bot. Buitenzorg (ser. 2), 13: 3 (1914).

Oxystophyllum moluccense (J.J.Sm.) M.A.Clem., comb. nov.

Basionym: Dendrobium moluccense J.J.Sm., Bull. Jard. Bot. Buitenzorg (ser. 2), 13: 11 (1914).

Oxystophyllum nitidiflorum (J.J.Sm.) M.A.Clem., comb. nov.

Basionym: Dendrobium nitidiflorum J.J.Sm., Repert. Spec. Nov. Regni Veg. 12: 396 (1913).

Oxystophyllum oblongum (Ames et C.Schweinf.) M.A.Clem., comb. nov.

Basionym: Dendrobium oblongum Ames et C.Schweinf., Orchidaceae 6: 108 (1920).

Oxystophyllum oligadenium (Schltr.) M.A.Clem., comb. nov.

Basionym: Dendrobium oligadenium Schltr., Repert. Spec. Nov. Regni Veg. 8: 502-503 (1910).

Oxystophyllum paniferum (J.J.Sm.) M.A.Clem., comb. nov.

Basionym: Dendrobium paniferum J.J.Sm., Bull. Jard. Bot. Buitenzorg (ser. 2), 14: 34 (1914).

Oxystophyllum rigidum Blume, Bijdr. 336 (1825); Dendrobium rigidum (Blume) Miq., Fl. Ind. Neerl. Bat. 3: 644 (1859), nom illeg., non R.Br. (1810), nec Lindl. (1830); Aporum rigidum (Blume) Brieger, Schltr., Die Orchideen 3, Aufl. 1: 676 (1981).

Oxystophyllum sinuatum (Lindl.) M.A.Clem., comb. nov. Basionym: Aporum sinuatum Lindl., Edwards' Bot. Reg. 27; Misc. 3 (1841).

Oxystophyllum speculigerum (Schltr.) M.A.Clem., comb. nov.

Basionym: Dendrobium speculigerum Schltr., Repert. Spec. Nov. Regni Veg. 8: 507-508 (1910). 
Oxystophyllum subsessile (Schltr.) M.A.Clem., comb. nov.

Basionym: Dendrobium subsessile Schltr., Repert. Spec. Nov. Regni Veg. Beih. 1: 571-572 (1912).

Oxystophyllum torricellianum (Kraenzl.) M.A.Clem., comb. nov.

Basionym: Dendrobium torricellianum Kraenzl. in Engl., Pflanzenr. Orch.-Mon.-Dendr. 1: $215-216$ (1910), nom.; Aporum torricellianum (Kraenzl.) Rauschert, Feddes Repert. 94(7-8): 442 (1983). Dendrobium atrorubens Schltr. in K.Schum. et Lauterb., Nachtr. Fl. Deutsch. Südsee 175 (1905), nom. illeg. non Ridl. (1896); Dendrobium simile Schltr., Repert. Nov. Spec. Regni Veg. 3: 80 (1906), nom. illeg., non Schltr. (1905).

Oxystophyllum tropidoneuron (Schltr.) M.A.Clem., comb. nov.

Basionym: Dendrobium tropidoneuron Schltr., Bot. Jahrb. Syst. 45, Beibl. 104, 32 (1911).

Oxystophyllum tumoriferum ( J.J.Sm.) M.A.Clem., comb. nov.

Basionym: Dendrobium tumoriferum J.J.Sm., Bull. Dep. Agric. Indes Néerl. 39: 11 (1910).

Oxystophyllum validipecten ( J.J.Sm.) M.A.Clem., comb. nov.

Basionym: Dendrobium validipecten J.J.Sm., Bull. Jard. Bot. Buitenzorg (ser. 3), 10: 59-60 (1928).

Tribe: Dendrobieae Endl., Gen. Pl. 190 (1837).

Type: Dendrobium Sw.

\section{Subtribe: Epigeneiinae M.A.Clem., subtribus nov.}

Dendrobiinis affinis, sed Bulbophylli et Coelogyne habitu; pseudobulbis turgidis uninodis, aggregatis vel repenti rhizomati separato; pseudobulbis terminalibus foliis 1-3; inflorescentia terminali, uni- vel multiflora; petalis latera columnae adnatis; mento prominenti, differt.

\section{Type: Epigeneium Gagnep. (here designated)}

Plants epiphytic or lithophytic; stems rhizomatous terminating in a single internode pseudobulb; leaves conduplicate, coriaceous, 1-3, terminal; inflorescence subterminal, determinate, single or mutli-flowered, erect or pedant, arising from a prominent erect, imbricate bract; flowers long-lasting, with spreading segments, non-articulate labellum, a prominent long column-foot, petals obliquely attached for greater part or not, glabrous elongate column, with prominent apical often ornate anther attachment.

Distribution: The subtribe comprises one genus distributed throughout South-East Asia and much of the Malaya archipelago.

Note: A full account of the subtribe is in preparation. For further details of the genera Epigeneium and Katherinea A.D.Hawkes, see Balakrishnan and Chowdhury (1966) and Garay and Romero-Gonzalez (1999).

\section{Subtribe: Grastidiinae M.A.Clem., subtribus nov.}

Dendrobiinis affinis sed caulibus vel praecipue durobaculoidibus vel pseudobulbis elongatis et duris; inflorescentia racemosa laterali vel subterminali, abbreviata vel prolongata, uni- vel multi-flora; labello articulato, raro pedi columnae adnato; protocormis discoidis vel globosis, raro late isobilateralibus, differt.

\section{Type: Grastidium Blume. (here designated)}

Terrestrial, lithophytic or epiphytic herbs. Stems comprising one to many internodes, hard, wiry, slender or forming pseudobulbs, indeterminate or determinate. Leaves distichous, duplicate, ligulate, terete or sagittate, articulate, with or without sheaths at base. Inflorescence, lateral or pseudoterminal, usually upper axillary, racemose, rarely paniculate. Flowers solitary, in pairs or numerous, ephemeral, or lasting a few days to several weeks, resupinate or non-resupinate, conspicuous. Sepals, laterals dissimilar to dorsal. Petals similar. Labellum showy, trilobed, sometimes obscurely so, articulate, or fused at base to columnfoot, with central callus ridges. Column elongate or short, glabrous, entire. Anther fleshy, glabrous. Pollinia hard, waxy, glabrous, four, in two pairs appressed together. Protocorms discoid or globose rarely isobilateral-globose.

Distribution: Genera in the subtribe are distributed mainly in Australasia and Malesia with a small number of representative species reaching the Asian mainland.

Note: The Grastidiinae comprises the following genera and for most the taxonomy and nomenclature has been dealt with preliminarily elsewhere. A full account of all taxa within these genera based primarily on the results of molecular analyses of ITS sequence data is in preparation. 
Abaxianthus M.A.Clem. et D.L.Jones, Orchadian 13(11): 485 (2002). Type species: Desmotrichum convexa Blume.

Australorchis Brieger in Schltr., Die Orchideen 1(11-12): 741 (1981). Type species: Australorchis monophylla (F.Muell.) Brieger (= Dendrobium monophyllum F.Muell).

Bouletia M.A.Clem. et D.L.Jones, Orchadian 13(11): 485 (2002). Type species: Dendrobium finetianum Schltr.

Cadetia Gaud. in Freycinet, Voy. Uranie 422, t. 33 (1826 [Sept. 1829] ). Type species: Cadetia umbellatum Gaud.

Cannaeorchis M.A.Clem. et D.L.Jones, Lasianthera 1(3): 132 (1998).

Type species: Dendrobium fractiflexum Finet.

Cepobaculum M.A.Clem. et D.L. Jones, Orchadian 13(11): 486 (2002). Type species: Dendrobium canaliculatum R.Br.

Ceratobium (Lindl.) M.A.Clem. et D.L.Jones, Orchadian 13(11): 486 (2002). Type species: Dendrobium antennatum Lindl.

Davejonesia M.A.Clem, Orchadian 13(11): 487 (2002). Type species: Dockrillia lichenastra (F.Muell.) Brieger.

Dendrobates M.A.Clem. et D.L. Jones, Orchadian 13(11): 487 (2002). Type species: Dendrobium virotii Guillaumin.

Dichopus Blume, Mus. Bat. 2: 176 (1856). Type species: Dichopus insignis Blume.

Diplocaulobium (Rchb.f.) Kraenzl., Pflanzenreich Orch.-Mon.-Dendr. 45: 331 (1910). Type species: Diplocaulobium nitidissimum (Rchb.f.) Kraenzl. (= Dendrobium nitidissimum Rchb.f.).

Dockrillia Brieger, Schltr., Die Orchideen 3(1): 745 (1981). Type species: Dendrobium linguiforme Sw.

Durabaculum M.A.Clem. et D.L. Jones, Orchadian 13(11): 487 (2002). Type species: Dendrobium undulatum R.Br.

Eleutheroglossum (Schltr.) M.A.Clem. et D.L. Jones, Orchadian 13(11): 489 (2002). Type species: Dendrobium eleutheroglossum Schltr.

Eriopexis (Schltr.) Brieger, Schltr., Die Orchideen 3 (1): 656 (1981).

Type species: Dendrobium eriopexis Schltr. (= Eriopexis schlechteri Brieger).

Euphlebium (Kraenzl.) Brieger, Schltr., Die Orchideen 3(1): 722 (1981).

Type species: Dendrocolla spurium Blume.

Exochanthus M.A.Clem. et D.L. Jones, Orchadian 13(11): 496 (2002). Type species: Dendrobium pleianthum Schltr.

Flickingeria A.Hawkes, Orchid Weekly 2(46): 451 (6 Jan. 1961).

Type species: Desmotrichum angulatum Blume (= Flickingeria angulata (Blume) A.D.Hawkes), a substitute name for Desmotrichum Blume 1825 (nom. rej.), non Kuetzing 1845 (nom. cons.).

Grastidium Blume, Bijdr. 7: 333 (1825).

Type species: Grastidium salaccense Blume.

Herpethophytum (Schltr.) Brieger, Schltr., Die Orchideen 1(11-12): 660 (July 1981). Type species: Herpethophytum schlechteri S. Rauschert, (= Dendrobium herpethophytum Schltr.).

Inobulbum (Schltr.) Schltr. et Kraenzl. in Engl. Pflanzenreich, Orch.-Mon.-Dendr. 1: 316 (1910). Type species: Inobulbum muricatum (Finet) Kraenzl. (= Dendrobium muricatum Finet).

Kinetochilus (Schltr.) Brieger, Schltr., Die Orchideen 1(11-12): 686 (July 1981). Type species: Kinetochilus pectinatus (Finet) Brieger (= Dendrobium pectinatum Finet).

Leioanthum M.A.Clem. et D.L. Jones, Orchadian 13(11): 490 (2002).

Type species: Dendrobium biflace Lindl.

Microphytanthe (Schltr.) Brieger, Schltr., Die Orchideen 3(1): 742 (1981).

Type species: Dendrobium bulbophylloides Schltr. 
Monanthos (Schltr.) Brieger, Schltr., Die Orchideen 3(1): 660 (1981) (as 'Monanthus'). Type species: Monanthos biloba (Lindl.) Brieger (= Dendrobium bilobum Lindl.).

Sarcocadetia (Schltr.) M.A.Clem. et D.L. Jones, Orchadian 13(11): 490 (2002). Type species: Cadetia funiformis (Blume) Schltr.

Sayeria Kraenzl., Ost. Bot. Zeitsch. 44: 257-59 (1894).

Type: Sayeria paradoxa Kraenzl.

Stelbophyllum M.A.Clem. et D.L. Jones, Orchadian 13(11): 490 (2002).

Type species: Dendrobium toressae F.M.Bailey.

Tetrabaculum M.A.Clem. et D.L. Jones, Orchadian 13(11): 490 (2002).

Type species: Dendrobium tetragonum A.Cunn.

Tetrodon (Kraenzl.) M.A.Clem. et D.L.Jones, Orchadian 12(7): 310 (1998).

Type species: Eria oppositifolia Kraenzl. (= Dendrobium oppositifolium (Kreanzl.) N. Hallé.

Thelychiton Endl., Prod. Fl. Norf. 32 (1833).

Type species: Thelychiton macropus Endl.

Trachyrhizum (Schltr.) Breiger, Die Orchideen 3(1): 687 (1981)

Type species: Dendrobium chalmersii F. Muell.

Tropilis Rafin., Fl. Tell. 2: 95 (1837)

Type species: Dendrobium aemulum R.Br. (= Tropilis emulum (R.Br.) Rafin.).

Vappodes M.A.Clem. et D.L. Jones, Orchadian 13(11): 492 (2002).

Type species: Dendrobium bigibbum Lindl.

Winika M.A.Clem., D.L.Jones et Molloy, Orchadian 12(5): 214 (1997).

Type species: Dendrobium cunninghamii Lindl.

Subtribe: Dendrobiinae Lindl., Gen. Sp. Orch. Pl. 45 (1830) (as Section II. Dendrobieae). Type: Dendrobium Sw., fide Butzin (1971: 323).

\section{First major group}

Distichorchis M.A.Clem. et D.L.Jones, Orchadian 13(11): 487 (2002).

Basionym: Dendrobium Sw. sect. Distichophyllum Hook.f., Fl. Brit. India 5: 711 (1890).

Type species: Dendrobium uniflorum Griffith, fide Brieger (1981).

Dendrobium Sw. subgen. Grastidium (Blume) Kraenzl. sect. Revoluta (pars 2) Kraenzl. in Engl., Pflanzenr. Orch.-Mon.-Dendr. 1: 181 (1910), pro parte max.

Type species: Dendrobium revolutum Lindl.

Epiphytic or lithophytic herb. Stems psuedobulbous or non-pseudobulbous to c. $80 \mathrm{~cm}$ long. Inflorescence a highly reduced, lateral, periodically developing raceme, protected in a terminal sheathing bract. Flowers solitary, one, occasionally two per inflorescence, each with a papery sheath that persists in the sheathing bracts after anthesis. Labellum fleshy, minutely papillate, towards base on lamina callus, forming a closed, conspicuous, nectiferous spur at the base through fusion of basal half to the column-foot. Column short, concave, papillose on inner surface. Column-foot longer than column. Pollinia four, obliquely-obovate, elongate, glabrous, bright yellow. Capsules near globular, glabrous or hirsute, splitting open longitudinally when mature. Discoid protocorm-seedling type.

Distribution: South-East Asia, Malesia and South-west Pacific Islands.

Notes: The following species are transferred to this genus following detailed research of types and the literature.

Distichorchis angusta (Quisumb.) M.A.Clem., comb. et stat. nov.

Basionym: Dendrobium uniflorum Griff. var. angustum Quisumb., Philipp. Orch. Rev. 3(3): 9, t. 1 (1950).

Distichorchis angustipetala (J.J.Sm.) M.A.Clem., comb. nov.

Basionym: Dendrobium angustipetalum J.J.Sm., Orch. Ambon 59 (1905).

Distichorchis barisana (J.J.Sm.) M.A.Clem., comb. nov.

Basionym: Dendrobium barisanum J.J.Sm., Bull. Jard. Bot. Buitenzorg (ser. 2), 25: 45-46 (1917). 
Distichorchis bifaria (Lindl.) M.A.Clem., comb. nov.

Basionym: Dendrobium bifarium Lindl., Wall., Cat. N. 2002 (1828); Gen. Sp. Orch. Pl. 81 (1830).

Distichorchis bihamulata (J.J.Sm.) M.A.Clem., comb. nov. Basionym: Dendrobium bihamulatum J.J.Sm., Bull. Jard. Bot. Buitenzorg (ser. 2), 25: 43-45 (1917).

Distichorchis cerina M.A.Clem. et D.L.Jones, Orchadian 13(11): 487 (2002).

Basionym: Dendrobium cerinum Schltr., Bot. Jahrb. Syst. 39: 72 (1906), non Rchb.f. (1879); Dendrobium austrocaledonicum Schltr., Repert. Spec. Nov. Regni Veg. 3: 80 (1906), nom.

Distichorchis connata (Blume) M.A.Clem., comb. nov. Baisonym: Onychium connatum Blume, Bijdr. 328 (1825).

Distichorchis dissitifolia (Ridl.) M.A.Clem., comb. nov.

Basionym: Dendrobium dissitifolium Ridl., Trans. Linn. Soc., Bot. 9: 168 (1916).

Distichorchis distachya (Lindl.) M.A.Clem., comb. nov.

Basionym: Dendrobium distachyon Lindl., J. Linn. Soc., Bot. 3: 13 (1859).

Distichorchis elephantina (Finet) M.A.Clem., comb. nov.

Basionym: Dendrobium elephantinum Finet, Bull. Soc. Bot., France 50: 373, t. 11, f. $20-31$ (1903).

Distichorchis ellipsophylla (T.Tang et F.T. Wang) M.A.Clem., comb. nov.

Basionym: Dendrobium ellipsophyllum T.Tang et F.T. Wang, Acta Phytotax. Sin. 1, 1: 81 (1951).

Distichorchis hepatica (J.J.Sm.) M.A.Clem., comb. nov.

Basionym: Dendrobium hepaticum J.J.Sm., Bull. Jard. Bot. Buitenzorg (ser. 2), 25: 48 (1917).

Distichorchis igneonivea (J.J.Sm.) M.A.Clem., comb. nov.

Basionym: Dendrobium igneoniveum J.J.Sm., Bull. Jard. Bot. Buitenzorg (ser. 3), 9: 161 (1927).

Distichorchis kenepaiensis (J.J.Sm.) M.A.Clem., comb. nov.

Basionym: Dendrobium kenepaiense J.J.Sm., Bull. Jard. Bot. Buitenzorg (ser. 2), 25: 46-47 (1918)

Distichorchis lambii (J.J.Wood) M.A.Clem., comb. nov.

Basionym: Dendrobium lambii J.J.Wood, Kew Bull. 38(1): 79, f. 1 (1983).

Distichorchis lamriana (C.L.Chan) M.A.Clem., comb. nov.

Basionym: Dendrobium lamrianum C.L.Chan, Sandakania 5: 67-77, f. 1-2 (1994)

Distichorchis maraiparensis (J.J.Wood et C.L.Chan ) M.A.Clem., comb. nov.

Basionym: Dendrobium maraiparense J.J.Wood et C.L.Chan in C.L.Chan, A.Lamb, P.S.Shim and J.J.Wood, Orch. Borneo 1: 119, f. 25, t. 5E (1994)

Distichorchis melanotricha (Schltr.) M.A.Clem., comb. nov.

Basionym: Dendrobium melanotrichum Schltr., Repert. Spec. Nov. Regni Veg., Beih. 1: 558-559 (1912).

Distichorchis mellicolor (J.J.Sm.) M.A.Clem., comb. nov.

Basionym: Dendrobium mellicolor.J.J.Sm., Bull. Jard. Bot. Buitenzorg (ser. 3), 9: 160 (1927).

Distichorchis metachilina (Rchb.f.) M.A.Clem., comb. nov.

Basionym: Dendrobium metachilinum Rchb.f., Bonplandia 3: 222 (1855).

Distichorchis moquetteana (J.J.Sm.) M.A.Clem., comb. nov.

Basionym: Dendrobium moquetteanum J.J.Sm., Bull. Jard. Bot. Buitenzorg (ser. 2) 25: 50-51 (1917).

Distichorchis multicostata (J.J.Sm.) M.A.Clem., comb. nov.

Basionym: Dendrobium multicostatum J.J.Sm., Bull. Dép. Agric. Indes Néerl. 5: 11 (1907).

Distichorchis nabawanensis (J.J.Wood et A.Lamb) M.A.Clem., comb. nov.

Basionym: Dendrobium nabawanense J.J.Wood et A.Lamb in J.J.Wood et P.J.Cribb, Checklist Orch. Borneo 258, f 32 (1994)

Distichorchis olivacea (J.J.Sm.) M.A.Clem., comb. nov.

Basionym: Dendrobium olivaceum J.J.Sm., Bull. Jard. Bot. Buitenzorg (ser. 2), 8: 41 (1912).

Distichorchis osmophytopsis (Kraenzl.) M.A.Clem., comb. nov.

Basionym: Dendrobium osmophytopsis Kraenzl. in Engl., Pflanzenr. Orch.-Mon.-Dendr. 1: 172 (1910).

Distichorchis ovatifolia (Ridl.) M.A.Clem., comb. nov.

Basionym: Dendrobium ovatifolium Ridl., J. Linn. Soc., Bot. 31: 271 (1896). 
Distichorchis pachyantha (Schltr.) M.A.Clem., comb. nov.

Basionym: Dendrobium pachyanthum Schltr., Repert Spec. Nov. Regni Veg. 9: 290 (1911).

Distichorchis pahangensis (Carr) M.A.Clem., comb. nov.

Basionym: Dendrobium pahangense Carr, Gard. Bull. Straits Settlements 5: 126 (1930).

Distichorchis pandaneti (Ridl.) M.A.Clem., comb. nov.

Basionym: Dendrobium pandaneti Ridl., J. Linn. Soc., Bot. 32: 257 (1896).

Distichorchis piranha (C.L.Chan et P.J.Cribb) M.A.Clem. et D.L.Jones, comb. nov.

Basionym: Dendrobium piranha C.L.Chan et P.J.Cribb in C.L.Chan, A.Lamb, P.S.Shim et J.J.Wood, Orch. Borneo 1: 127, f. 28, t. 6B (1994).

Distichorchis pluricostata (Schltr.) M.A.Clem., comb. nov.

Basionym: Dendrobium pluricostatum Schltr., Repert. Spec. Nov. Regni Veg., Beih. 1: 557-558 (1912).

Distichorchis quadrisulcata (J.J.Sm.) M.A.Clem., comb. nov.

Basionym: Dendrobium quadrisulcatum J.J.Sm., Bull. Jard. Bot. Buitenzorg (ser. 2), 25: 49-50 (1917).

Distichorchis refracta (Teijsm. et Binn.) M.A.Clem., comb. nov.

Basionym: Dendrobium refractum Teijsm. et Binn., Tijdschr. Nederl. Ind. 24: 315-316 (1862).

Distichorchis revoluta (Lindl.) M.A.Clem., comb. nov.

Basionym: Dendrobium revolutum Lindl., Edwards' Bot. Reg. 27; Misc. 51 (1840).

Distichorchis rupicola (Ridl.) M.A.Clem., comb. nov.

Basionym: Dendrobium rupicolum Ridl., J. Fed. Mal. States Mus. 1: 174 (1915).

Distichorchis sandsii (J.J.Wood et C.L.Chan) M.A.Clem., comb. nov.

Basionym: Dendrobium sandsii J.J.Wood et C.L.Chan in C.L.Chan, A.Lamb, P.S.Shim et J.J.Wood, Orch. Borneo 1: 129, f. 29, t. 6C (1994).

Distichorchis siberutensis (J.J.Sm.) M.A.Clem., comb. nov.

Basionym: Dendrobium siberutense J.J.Sm., Bull. Jard. Bot. Buitenzorg (ser. 3), 5: 82-83 (1922).

Distichorchis spathipetala (J.J.Sm.) M.A.Clem., comb. nov.

Basionym: Dendrobium spathipetalum J.J.Sm., Bull. Jard. Bot. Buitenzorg (ser. 2) 13: 20 (1914).

Distichorchis striatiflora (J.J.Sm.) M.A.Clem., comb. nov.

Basionym: Dendrobium striatiflorum J.J.Sm., Repert. Spec. Nov. Regni Veg. 12: 114 (1913).

Distichorchis torquisepala (Kraenzl.) M.A.Clem., comb. nov.

Basionym: Dendrobium torquisepalum Kraenzl. in Engl., Pflanzenr. Orch.-Mon.-Dendr. 1: 187 (1910).

Distichorchis uniflora (Griff.) M.A.Clem., comb. nov.

Basionym: Dendrobium uniflorum Griff., Notul. 3: 305-306 (1851); Icon. Pl. Asia. t. 303 (1851).

Distichorchis xanthophaea (Schltr.) M.A.Clem., comb. nov.

Basionym: Dendrobium xanthophaeum Schltr., Repert. Spec. Nov. Regni Veg., Beih. 1: 558 (1912).

\section{Second major group}

Dendrobium Sw., Nov. Act. Soc. Sci. Upsal. 6: 82 (1799) (nom. cons.).

Type species: Dendrobium moniliforme Sw. (type cons. vide Holttum et al. 1979).

Ormostema Raf., FI. Tellur. 4: 38 (1836).

Type species: Ormostema purpurea Raf. (Epidendrum moniliforme L. = Dendrobium moniliforme sensu

Lindl. $\equiv D$. linawianum Rchb.f.); O. albiflora Raf. (Epidendrum monile Thunb. = Dendrobium monile

(Thunb.) Kuntze $\equiv$ Dendrobium moniliforme (L.) Sw.)

Peirardia Raf., Fl. Tellur. 4: 41 (1836).

Type species: Peirardia bicolor Raf. (= Dendrobium pierardii Roxb.).

Dendrobium Sw. sect. Dendrobium Lindl., Edwards' Bot. Reg. 30: misc. 62 (1844); Lindl. et Paxton in Paxton's Fl. Gard. 1: 135 (1850-51), (as 'sect. Eudendrobium').

Dendrobium Sw. subgen. Dendrobium (Lindl.) Kraenzl. in Engl., Pflanzenr. Orch.-Mon.-Dend. 1: 26-27 (1910), (as 'subg. Eudendrobium').

Dendrobium Sw. subgen. Dendrobium (Lindl.) Kraenzl. sect. Eugenanthe Schltr., Repert. Spec. Nov. Regni Veg., Beih. 1: 445 (1912). 
Epiphytic or lithophytic herbs. Roots thick and fleshy, white, arising at base of new growths. Stems pseudobulbous, thickest near the middle, often with aerial growths. Leaves duplicate, deciduous; sheaths not overlapping. Inflorescence lateral, determinate racemose, with one to five flowers lasting several to many days. Flowers usually showy, erect with spreading segments. Petals and sepals glabrous, spreading, often similar in size and shape, but petals may also be broader. Labellum fleshy, showy, distinctly different to petals, continuous with the column-foot, non-articulate, forming a cavity at their base, obscurely trilobed, covered in papillae, sometimes granular in appearance. Column short, concave, broad nearest the base, glabrous. Anther cap large and ornate. Pollinia elongate, lunate, four $(2 \times 2)$ appressed together, yellow glabrous. Capsule elongate, fusiform. Elongate protocorm-seedling type.

Distribution: Found throughout South-East Asia, Malesia and Australia (represented by a single species).

Note: Furthur systematics of this group will be published separately (Clements et al. in prep.).

\section{Third major group}

Anisopetala (Kraenzl.) M.A.Clem., gen. et stat. nov.

Basionym: Dendrobium Sw. subgen. Dendrobium sect. Anisopetala Kraenzl. in Engl., Pflanzenr. Orch.Mon.-Dendr. 1: 27, 68 (1910).

Type species: Dendrobium mutabile (Blume) Lindl., vide Brieger (1981: 698).

Pedilonum Blume sect. Sanguinolenta Brieger, Schltr., Die Orchideen 3(1): 681 (1981).

Type species: Pedilonum sanguinolentum (Lindl.) Brieger (= Dendrobium sanguinolentum Lindl.).

Plants epiphytic herbs. Stems elongate, narrow, relatively fleshy. Leaves along almost their entire length when young, deciduous prior to flowering. Inflorescence lateral, the peduncles short and usually pendulous, bearing 1-14 flowers. Flowers showy, with a distinct mentum fusion of the basal part of the lateral sepals, and always held away from the ovary and pedicel; free parts of sepals and petals spreading; labellum with distinct claw, with or without a small projection on the upper surface near the base, the apical part spreading, usually without distinct sidelobes, and with a bilobed apex.

Distribution: South-East Asia, western Malesia and the Philippines.

Notes: The following species are transferred to this genus following detailed research of types and the literature.

Anisopetala acutimenta (J.J.Sm.) M.A.Clem., comb. nov.

Basionym: Dendrobium acutimentum J.J.Sm., Bull. Jard. Bot. Buitenzorg (ser. 2), 25: $53-54$ (1917).

Anisopetala annae (J.J.Sm.) M.A.Clem., comb. nov.

Basionym: Dendrobium annae J.J.Sm, Orch. Java 354-355 (1905).

Anisopetala biflora (Blume) M.A.Clem., comb. nov.

Basionym: Pedilonum biflorum Blume, Bijdr. 1: 322 (1825).

Anisopetala calicopis (Ridl.) M.A.Clem., comb. nov.

Basionym: Dendrobium calicopis Ridl., J. As. Soc. Straits 39: 72 (1903).

Anisopetala filicaulis (Gapnep.) M.A.Clem., comb. nov.

Basionym: Dendrobium filicaule Gagnep., Bull. Mus. Hist. Nat. Paris (ser. 2), 21: 741 (1949)

Anisopetala fulminicaulis (J.J.Sm.) M.A.Clem., comb. nov.

Basionym: Dendrobium fulminicaule J.J.Sm., Bull. Jard. Bot. Buitenzorg (ser. 2), 25: 51-53 (1917).

Anisopetala hughii (Rchb.f.) M.A.Clem., comb. nov.

Basionym: Dendrobium hughii Rchb.f., Gard. Chron. (new ser.) 17: 764 (1882).

Anisopetala inflata (Rolfe) M.A.Clem., comb. nov. Basionym: Dendrobium inflatum Rolfe, Kew Bull. 61 (1895).

Anisopetala lucens (Rchb.f.) M.A.Clem., comb. nov.

Basionym: Dendrobium lucens Rchb.f., Bot. Zeit. (Berlin) 21: 128 (1863).

Anisopetala montana (J.J.Sm.) M.A.Clem., comb. nov.

Basionym: Dendrobium montanum J.J.Sm., Orchid. Java 363-364 (1905).

Anisopetala mutabilis (Blume) M.A.Clem., comb. nov.

Basionym: Onychium mutabile Blume, Bijdr. 324 (1825). 
Anisopetala nuda (Blume) M.A.Clem., comb. nov. Basionym: Onychium nudum Blume, Bijdr. 324 (1825).

Anisopetala rigida (Blume) M.A.Clem., comb. nov. Basionym: Onychium rigidum Blume, Bijdr. 324 (1825).

Anisopetala sanguinolenta (Lindl.) M.A.Clem., comb. nov.

Basionym: Dendrobium sanguinolentum Lindl., Edwards' Bot. Reg. 28: 62, misc. 73 (1842).

Anisopetala spathilinguis (J.J.Sm.) M.A.Clem., comb. nov.

Basionym: Dendrobium spathilingue J.J.Sm., Bull. Jard. Bot. Buitenzorg (ser. 2), 9: 64 (1913).

Anisopetala transtillifera (J.J.Sm.) M.A.Clem., comb. nov.

Basionym: Dendrobium transtilliferum J.J.Sm., Bull. Jard. Bot. Buitenzorg (ser. 3), 5: 85-86 (1922).

Eurycaulis M.A.Clem. et D.L.Jones, Orchadian 13(11): 490 (2002).

Basionym: Dendrobium Sw. sect. Platycaulon Schltr. in K.Schum. et Laut., Fl. Schutzg. Südsee, Nachtr. 150 (1905) (as 'Platybulbon', orth. error).

Type species: Dendrobium lamellatum (Blume) Lindl. (as 'lamellatus').

Dendrobium Sw. sect. Dendrocoryne Lindl.. Edwards' Bot. Reg. 28: Misc. 76 (1842).

Type species: Dendrobium compressum Lindl.

Pedilonum Blume sect. Platycaulon (Schltr.) Brieger, Schltr., Die Orchideen 3(1): 685 (1981).

Type species: Onychium lamellatum Blume $\equiv$ Dendrobium lamellatum (Blume) Lindl. $\equiv$ Pedilonum lamellatum (Blume) Brieger

Dendrobium Sw. subgen. Dendrocoryne (Lindl.) Kraenzl. sect. Platycaula Kraenzl. in Engl., Pflanzenr. Orch.-Mon.-Dendr. 1: 242, 266-267 (1910).

Type species: Dendrobium platycaulon Rolfe.

Notes: The following species are transferred to this genus following detailed research of types and the literature. The genus comprises two subgenera based on the results of these studies.

\section{Eurycaulis subgen. Eurycaulis}

Plants epiphytic; stems elongate, fusiform, narrowest in basal half, laterally flattened, fleshy; leaves thin conduplicate, alternate, present in upper half, deciduous prior to flowering; inflorescence short lateral, peduncles short and usually pendulous, bearing 1-14 flowers; flowers showy, or if not opening widely these usually being cleistogamous, forming a distinct mentum fusion of the basal part of the lateral sepals and always held away from the ovary and pedicel; free parts of sepals and petals spreading; labellum with distinct claw, with or without a small projection on the upper surface near the base, the apical part spreading, without distinct sidelobes, and with bilobed apex.

Distribution: Malesia as far east as the Solomon Islands.

Eurycaulis camptocentrus (Schltr.) M.A.Clem. et D.L.Jones, Orchadian 13(11): 490 (2002).

Eurycaulis compressus (Lindl.) M.A.Clem., comb. nov.

Basionym: Dendrobium compressum Lindl., Edwards' Bot. Reg. 28, Misc. 76 (1842).

Eurycaulis discocaulon (Schltr.) M.A.Clem., comb. nov.

Basionym: Dendrobium discocaulon Schltr., Repert. Spec. Nov. Regni Veg., Beih. 1: 501 (1912).

Eurycaulis lamellatus (Blume) M.A.Clem. et D.L.Jones, Orchadian 13(11): 490 (2002).

Basionym: Onychium lamellatum Blume, Bijdr. 526 (1825).

Eurycaulis lamprocaulon (Schltr.) M.A.Clem., comb. nov.

Basionym: Dendrobium lamprocaulon Schltr. in K. Schum. et Laut., Nachtr. Fl. Deutsch. Südsee 166 (1905).

Eurycaulis milaniae (H.Fessel et E.Lückel) M.A.Clem., comb. nov.

Basionym: Dendrobium milaniae H.Fessel et E.Lückel, Orchidee 47(3): A131 (1996).

Eurycaulis platycaulon (Rolfe) M.A.Clem., comb. nov.

Basionym: Dendrobium platycaulon Rolfe, Kew Bull. 139 (1892).

Eurycaulis platygastrius (Rchb.f.) M.A.Clem., comb. nov.

Basionym: Dendrobium platygastrium Rchb.f., Otia Bot. Hamb. 55 (1878). 
Eurycaulis praetermissus (Seidenf.) M.A.Clem., comb. nov.

Basionym: Dendrobium praetermissum Seidenf., Contr. Orch. Fl. Thailand XIII: 34, f. 7 (1997).

Eurycaulis remiformus (J.J.Sm.) M.A.Clem., comb. nov.

Basionym: Dendrobium remiforme J.J.Sm., Repert. Spec. Nov. Regni Veg. 12: 111 (1913).

Eurycaulis septemcostulatus (J.J.Sm.) M.A.Clem., comb. nov.

Basionym: Dendrobium septemcostulatum J.J.Sm., Bull. Jard. Bot. Buitenzorg (ser. 3), 2: 8384 (1920).

Eurycaulis treubii (J.J.Sm.) M.A.Clem., comb. nov.

Basionym: Dendrobium treubii J.J. Sm., Orch. Ambon 65 (1905); Kc. Bogor. 3: 29-30, t. 212 (1906).

Eurycaulis ypsilon (Seidenf.) M.A.Clem., comb. nov.

Basionym: Dendrobium ypsilon Seidenf., Opera Bot. 83: 158 (1985).

Eurycaulis subgen. Calcariferus (J.J.Sm.) M.A.Clem., subgen. et stat. nov.

Basionym: Dendrobium Sw. sect. Calcarifera J.J.Sm., Bull. Dép. Agric. Indes Néerl. 15: 14 (1908).

Type species: Dendrobium pedicellatum J.J.Sm.

Plants epiphytic; stems elongate, narrow, relatively fleshy; leaves along almost their entire length, deciduous prior to flowering; inflorescences lateral, the peduncles short and usually pendulous, bearing 1-14 flowers; flowers showy, forming a distinct mentum fusion of the basal part of the lateral sepals and always held away from the ovary and pedicel; free parts of sepals and petals spreading; labellum with distinct claw, with or without a small projection on the upper surface near the base, the apical part spreading, without distinct sidelobes, and with bilobed apex.

Distribution: South-East Asia and Malay archipelago.

Eurycaulis acutifolius (Ridl.) M.A.Clem., comb. nov.

Basionym: Dendrobium acutifolium Ridl., J. Fed. Mal. States Mus. 8: 91-92 (1917).

Eurycaulis annamensis (Rolfe) M.A.Clem., comb. nov.

Basionym: Dendrobium annamense Rolfe., Kew Bull. 113-114 (1906).

Eurycaulis anthrene (Ridl.) M.A.Clem., comb. nov.

Basionym: Dendrobium anthrene Ridl., J. Linn. Soc., Bot. 31: 272 (1896).

Eurycaulis appendiculoides M.A.Clem., nom. nov.

Basionym: Dendrobium appendiculoides Ames, Orchidaceae 7: 93-94 (1922), nom. illeg., non J.J.Sm. (1913).

Eurycaulis arcuatus (J.J.Sm.) M.A.Clem., comb. nov.

Basionym: Dendrobium arcuatum J.J.Sm., Orch. Java 357 (1905).

Eurycaulis atjehensis (J.J.Sm.) M.A.Clem., comb. nov.

Basionym: Dendrobium atjehense J.J.Sm., Bull. Jard. Bot. Buitenzorg (ser. 3), 12: 137 (1932).

Eurycaulis bicallosus (Ridl.) M.A.Clem., comb. nov.

Basionym: Dendrobium bicallosum Ridl., J. Fed. Mal. States Mus. 8(4): 92-93 (1917).

Eurycaulis boumaniae (J.J.Sm.) M.A.Clem., comb. nov.

Basionym: Dendrobium boumaniae J.J.Sm., Bull. Jard. Bot. Buitenzorg (ser. 3), 8: 55-56 (1926).

Eurycaulis calcariferus (Carr) M.A.Clem., nom. nov.

Basionym: Dendrobium calcariferum Carr, Gard. Bull. Straits Settlement 8: 107-108 (1935).

Eurycaulis cerinus (Rchb.f.) M.A.Clem., comb. nov.

Basionym: Dendrobium cerinum Rchb.f., Gard. Chron. (ser. 2), 12: 554 (1879).

Eurycaulis cinereus (J.J.Sm.) M.A.Clem., comb. nov.

Basionym: Dendrobium cinereum J.J.Sm., Bull. Jard. Bot. Buitenzorg (ser. 3), 2: 78-79 (1920).

Eurycaulis compressimentus (J.J.Sm.) M.A.Clem., comb. nov.

Basionym: Dendrobium compressimentum J.J.Sm., Bull. Jard. Bot. Buitenzorg (ser. 3), 10: 63-64 (1928).

Eurycaulis corallorhizus (J.J.Sm.) M.A.Clem., comb. nov.

Basionym: Dendrobium corallorhizon J.J.Sm., Bull. Jard. Bot. Buitenzorg (ser. 3), 10: 140-141 (1931).

Eurycaulis courtauldii (Summerh. ex J.J.Wood) M.A.Clem., comb. nov.

Basionym: Dendrobium courtauldii Summerh. ex J.J.Wood, Orchid Rev. 89(1056): 322 (1981). 
Eurycaulis crabro (Ridl.) M.A.Clem., comb. nov.

Basionym: Dendrobium crabro Ridl., J. As. Soc. Straits 50: 133 (1908).

Eurycaulis crassimarginatus (L.O.Williams) M.A.Clem., comb. nov.

Basionym: Dendrobium crassimarginatum L.O.Williams, Bot. Mus. Leafl. Harvard Univ. 5: 42-44 (1937).

Eurycaulis crocatus (Hook.f.) M.A.Clem., comb. nov.

Basionym: Dendrobium crocatum Hook.f., Fl. Brit. Ind. 6: 185 (1890).

Eurycaulis croceocentrus (J.J.Sm.) M.A.Clem., comb. nov.

Basionym: Dendrobium croceocentrum J.J.Sm., Bull. Jard. Bot. Buitenzorg (ser. 3), 2: 75-76 (1920).

Eurycaulis cumulatus (Lindl.) M.A.Clem., comb. nov.

Basionym: Dendrobium cumulatum Lindl., Gard. Chron. 756 (1855).

Eurycaulis curvus (Ridl.) M.A.Clem., comb. nov.

Basionym: Dendrobium curvum Ridl., J. Fed. Mal. States Mus. 8: 91 (1917).

Eurycaulis cymbiformis (Rolfe) M.A.Clem., comb. nov.

Basionym: Dendrobium cymbiforme Rolfe, Kew Bull. 192 (1898)

Eurycaulis cymboglossus (J.J.Wood et A.Lamb) M.A.Clem., comb. nov.

Basionym: Dendrobium cymboglossum J.J.Wood et A.Lamb in J.J.Wood et P.J.Cribb, Checklist Orch.Borneo 247-248, f. 29, t. 8 C (1994).

Eurycaulis derryi (Ridl.) M.A.Clem., comb. nov.

Basionym: Dendrobium derryi Ridl., Mat. Fl. Mal. Penins. 1: 52 (1907).

Eurycaulis diffusus (L.O.Williams) M.A.Clem., comb. nov.

Basionym: Dendrobium diffusum L.0.Williams, Bot. Mus. Leaf. Harvard Univ. 5: 44-45 (1937).

Eurycaulis endertii (J.J.Sm.) M.A.Clem., comb. nov.

Basionym: Dendrobium endertii J.J.Sm., Bull. Jard. Bot. Buitenzorg (ser. 3),11: 138 (1931).

Eurycaulis exilicaulis (Ridl.) M.A.Clem., comb. nov.

Basionym: Dendrobium exilicaule Ridl., Fl. Mal. Penins. 4: 50 (1924).

Eurycaulis fimbrilabius (J.J.Sm.) M.A.Clem., comb. nov.

Basionym: Dendrobium fimbrilabium J.J.Sm., Bull. Jard. Bot. Buitenzorg (ser. 3), 2: 81-82 (1920).

Eurycaulis foetens (Kraenzl.) M.A.Clem., comb. nov.

Basionym: Dendrobium foetens Kraenzl. in Engl., Pflanzenr. Orch.-Mon.-Dendr. 1: 77-78 (1910)

Eurycaulis foxii (Ridl.) M.A.Clem., comb. nov.

Basionym: Dendrobium foxii Ridl., J. Bot. 38: 70 (1900)

Eurycaulis grastidioides (J.J.Sm.) M.A.Clem., comb. nov.

Basionym: Dendrobium grastidioides J.J.Sm., Bull. Jard. Bot. Buitenzorg (ser. 3), 2: 80-81 (1920).

Eurycaulis groeneveldtii (J.J.Sm.) M.A.Clem., comb. nov.

Basionym: Dendrobium groeneveldtii J.J.Sm., Bull. Jard. Bot. Buitenzorg (ser. 3), 2: 79-80 (1920).

Eurycaulis guerreroi (Ames et Quisumb.) M.A.Clem., comb. nov.

Basionym: Dendrobium guerreroi Ames et Quisumb., Philipp. J.. Sci. 49: 489 (1932).

Eurycaulis hamatus (Rolfe) M.A.Clem., comb. nov.

Basionym: Dendrobium hamatum Rolfe, Kew Bull. 183 (1894).

Eurycaulis hamaticalcar (J.J.Wood et Dauncey) M.A.Clem., comb. nov.

Basionym: Dendrobium hamaticalcar J.J.Wood et Dauncey in J.J.Wood, Baeman et Beaman, Pl. Mt Kinabalu 2, Orch. 168, f. 20 (1993).

Eurycaulis huttonii (Rchb.f.) M.A.Clem., comb. nov.

Basionym: Dendrobium huttonii Rchb.f., Gard. Chron. 686 (1869).

Eurycaulis hymenanthus M.A.Clem., nom. nov.

Basionym: Dendrobium hymenanthum Hook.f., Fl. Brit. Ind. 5: 732 (1890); Icon. Pl. t. 2032 (1890); 6: 185 (1890), nom. illeg., non Rchb.f. (1855).

Eurycaulis intricatus (Gagnep.) M.A.Clem., comb. nov.

Basionym: Dendrobium intricatum Gagnep., Bull. Mus. Hist. Nat. Paris (ser. 2), 2: 236 (1930). 
Eurycaulis ionopus (Rchb.f.) M.A.Clem., comb. nov.

Basionym: Dendrobium ionopus Rchb.f., Gard. Chron. 2: 808 (1882).

Eurycaulis kentrochilus (Hook.f.) M.A.Clem., comb. nov.

Basionym: Dendrobium kentrochilum Hook.f., Fl. Brit. Ind. 5: 731(1890); Icon. Pl. t. 2030 (1890).

Eurycaulis kruiensis (J.J.Sm.) M.A.Clem., comb. nov.

Basionym: Dendrobium kruiense J.J.Sm., Bull. Jard. Bot. Buitenzorg (ser. 3), 8: 56-57 (1926).

Eurycaulis lampongensis (J.J.Sm.) M.A.Clem., comb. nov.

Basionym: Dendrobium lampongense J.J.Sm., Bull. Dépt. Agric. Néerl. 15: 14-15 (1908).

Eurycaulis lankaviensis (Ridl.) M.A.Clem., comb. nov.

Basionym: Dendrobium lankaviense Ridl., J. As. Soc. Straits 54: 49 (1910).

Eurycaulis leucochlorus (Rchb.f.) M.A.Clem., comb. nov.

Basionym: Dendrobium leucochlorum Rchb.f., Gard. Chron. 1: 202 (1879).

Eurycaulis lilacinus M.A.Clem., nom. nov

Basionym: Dendrobium lilacinum Rchb.f., Gard. Chron. 674 (1865), non Teijsm. et Binn.(1864).

Eurycaulis Iucens (Rchb.f.) M.A.Clem., comb. nov.

Basionym: Dendrobium lucens Rchb.f., Bot. Zeit. (Berlin) 21: 128 (1863).

Eurycaulis maierae (J.J.Sm.) M.A.Clem., comb. nov.

Basionym: Dendrobium maierae J.J.Sm., Bull. Jard. Bot. Buitenzorg (ser. 3), 2: 76-78 (1920).

Eurycaulis megaceras (Hook.f.) M.A.Clem., comb. nov.

Basionym: Dendrobium megaceras Hook.f., Fl. Brit. Ind. 5: 713 (1888); Icon. PI. t. 2031 (1890).

Eurycaulis modestus M.A.Clem., nom. nov.

Basionym: Dendrobium modestum Ridl., J. Bot. 211(1898), non Rchb.f.(1855)

Eurycaulis multiflorus M.A.Clem., nom. nov.

Basionym: Dendrobium multiflorum Ridl., Journ. As. Soc. Straits I: 134 (1908), non Par. et Rchb.f. (1874).

Eurycaulis nieuwenhuisii (J.J.Sm.) M.A.Clem., comb. nov.

Basionym: Dendrobium nieuwenhuisii J.J.Sm., Ic. Bogor. 3: 25-27: t. 211 (1906).

Eurycaulis obrienianus (Kraenzl.) M.A.Clem., comb. nov.

Basionym: Dendrobium o'brienianum Kraenzl., Gard. Chron. (ser. 3), 11: 266 (1892).

Eurycaulis paathii (J.J.Sm.) M.A.Clem., comb. nov.

Basionym: Dendrobium paathii J.J.Sm., De Orchidee (Bandoeng) 4: 183 (1935); Orch. Rev. 43: 290, in obs (1935); Gard. Bull. Straits Settlements 9: 90 (1935).

Eurycaulis panduriferus (Hook.f.) M.A.Clem., comb. nov.

Basionym: Dendrobium panduriferum Hook.f., Fl. Brit. India 6: 186 (1890)

Eurycaulis pedicellatus (J.J.Sm.) M.A.Clem., comb. nov.

Basionym: Dendrobium pedicellatum J.J.Sm., Bull. Dép. Agric. Indes Néerl. 15: 13 (1908).

Eurycaulis peralu (Rchb.f.) M.A.Clem., comb. nov.

Basionym: Dendrobium peralu Rchb.f., Hamb. Gartenz. 21: 298 (1865).

Eurycaulis pictus (Lindl.) M.A.Clem., comb. nov.

Basionym: Dendrobium pictum Lindl., Gard. Chron. 548 (1862).

Eurycaulis profusus (Rchb.f.) M.A.Clem., comb. nov.

Basionym: Dendrobium profusum Rchb.f., Gard. Chron. 1: 510 (1884).

Eurycaulis rantii (J.J.Sm.) M.A.Clem., comb. nov.

Basionym: Dendrobium rantii J.J.Sm., Repert. Spec. Nov. Regni Veg. 36: 114-115 (1934).

Eurycaulis rappardii (J.J.Sm.) M.A.Clem., comb. nov.

Basionym: Dendrobium rappardii J.J.Sm., Blumea 5: 308 (1943).

Eurycaulis rhodocentrum (Rchb.f.) M.A.Clem., comb. nov.

Basionym: Dendrobium rhodocentrum Rchb.f., Gard. Chron. 426 (1872).

Eurycaulis roseatus (Ridl.) M.A.Clem., comb. nov.

Basionym: Dendrobium roseatum Ridl., J. Linn. Soc. 32: 261 (1896). 
Eurycaulis singalanensis (Kraenzl.) M.A.Clem., comb. nov.

Basionym: Dendrobium singalanense Kraenzl. in Engl., Pflanzenr. Orch.-Mon.-Dendr. 1: 167 (1910).

Eurycaulis subflavidus (Ridl.) M.A.Clem., comb. nov.

Basionym: Dendrobium subflavidum Ridl., J. Linn. Soc., Bot. 38: 324 (1908).

Eurycaulis tropaeoliflorus (Hook.f.) M.A.Clem., comb. nov.

Basionym: Dendrobium tropaeoliflorum Hook.f., Fl. Brit. Ind. 6: 186 (1890).

Eurycaulis undulatus (Lindl.) M.A.Clem., comb. nov.

Basionym: Pedilonum undulatum Blume, Bijdr. 322, t. 36 (1825).

Eurycaulis ventrilabius (J.J.Sm.) M.A.Clem., comb. nov.

Basionym: Dendrobium ventrilabium J.J.Sm., Bull. Jard. Bot. Buitenzorg (ser. 3), 5: 84-85 (1922).

Eurycaulis viriditepalus (J.J.Sm.) M.A.Clem., comb. nov.

Basionym: Dendrobium viriditepalum J.J.Sm., Bull. Jard. Bot. Buitenzorg (ser. 2), 25: 54-56 (1917).

Eurycaulis viridulus (Ridl.) M.A.Clem., comb. nov.

Basionym: Dendrobium viridulum Ridl., J. Linn. Soc. 32: 259 (1896).

Eurycaulis zamboangensis (Ames) M.A.Clem., comb. nov.

Basionym: Dendrobium zamboangense Ames, Orchidaceae 5: 145 (1915

Pedilonum (Blume) Blume, Bijdr. Fl. Ned. Ind.: 320 (1825)

Dendrobium Sw. sect. Pedilonum Blume, Bijdr. Fl. Ned. Ind.: tab. 4 (1825).

Type species: Dendrobium secundum (Blume) Lindl. ex Wall., vide Rafinesque (1836: 44).

Dendrobium Sw. sect. Dendrobium subsect. Pedilonum (Blume) Pfitzer in Engl. and Prantl, Nat. Pflanzenfam. 2(6): 174 (1888).

Dendrobium Sw. subgen. Pedilonum (Blume) Kraenzl. in Engl., Pflanzenr. Orch.-Mon.-Dendr. 1: 96 (1910)

Erect to pendulous epiphytic herb. Stems stout, clustered, cylindric to more or less cylindric-fusiform. Leaves coriaceous, somewhat twisted at base, linear-oblong to elliptic-ovate. Inflorescence densely multiflowered, arising from upper nodes of leafless stems. Flowers secund, waxy, purple, pink, rarely white, the labellum lamina usually orange or yellow; pedicellate ovary cylindric-clavate. Dorsal sepal slightly concave, ovate-triangular to elliptic-oblong, acute. Lateral sepals obliquely falcate to tringular, elliptic-oblong, acute to acuminate; mentum equalling or slightly longer than free part, fused to labellum, saccate. Petals small, obliquely linear-obovate to narrowly elliptic, acute. Labellum linear-spathulate, lamina narrowly linearelliptic to obovate-cuneate, acute to acuminate, saccate for basal two-thirds, shallowly concave above, fused to column-foot, transverse callus $V$-shaped to semilunate. Column short, laterally dilated toward apex, with sunken stigma, and protruding hard, plate-like rostellum. Column-foot curved, slightly thickened below stigma, with basal nectary. Capsule oblique ellipsoidal-ovoid.

Distribution: South-East Asia and the Malesian Archipelago.

Pedilonum amethystoglossum (Rchb.f.). M.A.Clem., comb. nov.

Basionym: Dendrobium amethystoglossum Rchb.f., Gard. Chron. 109 (1872).

Pedilonum secundum Blume, Bijdr. Fl. Ned. Ind.: 322 (1825).

\section{Fourth major group}

Callista Lour. Fl. Cochinch. 2: 519 (1790).

Type species: Callista amabilis Lour.

Endeisa Rafin., Fl. Tellur. 2: 52 (1836)[1837].

Type species: Endeisa flava Raf. (= Dendrobium densiflorum Lindl.).

Dendrobium Sw. sect. Densiflora Finet, Bull. Mus. Nat. Hist. (Paris) 9: 295-303 (1903).

Type species: Dendrobium densiflorum Lindl.

Dendrobium Sw. sect. Callista (Lour.) Schltr., Repert. Spec. Nov. Regni Veg., Beih. 1: 444-445 (1912).

Type species: Callista amabilis Lour. 
Epiphytic herbs. Roots thick, fleshy, white. Stems erect, fusiforme to clavate, often angular, pseudobulbous, comprising several to many internodes; Leaves one to five, coriaceous, terminal to subterminal, near sheathless. Inflorescence pendant, multi-flowered, arising from near terminal nodes, development as though being extruded like paste from the stem buds. Flowers yellow, white or pink, with or without contrasting orange or yellow labellum. Lateral sepals similar and thin textured, spreading. Petals broader and often with serrate erose margins. Labellum broadly orbicular with constricted base, lacking side lobes, the base continuous with column-foot, flexible but non-articulate; the upper surface papillose-pubescent, basal transverse callus, and concave base. Column short with prominent sunken stigma. Column-foot relatively short, with prominent shortly falcate staminodia and with distal, glabrous, shiny, basal nectiferous cavity. Anther cap elongate, glabrous. Pollinia four in two groups of two, obovateelongate, thin, glabrous, light yellow.

Distribution: South-East Asia.

Notes: The following species were recognized as belonging to this genus following detailed research of types and the literature.

Callista amabilis Lour., Fl. Cochinch. 2: 519 (1790).

Callista densiflora (Lindl.) Kuntze, Rev. Gen. PI. 2: 654 (1891).

Callista farmeri (Paxt.) Kuntze, Rev. Gen. PI. 2: 654 (1891).

Callista griffithiana (Lindl.) Kuntze, Rev. Gen. Pl. 2: 654 (1891).

Callista guibertii (Carriere) M.A.Clem., comb. nov.

Basionym: Dendrobium guibertii Carriere, Rev. Hortic. 48: 430 (1876).

Callista palpebrae (Lindl.) Kuntze, Rev. Gen. PI. 2: 655 (1891).

Callista thyrsiflora (Rchb.f.) M.A.Clem., comb. nov.

Basionym: Dendrobium thyrsiflorum Rchb.f. in Andre, Illustr. Hortic. 22: 88, t. 207 (1875).

\section{Fifth major group}

Ceraia Lour., Fl. Cochinch. 2: 518 (1790) (as 'Ceraja').

Type species: Ceraia simplicissima Lour.

Dendrobium Sw. sect. Crumenata Pfitz. in Engl. et Prantl, Pflanzenr. II (6): 174 (1889).

Type species: Dendrobium crumenatum Sw.

Dendrobium Sw. subgen. Crumenata Kraenzl. in Engl., Pflanzenr. Orch.-Mon.-Dend. 1: 224 (1910).

Aporum Blume sect. Crumenata (Pfitz.) Brieger, Schltr., Die Orchideen 1(11-12): 671 (1981).

Dendrobium Sw. sect. Ampullaria Pfitz. in Engl. et Prantl, Pflanzenr. II (6): 174 (1889).

Type species: Dendrobium planibulbe Lindl.

Dendrobium Sw. subgen. Rhopalobium Schltr. sect. Ceraia Schltr., Repert. Spec. Nova. Regni Veg., Beih. 1: 442, 449 (1914).

Type species: Dendrobium crumenatum Sw.

Aporum Blume sect. Linearifolia Brieger in Schltr., Die. Die Orchideen 674 (1981).

Type species: Onychium gracile Blume (= Dendrobium linearifolium Teijsm. et Binn.).

Dendrobium Sw. sect. Rhopolanthe Schltr. subsect. Aporopsis Schltr., Repert Spec. Nov. Regni Veg., Beih. 1: 565 (1912), nom. nud.

Aporum Blume sect. Aporopsis (Schltr.) Brieger, Schltr., Die Orchideen 674 (1981), nom. inval. Type species: Onychium tetraedre Blume

Aporopsis (Schltr.) M.A.Clem. et D.L. Jones, Orchadian 13(11): 485 (2002), nom. inval. Type species: Dendrobium macfarlanei F.Muell.

Dendrobium Sw. sect. Virgatae Hook.f., Fl. Brit. Ind. 5: 711, 726 (1890), pro parte min. 
Epiphytic or lithophytic herb; pseudobulbous stems to c. $1 \mathrm{~m}$ long, the swollen part comprising three or four nodes and internodes at least four nodes from the base of a shoot; aerial growths arising above the swollen pseudobulb, capable of forming a swollen pseudobulb; roots arising from the nodes at the base of each shoot; sheaths overlapping; inflorescence enclosed in a covering sheath, a highly reduced indeterminate, raceme; flowers one to three per inflorescence, spontaneous at any time following a drop in air temperature, and synchronous for all plants in the same area; flowers lasting only a few hours in a single day, of superficial substance; very fragrant perfume; labellum non-articulate, attached directly to base of column-foot where it forms a short spur containing nectar; column-foot longer than column. Stelidia reduced not divided. Pollinia four, obliquely elliptical, loosely held together in two groups of two. Capsule fusiforme. Protocorm-seedling type, narrowly isobilateral.

Distribution: Frequent throughout South-East Asia, and the Malay archipelago including Christmas Island which is an Australian Territory, and as far east as Papua New Guinea.

Notes: The following species are transferred or recognised as belonging to this genus following detailed research of Types and the literature.

Ceraia acaciifolia (J.J.Sm.) M.A.Clem., comb. nov.

Basionym: Dendrobium acaciifolium J.J.Sm., Bull. Jard. Bot. Buitenzorg (ser. 2), 25: 34-36 (1917).

Ceraia acicularis (Lindl.) M.A.Clem. comb. nov.

Basionym: Dendrobium aciculare Lindl., Edwards' Bot. Reg. 26: 81, misc. 188 (1840).

Ceraia alabensis (J.J.Wood) M.A.Clem. comb. nov.

Basionym: Dendrobium alabense J.J.Wood, Lindleyana, 5(2): 90 (1990).

Ceraia aurantiflammea (J.J.Wood) M.A.Clem. comb. nov.

Basionym: Dendrobium aurantiflammeum J.J.Wood, Orchid Rev. 106: 337-342, f. (1998).

Ceraia batanensis (Ames et Quisumb.) M.A.Clem., comb. nov.

Basionym: Dendrobium batanense Ames et Quisumb., Philipp. J. Sc. 47: 200, f. (1932).

Ceraia boothii (Teijsm. et Binn.) M.A.Clem. comb. nov.

Basionym: Dendrobium boothii Teijsm. et Binn., Natuurk. Tijdschr. Ned.-Indie 24: 318 (1862).

Ceraia bukidnonensis (Ames et Quisumb.) M.A.Clem., comb. nov.

Basionym: Dendrobium bukidnonense Ames et Quisumb., Philipp. J. Sc. 59: 5 (1936).

Ceraia calceola (Roxb.) M.A.Clem., comb. nov.

Basionym: Dendrobium calceolum Roxb., Hort. Beng. 63 (1814), nom. nud.; Fl. Ind. 3: 488 (1832).

Ceraia carinata (L.) M.A.Clem., comb. nov.

Basionym: Epidendrum carinatum L., Sp. Pl. 1350 (1753); Dendrobium carinatum (L.) Willd., Sp. PI. 4: 133-134 (1805).

Ceraia chrysotainia (Schltr.) M.A.Clem., comb. nov.

Basionym: Dendrobium chrysotainium Schltr., Repert. Spec. Nov. Regni Veg. 8: 508 (1910).

Ceraia cinnabarina (Rchb.f.) M.A.Clem. comb. nov.

Basionym: Dendrobium cinnabarinum Rchb.f., Gard. Chron. 14: 166 (1880).

Ceraia clavator (Ridl.) M.A.Clem. comb. nov.

Basionym: Dendrobium clavator Ridl., J. Linn. Soc. 32: 255 (1896).

Ceraia compressicaulis (J.J.Sm.) M.A.Clem. comb. nov.

Basionym: Dendrobium compressicaule J.J.Sm., Bull. Jard. Bot. Buitenzorg (ser. 3), 10: 57-58 (1928).

Ceraia confunda (Kraenzl.) M.A.Clem., comb. nov.

Basionym: Dendrobium confundens Kraenzl. in Engl., Pflanzenr. Orch.-Mon.-Dendr. 1: 205 (1910).

Ceraia cultrifolia (Schltr.) M.A.Clem., comb. nov.

Basionym: Dendrobium cultrifolium Schltr., Repert. Spec. Nov. Regni Veg. 16: 111 (1919).

Ceraia cuneata (Schltr.) M.A.Clem., comb. nov.

Basionym: Dendrobium cuneatum Schltr., Bull. Herb. Boiss. (ser. 2) 6: 454-455 (1906).

Ceraia cuneilabra (J.J.Sm.) M.A.Clem. comb. nov.

Basionym: Dendrobium cuneilabrum J.J.Sm., Icon. Bogor. 3: 11-12, t. 205 (1906). 
Ceraia cymbulipes (J.J.Sm.) M.A.Clem. comb. nov.

Basionym: Dendrobium cymbulipes J.J.Sm., Mitt. Inst. Bot. Hamburg 7: 51, t. 8, f. 41 (1927).

Ceraia dentata (Seidenf.) M.A.Clem. comb. nov.

Basionym: Dendrobium dentatum Seidenf., Nordic J. Bot., 1(2): 206 (1981).

Ceraia eboracensis (Kraenzl.) M.A.Clem., comb. nov.

Basionym: Dendrobium eboracense Kraenzl., Oest. Bot. Zeitschr. 44: 419 (1894).

Ceraia ephemera (J.J.Sm.) M.A.Clem. comb. nov.

Basionym: Dendrobium ephemerum J.J.Sm. in Merrill, Interpr. Rumph. Herb. Amboin. 174 (1917)

Ceraia equitans (Kraenzl.) M.A.Clem., comb. nov.

Basionym: Dendrobium equitans Kraenzl. in Engl., Pflanzenr. Orch.-Mon.-Dendr. 1: 228 (1910).

Ceraia exilis (Schltr.) M.A.Clem., comb. nov.

Basionym: Dendrobium exile Schltr., Repert. Spec. Nov. Regni Veg. 2: 85 (1906).

Ceraia facifera (J.J.Sm.) M.A.Clem. comb. nov.

Basionym: Dendrobium faciferum J.J.Sm., Bull. Dép. Agric. Indes Néerl. 15: 10 (1908).

Ceraia fimbriata (Blume) M.A.Clem. comb. nov

Basionym: Onychium fimbriatum Blume, Bijdr. 325 (1825); Dendrobium blumei Lindl., Gen. Sp. Orch. Pl. 88 (1830), nom

Ceraia fugax M.A.Clem., nom. nov.

Basionym: Dendrobium fugax Schltr., Bull. Herb. Boiss. (ser. 2), 6: 455 (1906), nom. illeg., non Rchb.f. (1871).

Ceraia gedeana (J.J.Sm.) M.A.Clem., comb. nov.

Basionym: Dendrobium gedeanum J.J.Sm., Bull. Dép. Agric. Indes Néerl. 8: 29 (1907).

Ceraia gerlandiana (Kraenzl.) M.A.Clem., comb. nov.

Basionym: Dendrobium gerlandianum Kraenzl., Repert. Spec. Nov. Regni Veg. 6: 317 (1909).

Ceraia goldfinchii (F.Muell.) M.A.Clem., comb. nov.

Basionym: Dendrobium goldfinchii F.Muell., Wings South Sc. Record 3: 4 (Jan. 1883).

Ceraia gracilis (Blume) M.A.Clem. comb. nov.

Basionym: Onychium gracile Blume, Bijdr. 327 (1825).

Ceraia grootingsii (J.J.Sm.) M.A.Clem. comb. nov.

Basionym: Dendrobium grootingsii J.J.Sm., Bull. Jard. Bot. Buitenzorg (ser. 2), 25: 33-34 (1917).

Ceraia gynoglottis (Carr) M.A.Clem. comb. nov.

Basionym: Dendrobium gynoglottis Carr, Gard. Bull. Straits Settlements 8: 105 (1935).

Ceraia humboldtensis (J.J.Sm.) M.A.Clem., comb. nov.

Basionym: Dendrobium humboldtense J.J.Sm., Repert. Spec. Nov. Regni Veg. 11: 131 (1912).

Ceraia hymenocentra (Schltr.) M.A.Clem., comb. nov.

Basionym: Dendrobium hymenocentrum Schltr., Repert. Spec. Nov. Regni Veg., Beih. 1: 567 (1912).

Ceraia hymenopetala (Schltr.) M.A.Clem., comb. nov.

Basionym: Dendrobium hymenopetalum Schltr., Bot. Jahrb. Syst. 45, Beibl. 104: 33 (1911).

Ceraia hypopoga (Kraenzl.) M.A.Clem. comb. nov.

Basionym: Dendrobium hypopogon Kraenzl. in Engl., Pflanzenr. Orch.-Mon.-Dendr. 1: 232-234 (1910).

Ceraia inconcinna (Ridl.) M.A.Clem. comb. nov.

Basionym: Dendrobium inconcinnum Ridl., J. Linn. Soc. 32: 255 (1896).

Ceraia inconspicua (J.J.Sm.) M.A.Clem., comb. nov.

Basionym: Dendrobium inconspicuum J.J.Sm. in L. S. Gibbs, Phytogeogr. \& Fl. Arfak Mts. 205 (1917).

Ceraia incurvociliata (J.J.Sm.) M.A.Clem. comb. nov.

Basionym: Dendrobium incurvociliatum J.J.Sm., Bull. Jard. Bot. Buitenzorg (ser. 3), 11: 137-138 (1931).

Ceraia juncea (Lindl.) M.A.Clem., comb. nov.

Basionym: Dendrobium junceum Lindl., Edwards' Bot. Reg. 28, Misc. 11 (1842). 
Ceraia juncifolia (Schltr.) M.A.Clem., comb. nov.

Basionym: Dendrobium juncifolium Schltr., Repert. Spec. Nov. Regni Veg. 10: 76 (1911).

Ceraia koeteiana (Schltr.) M.A.Clem. comb. nov.

Basionym: Dendrobium koeteianum Schltr., Bull. Herb. Boissier (ser. 2), 6: 456 (1906).

Ceraia kohlmeyeriana (Teijsm. et Binn. ex Miq.) M.A.Clem. comb. nov.

Basionym: Dendrobium kohlmeyerianum Teijsm. et Binn. ex Miq., Choix, Pl. Jard. Buitenzorg t. 24. f.1 (1867).

Ceraia kurashigei (T.Yakawa) M.A.Clem., comb. nov.

Basionym: Dendrobium kurashigei T.Yakawa, Lindleyana 13(1): 28-30, f.2 (1998).

Ceraia lagara (Schltr.) M.A.Clem., comb. nov.

Basionym: Dendrobium lagarum Seidenf., Opera Bot. 83: 187 (1985).

Ceraia lamatochila (Seidenf.) M.A.Clem. comb. nov.

Basionym: Dendrobium lamatochilum Seidenf., Nordic J. Bot. 1(2):206 (1981).

Ceraia lamellifera (Carr) M.A.Clem. comb. et stat. nov.

Basionym: Dendrobium cinnabarinum Rchb.f. var. lamelliferum Carr, Gard. Bull. Straits Settlem. 8: 103 (1935).

Ceraia lamellulifera (J.J.Sm.) M.A.Clem. comb. nov.

Basionym: Dendrobium lamelluliferum J.J.Sm., Mitt. Inst. Bat. Hamburg 7: 52, t. 8, f. 42 (1927).

Ceraia lanciloba (J.J.Wood) M.A.Clem. comb. nov.

Basionym: Dendrobium lancilobum J.J.Wood, Lindleyana 5(2): 90 (1990).

Ceraia lawiensis (J.J.Sm.) M.A.Clem. comb. nov.

Basionym: Dendrobium lawiense J.J.Sm., Bull. Jard. Bot. Buitenzorg (ser. 2), 3: 60 (1912).

Ceraia limii (J.J. Wood) M.A.Clem. comb. nov.

Basionym: Dendrobium limii J.J. Wood in J.J.Wood et P.J.Cribb, Checklist Orch. Borneo 254-255, f. 31 (1994).

Ceraia linearifolia (Teijsm. et Binn.) M.A.Clem. comb. nov.

Basionym: Dendrobium linearifolium Teijsm. et Binn., Tijdschr. Nederl. Ind. 24: 318 (1862).

Ceraia litoralis (Schltr.) M.A.Clem., comb. nov.

Basionym: Dendrobium litorale Schltr., Repert. Spec. Nov. Regni Veg., Beih. 1: 567 (1912).

Ceraia macfarlanei (F.Muell.) M.A.Clem., comb. nov.

Basionym: Dendrobium macfarlanei F.Muell., Papuan Pl. 1: 29 (1875).

Ceraia macrapora (J.J.Sm.) M.A.Clem., comb. nov.

Basionym: Dendrobium macraporum J.J.Sm., Bull. Jard. Bot. Buitenzorg (ser. 2), 8: 38 (1912).

Ceraia maleolens (Kraenzl.) M.A.Clem. comb. nov.

Basionym: Dendrobium maleolens Kraenzl. in Engl., Pflanzenr. Orch.-Mon.-Dendr. 1: 54 (1910).

Ceraia minima (Ames et C.Schweinf.) M.A.Clem. comb. nov.

Basionym: Dendrobium minimum Ames et C.Schweinf., Orchidaceae 6: 107, t. 91 (1920).

Ceraia modesta (Rchb.f.) M.A.Clem., comb. nov.

Basionym: Dendrobium modestum Rchb.f., Bonplandia 3: 222 (1855).

Ceraia multiramosa (Ames) M.A.Clem., comb. nov.

Basionym: Dendrobium multiramosum Ames, Orchidaceae 5: 129 (1915).

Ceraia odorata (Schltr.) M.A.Clem. comb. nov.

Basionym: Dendrobium odoratum Schltr., Repert. Spec. Nov. Regni Veg. 8: 503-504 (1910).

Ceraia ovatipetala (J.J.Sm.) M.A.Clem. comb. nov.

Basionym: Dendrobium ovatipetalum J.J.Sm., Bull. Jard. Bot. Buitenzorg (ser. 3), 12: 134-135 (1932).

Ceraia papilionifera (J.J.Sm.) M.A.Clem. comb. nov.

Basionym: Dendrobium papilioniferum J.J.Sm., Orch. Ambon 49 (1905).

Ceraia parviflora (Ames et C.Schweinf.) M.A.Clem. comb. nov.

Basionym: Dendrobium crumenatum Sw. var. parviflorum Ames et C.Schweinf., Orchidaceae 6: 100-101 (1920). 
Ceraia patentiloba (Ames et C.Schweinf.) M.A.Clem., comb. nov.

Basionym: Dendrobium patentilobum Ames et C.Schweinf., Orchidaceae 6: 110-112 (1920).

Ceraia peculiaris (J.J.Sm.) M.A.Clem. comb. nov.

Basionym: Dendrobium peculiare J.J.Sm., Bull. Jard. Bot. Buitenzorg (ser. 3), 10: 58-59 (1928).

Ceraia philippinensis (Ames) M.A.Clem., comb. nov.

Basionym: Dendrobium philippinense Ames, Philipp. J. Sc. Bot. 8: 424 (1914).

Ceraia planibulbis (Lindl.) M.A.Clem., comb. nov.

Basionym: Dendrobium planibulbe Lindl., Edwards'Bot. Reg. 29: 70, misc. 54. (1843).

Ceraia platybasis (Ridl.) M.A.Clem. comb. nov.

Basionym: Dendrobium platybasis Ridl., Trans. Linn. Soc., Bot. 9: 165 (1916).

Ceraia plebeja (J.J.Sm.) M.A.Clem. comb. nov.

Basionym: Dendrobium plebejum J.J.Sm., Bull. Dép. Agric. Indes Néerl. 5: 6-7 (1907).

Ceraia polytricha (Ames) M.A.Clem., comb. nov.

Basionym: Dendrobium polytrichum Ames, Orchidaceae 2: 183-184 (1908).

Ceraia pseudocalceola (J.J.Sm.) M.A.Clem., comb. nov.

Basionym: Dendrobium pseudocalceolum J.J.Sm., Bull. Dép. Agric. Indes Néerl. 5: 34 (1907).

Ceraia pseudoequitans (H.Fessel et E.Luckel) M.A.Clem., comb. nov.

Basionym: Dendrobium pseudoequitans H.Fessel et E.Luckel, Die Orchidee 51(1): 83-85, t. (2000).

Ceraia pseudotenella (Guillaumin) M.A.Clem., comb. nov.

Basionym: Dendrobium pseudotenellum Guillaumin, Bull. Mus. Hist. Nat. Paris (ser. 2), 36: 697 (1965).

Ceraia puberilinguis (J.J.Sm.) M.A.Clem., comb. nov.

Basionym: Dendrobium puberilingue J.J.Sm., Mitt. Inst. Allg. Bot. Hamburg 7: 53, t. 8., f. 43 (1927).

Ceraia ridleyana M.A.Clem., nom. nov.

Basionym: Dendrobium ridleyanum Kerr, Kew Bull. 218 (1927) nom. illeg, non Schltr. (1905).

Ceraia robinsonii (Ames) M.A.Clem., comb. nov.

Basionym: Dendrobium robinsonii Ames, Philipp. J. Sc., Bot. 8: 425 (1914).

Ceraia saaronica (J.König) M.A.Clem. et D.L.Jones, Orchadian 13(11): 486 (2002).

Basionym: Epidendrum saaronicum J.König, Retz. Obs. 6: 58 (1791). Angraecum crumenatum Rumph.

Herb. Amb. 6: t. 472 (1750), nom. illeg. (pre 1753). Dendrobium crumenatum Sw., Schrad. J. Bot. 2: 237 (1799).

Ceraia sanguinea M.A.Clem. nom. nov.

Basionym: Dendrobium sanguineum Rolfe, Gard. Chron. (ser. 3) 18: 292 (1895), non Sw. (1799).

Ceraia scirpoides (Schltr.) M.A.Clem., comb. nov.

Basionym: Dendrobium scirpoides Schltr., Repert. Spec. Nov. Regni Veg. 9: 103 (1911).

Ceraia setifera M.A.Clem., nom. nov.

Basionym: Dendrobium tenellum (Blume) Lindl. var. setifolium Guillaumin, Bull. Mus. Paris (ser. 2), 28: 484 (1956).

Ceraia setifolia (Ridl.) M.A.Clem., comb. nov.

Basionym: Dendrobium setifolium Ridl., J. Linn. Soc. 31: 270 (1896).

Ceraia simplicissima Lour., FI. Indoch. 578 (1790). Dendrobium podagraria Hook.f., Fl. Brit. Ind. 5: 728 (1890); Icon. Pl. t. 2026 (1890)

Ceraia stelidiifera (J.J.Sm.) M.A.Clem., comb. nov.

Basionym: Dendrobium stelidiiferum J.J.Sm., Bull. Jard. Bot. Buitenzorg (ser. 3), 2: 66-67 (1920).

Ceraia strigosa (Schltr.) M.A.Clem., comb. nov.

Basionym: Dendrobium strigosum Schltr., Bot. Jahrb. Syst. 45, Beibl. 104, 34 (1911)

Ceraia tenella (Blume) M.A.Clem., comb. nov.

Basionym: Onychium tenellum Blume, Bijdr. 327 (1825).

Ceraia tenuis (J.J.Sm.) M.A.Clem., comb. nov.

Basionym: Dendrobium tenue J.J.Sm., Bull. Jard. Bot. Buitenzorg (ser. 2), 25: 31-33 (1917). 
Ceraia tenuicaulis (Hook.f.) M.A.Clem., comb. nov.

Basionym: Dendrobium tenuicaule Hook.f., Fl. Brit. Ind. 6: 184 (1890).

Ceraia tetraedris (Blume) M.A.Clem., comb. nov. Basionym: Onychium tetraedre Blume, Bijdr. 327 (1825).

Ceraia torajaensis (O’Byrne) M.A.Clem., comb. nov. Basionym: Dendrobium torajaense O'Byrne, Malayan Orchid Rev. 33: 45-46, 95, f., t. (1999).

Ceraia tricuspis (Blume) M.A.Clem., comb. nov.

Basionym: Onychium tricuspe Blume, Bijdr. 326 (1825).

Ceraia tridentata (Ames et C.Schweinf.) M.A.Clem., comb. nov.

Basionym: Dendrobium tridentatum Ames et C.Schweinf., Orchidaceae 6: 115-117 (1920).

Ceraia truncata (Lindl.) M.A.Clem. comb. nov.

Basionym: Dendrobium truncatum Lindl., J. Linn. Soc. 3: 15 (1859).

Ceraia usterii (Schltr.) M.A.Clem., comb. nov.

Basionym: Dendrobium usterii Schltr., Bull. Herb. Boiss. (ser. 2), 6: 458-459 (1906)

Ceraia usterioides (Ames) M.A.Clem., comb. nov.

Basionym: Dendrobium usterioides Ames, Orchidaceae 5: 142 (1915).

Ceraia ventricosa (Kraenzl.) M.A.Clem., comb. nov.

Basionym: Dendrobium ventricosum Kraenzl. in Engl., Pflanzenr. Orch.-Mon.-Dendr. 1: 209 (1910).

Ceraia ventripes (Carr) M.A.Clem., comb. nov.

Basionym: Dendrobium ventripes Carr, Gard. Bull. Straits Settlem. 8: 103 (1935).

Aporum Blume, Bijdr. 6: f. 39; 7: 334 (1825).

Type species: Aporum lobatum Blume (vide Brieger 1981), non Aporum indivisum Blume (vide Seidenfaden 1985)

Macrostomium Blume, Bijdr. 335 (1825); Aporum Blume sect. Macrostomium (Blume) Bieger, Schltr., Die Orchideen 3 (ed. 1): 676 (1981).

Type species: Macrostomium aloifolium Blume

Schismoceras Presl, Rel. Haenk. 1: 96-97, t. 13, f. 2a-e (1827).

Type species: Schismoceras disticha Presl.

Ditulima Rafin., Fl. Tellur. 4: 41 (1836)[1838].

Type species: Ditulima anceps Raf. (= Dendrobium anceps Sw.)

Dendrobium Sw. sect. Aporum (Blume) Lindl. in Paxt., Fl. Gard. 1: 134 (1851).

Aporum Blume sect. Aporum Brieger, Schltr., Die Orchideen, 3 Aufl. 1: 677 (1981).

Erect, porrect or pendulous, small to large, epiphytic or lithophytic, herbs. Roots thin wiry, divided. Stems thin, wiry, covered with lead sheaths for most of their length but exposed in most species towards the apex, often branching. Leaves equitant, hard, fleshy, broadest near the basal half of each stem, then tapering towards the apex, with a distinct abscission layer, apices acute, persistent for several years, those nearest the apex becoming increasingly smaller and bract like. Inflorescence lateral on exposed apical part of stem, the bract from successive flowering forming a tuft at each node, comprising one or a few flowers. Flowers solitary arising from a lateral meristematic persistent inflorescence, lasting only a few days, synchronous with other plants of the same species in the immediate vicinity; fleshy. Lateral sepals connate at base and spreading towards the apices, together with the labellum and column-foot forming a small spur or saccate base. Dorsal sepal free often much smaller than the lateral sepals. Petals free and often smaller than the dorsal sepal. Labellum fleshy, sessile, rigid with distinct thickened callus of small glands on the laminar surface. Column short with truncate apex, and prominent staminodes. Pollinia small, hard waxy, yellow in two globose hemipollinia. Protocorm-seedling type narrowly isobilateral.

Distribution: throughout South-East Asia and Malesia.

Aporum acinaciforme (Roxb.) Griff., Cal. J. Nat. Hist. 5: 370 (1845).

Aporum albayense (Ames) M.A.Clem., comb. nov.

Basionym: Dendrobium albayense Ames, Philipp. J. Sc., Bot. 7: 14 (1912). 
Aporum aloifolium (Blume) Brieger, Schltr., Die Orchideen, 3 Aufl. 1: 676 (1981).

Aporum anceps (Sw.) Lindl., Gen. Sp. Orch. Pl. 71 (1830).

Aporum auyongii (T.Yukawa) M.A.Clem. comb. nov. Basionym: Dendrobium auyongii T.Yukawa, Lindleyana 13(1): 28, f.1 (1998).

Aporum babiense (J.J.Sm.) Rauschert, Feddes Repert. 94(7-8): 438 (1983).

Aporum banaense (Gagnep.) Rauschert, Feddes Repert. 94(7-8): 438 (1983).

Aporum basilanense (Ames) M.A.Clem. comb. nov.

Basionym: Dendrobium basilanense Ames, Philipp. J. Sc., Bot. 7: 14-15 (1912).

Aporum bicornutum (Schltr.) Rauschert, Feddes Repert. 94(7-8): 438 (1983).

Aporum bilobulatum (Seidenf.) M.A.Clem. comb. nov.

Basionym: Dendrobium bilobulatum Seidenf., Opera Bot. 83: 218, f. 147 (1985).

Aporum brevimentum (Seidenf.) M.A.Clem. comb. nov.

Basionym: Dendrobium brevimentum Seidenf., Opera Bot. 83: 225-226, f. 154 (1985).

Aporum calceolariae (J.König) M.A.Clem., comb. nov.

Basionym: Epidendrum calceolariae J.König, Retz. Obs. 6: 45 (1791). Dendrobium acerosum Lindl., Edwards' Bot. Reg. 30: misc. 86 (1841).

Aporum capitellatoides (J.J.Sm.) Rauschert, Feddes Repert. 94(7-8): 438 (1983).

Aporum capitellatum (J.J.Sm.) Rauschert, Feddes Repert. 94(7-8): 438 (1983).

Aporum cochinchinense (Ridl.) Rauschert, Feddes Repert. 94(7-8): 438 (1983).

Aporum compressistylum (J.J.Sm.) Rauschert, Feddes Repert. 94(7-8): 438 (1983).

Aporum concavum (J.J.Sm.) Rauschert, Feddes Repert. 94(7-8): 438 (1983).

Aporum confusum (Schltr.) M.A.Clem., comb. nov.

Basionym: Dendrobium confusum Schltr., Repert. Spec. Nov. Regni Veg. 10: 72 (1911).

Aporum crucilabre (J.J.Sm.) Rauschert, Feddes Repert. 94(7-8): 438 (1983).

Aporum curviflorum (Rolfe) M.A.Clem., comb. nov.

Basionym: Dendrobium curviflorum Rolfe, Kew Bull. 281(1805).

Aporum dalatense (Gagnep.) Rauschert, Feddes Repert. 94(7-8): 439 (1983).

Aporum diaphanum (Schltr.) Rauschert, Feddes Repert. 94(7-8): 439 (1983).

Aporum distichum (Presl.) Rauschert, Feddes Repert. 94(7-8): 438 (1983).

Aporum escritorii (Ames) M.A.Clem., comb. nov.

Basionym: Dendrobium escritorii Ames, Orchidaceae 5: 123 (1915).

Aporum ferdinandi (Kraenzl.) M.A.Clem., comb. nov.

Basionym: Dendrobium ferdinandi Kraenzl. in Engl., Pflanzenr. Orch.-Mon.-Dendr. 1: 209 (1910).

Aporum flexile (Ridl.) Rauschert, Feddes Repert. 94(7-8): 439 (1983).

Aporum fuscum (O'Byrne) M.A.Clem., comb. et stat. nov.

Basionym: Dendrobium indivisum (Blume) Miq. var. fuscum O'Byrne, Malayan Orch. Rev. 31: 21-22, 77, t. f. (1997).

Aporum grande (Hook.f.) Rauschert, Feddes Repert. 94(7-8): 439 (1983).

Aporum indivisum Blume, Bijdr. 6: 334. t. 39 (1825).

Aporum jenkinsii Griff., Calc. J. Nat. Hist. 5: 367, t. 25 ( 1854). Dendrobium parciflroum Rchb.f. ex Lindl., J.Linn. Soc. 3: 4 (1859).

Aporum jennae (O’Byrne) M.A.Clem., comb. nov.

Basionym: Dendrobium jennae O'Byrne, Malayan Orch. Rev. 30: 24 (1996).

Aporum keithii (Ridl.) M.A.Clem., comb. nov.

Basionym: Dendrobium keithii Ridl., J. Linn. Soc. 32: 247-248 (1896). 
Aporum kentrophyllum (Hook.f.) Brieger, Schltr., Die Orchideen 3 (ed. 1): 676 (1981).

Aporum kiauense (Ames et C.Schweinf.) M.A.Clem., comb. nov.

Basionym: Dendrobium kiauense Ames et C.Schweinf., Orchidaceae 6: 103-105 (1920).

Aporum kjellbergii (J.J.Sm.) Rauschert, Feddes Repert. 94(7-8): 440 (1983).

Aporum korthalsii (J.J.Sm.) Rauschert, Feddes Repert. 94(7-8): 440 (1983).

Aporum kuyperi (J.J.Sm.) Rauschert, Feddes Repert. 94(7-8): 440 (1983).

Aporum leonis Lindl. in Edwards', Bot. Reg. 26: misc. 59-60 (1840).

Aporum litoreum (F.M.Bailey) M.A.Clem., comb. nov.

Basionym: Dendrobium litoreum F.M.Bailey, Queensl. Agric. J. 16: 411 (1906).

Aporum lobatum Blume, Bijdr. 6: 334 (1825).

Aporum lobbii M.A.Clem., nom. nov.

Basionym: Dendrobium lobbii Lindl., J. Linn. Soc. 3: 3 (1859), non Teijsm. et Binn. (1853).

Aporum Iobulatum (Rolfe ex J.J.Sm.) Brieger, Schltr., Die Orchideen 3 Aufl. 1: 677 (1981).

Aporum lunatum (Lindl.) M.A.Clem., comb. nov.

Basionym: Dendrobium lunatum Lindl., J. Linn. Soc. 3: 4 (1859).

Aporum macgregorii M.A.Clem., nom. nov.

Basionym: Dendrobium macgregorii Ames, Philipp. J. Sc., Bot. 7: 17-18 (1912), non F.Muell. et Kraenzl. (1894); Dendrobium quisumbingii A.D.Hawkes et A.H.Heller, Lloydia 20: 123 (1957), nom.

Aporum mannii (Ridl.) Rauschert, Feddes Repert. 94(7-8): 440 (1983).

Aporum marivelense (Ames) Rauschert, Feddes Repert. 94(7-8): 440 (1983).

Aporum merrillii (Ames) M.A.Clem., comb. nov.

Basionym: Dendrobium merrillii Ames, Orchidaceae 2: 181-182, f. (1908).

Aporum mindanaense (Ames) M.A.Clem., comb. nov.

Basionym: Dendrobium mindanaense Ames, Philipp. J. Sc., Bot. 8: 423 (1914).

Aporum mirandum (Schltr.) Rauschert, Feddes Repert. 94(7-8): 440 (1983).

Aporum modestissimum (Kraenzl.) M.A.Clem., comb. nov.

Basionym: Dendrobium modestissimum Kraenzl. in Engl., Pflanzenr. Orch.-Mon.-Dendr. 1: 206-207 (1910).

Aporum nathanielis (Rchb.f.) M.A.Clem., comb. nov.

Basionym: Dendrobium nathanielis Rchb.f. in Schill., Cat. Orch. (ed. 3). 26 (1857).

Aporum nycteridoglossum (Rchb.f.) Rauschert, Feddes Repert. 94(7-8): 441 (1983).

Aporum pendulicaule (Hayata) Rauschert, Feddes Repert. 94(7-8): 441 (1983).

Aporum porphyrophyllum (Guillaumin) M.A.Clem., comb. nov.

Basionym: Dendrobium porphyrophyllum Guillaumin, Bull. Mus. Hist. Nat. Paris (ser. 2), $27: 395$ (1955).

Aporum prostratum (Ridl.) Rauschert, Feddes Repert. 94(7-8): 441 (1983).

Aporum pseudoaloifolium (J.J.Wood) M.A.Clem., comb. nov.

Basionym: Dendrobium pseudoaloifolium J.J.Wood, Kew Bull., 39(1): 82-84, f. 7 (1984).

Aporum pseudoequitans (H.Fessel et E.Lückel) M.A.Clem., comb. nov.

Basionym: Dendrobium pseudoequitans H.Fessel et E.Lückel, Orchidee 51(1): 83 (2000).

Aporum quadrilobatum (Carr) Rauschert, Feddes Repert. 94(7-8): 441 (1983).

Aporum ramificans (J.J.Sm.) Rauschert, Feddes Repert. 94(7-8): 441 (1983).

Aporum reflexibarbatulum (J.J.Sm.) M.A.Clem., comb. nov.

Basionym: Dendrobium reflexibarbatulum J.J.Sm., Mitt. Inst. Bot. Hamburg 7: 54, t. 8., f. 44 (1927)

Aporum reflexitepalum (J.J.Sm.) Rauschert, Feddes Repert. 94(7-8): 441 (1983). 
Aporum rhodostele (Ridl.) Rauschert, Feddes Repert. 94(7-8): 441 (1983).

Aporum rhombopetalum (Kraenzl.) Rauschert, Feddes Repert. 94(7-8): 441 (1983).

Aporum rosellum (Ridl.) Rauschert, Feddes Repert. 94(7-8): 441 (1983).

Aporum roseonervatum (Schltr.) Rauschert, Feddes Repert. 94(7-8): 442 (1983).

Aporum roseostriatum (Ridl.) Rauschert, Feddes Repert. 94(7-8): 442 (1983).

Aporum sagittatum (J.J.Sm.) Rauschert, Feddes Repert. 94(7-8): 442 (1983).

Aporum salicornioides (Teijsm. et Binn.) Brieger in Schlechter Die Orchideen, 1(11-12): 676 (1981).

Aporum sambasanum (J.J.Sm.) M.A.Clem., comb. nov.

Basionym: Dendrobium sambasanum J.J.Sm., Bull. Dép. Agric. Indes Néerl. 22: 25 (1909).

Aporum shompenii (B.K.Sinha et P.S.N.Rao) M.A.Clem., comb. nov.

Basionym: Dendrobium shompenii B.K.Sinha et P.S.N.Rao, Nordic J. Bot., 18(1): 27-30, f. (1998).

Aporum sinuosum (Ames) M.A.Clem., comb. nov.

Basionym: Dendrobium sinuosum Ames, Orchidaceae 7: 96 (1922).

Aporum smithianum (Schltr.) Rauschert, Feddes Repert. 94(7-8): 442 (1983).

Aporum spatella (Rchb.f.) M.A.Clem., comb. nov.

Basionym: Dendrobium spatella Rchb.f., Hamb. Gartenz. 21: 298 (1865).

Aporum sphenochilum (F.Muell. et Kraenzl.) M.A.Clem., comb. nov.

Basionym: Dendrobium sphenochilum F.Muell. et Kraenzl., Oest. Bot. Zeitschr. 44(7): 254-255 (1894)

Aporum subpandifolium (J.J.Sm.) Rauschert, Feddes Repert. 94(7-8): 442 (1983).

Aporum subulatoides (Schltr.) Rauschert, Feddes Repert. 94(7-8): 442 (1983).

Aporum subulatum (Blume) Rauschert, Feddes Repert. 94(7-8): 442 (1983).

Aporum teloense (J.J.Sm.) Rauschert, Feddes Repert. 94(7-8): 442 (1983).

Aporum teres Rauschert, Feddes Repert. 94(7-8): 442 (1983).

Aporum terminale (Par. et Rchb.f.) M.A.Clem., comb. nov.

Basionym: Dendrobium terminale Par. et Rchb.f., Trans. Linn. Soc. 30: 149 (1874).

Aporum tetralobum (Schltr.) Rauschert, Feddes Repert. 94(7-8): 442 (1983).

Aporum thysanophorum (Schltr.) Rauschert, Feddes Repert. 94(7-8): 442 (1983).

Aporum uncatum (Lindl.) Brieger in Schltr., Die Orchideen 3 (ed. 1): 676 (1981).

Aporum vanhulstijnii (J.J.Sm.) Rauschert, Feddes Repert. 94(7-8): 443 (1983).

Aporum wenzelii (Ames) M.A.Clem., comb. nov.

Basionym: Dendrobium wenzelii Ames, Orchidaceae 5: 144 (1915).

Aporum xanthoacron (Schltr.) M.A.Clem., comb. nov.

Basionym: Dendrobium xanthoacron Schltr., Bull. Herb. Boiss. (ser. 2), 6: 459-460 (1906).

Aporum xiphophyllum (Schltr.) M.A.Clem., comb. nov.

Basionym: Dendrobium xiphophyllum Schltr., Repert. Spec. Nov. Regni Veg. 9: 291-292 (1911).

\section{Sixth major group}

Species in this clade are in need of much additional study. Present evidence suggests that the group as a whole could be treated as a single genus with a number of infrageneric taxa, the first available name being Coelandria. However, further study is required on the remaining species in this major group before a decision can be made on their phylogenetic relationships and status. In the interim, it is here proposed that only those species that clearly fall into a small group directly containing Coelandria smillieae, be transferred to that genus.

Coelandria Fitzg., Austral. Orch. 1(7): [t. 2] (1882).

Type species: Coelandria smillieae (F. Muell.) Fitzg. 
Erect, spreading to pendulous epiphytic, occasionally lithophytic herb. Stems robust, clustered, cylindric to cylindric-fusiform, not branching. Leaves membranous to leathery, seasonally deciduous, slightly recurved, linear-ovate to elliptic; sheaths slightly shorter to longer than internodes, papery, persistent. Inflorescences densely multi-flowered, bottle-brush like, lateral, usually on leafless stems; peduncle short, thick, cylindrical. Flowers, rigid, shiny, glabrous, white, pink, purple, orange, green, the labellum often contrasting in colour. Dorsal sepal small, ovate to obovate-oblong. Lateral sepals obliquely narrowly obovate to somewhat spatulate, fused at apex, truncate. Petals small, similar to dorsal sepal. Labellum cymbidiform, thick, fleshy, parallel to column-foot, embracing column, constricted nearest the base, fused to column-foot along basal margin, transverse callus. Column short, thick fleshy and very short stelidia, the stigma sunken, a prominent tooth-like, hard, rostellum, with large viscidia. Column-foot with central longitudinal groove, and nectary at base. Pollinia four, fused together, obovate, concave, light brown to blackish-blue, smooth waxy.

Distribution: Malesia and Australia.

Coelandria andreemillariae (T.M.Reeve) M.A.Clem., comb. nov.

Basionym: Dendrobium andreemillarae T.M.Reeve, Orchadian 7: 130, f. 1 (1982).

Coelandria chrysoglossa (Schltr.) M.A.Clem., comb. nov.

Basionym: Dendrobium chrysoglossum Schltr., Repert. Spec. Nov. Regni Veg., Beih. 1: 509-510 (1912).

Coelandria coccinea (Kraenzl.) M.A.Clem., comb. nov.

Basionym: Dendrobium coccineum Kraenzl. in Engl., Plfanz. Orch.-Mon.-Dendr. 1:129-130 (1910).

Coelandria concavissima (J.J.Sm.) M.A.Clem., comb. nov.

Basionym: Dendrobium concavissimum J. J. Sm., Bull. Jard. Bot. Buitenzorg (ser. 2) 2: 11 (1911).

Coelandria fornicata (Schltr.) M.A.Clem., comb. nov.

Basionym: Dendrobium fornicatum Schltr., Repert. Spec. Nov. Regni Veg., Beih. 1: 509 (1912).

Coelandria fracta (T.M.Reeve) M.A.Clem., comb. nov.

Basionym: Dendrobium fractum T. M. Reeve, Orchadian 7: 133-134, f. 3 (1982).

Coelandria glomerata (Rolfe) M.A.Clem., comb. nov.

Basionym: Dendrobium glomeratum Rolfe, Kew Bull. 1894: 155 (1894); Gard. Chron. 1: 653, f. 80 (1894).

Coelandria obtusa (Schltr.) M.A.Clem., comb. nov.

Basionym: Dendrobium obtusum Schltr. in K. Schum. et Lauterb., Nachtr. Fl. Schutzgeb. Südsee 177 (1905), non Rchb. f. (1861).

Coelandria smillieae (F. Muell.) Fitzg., Austral. Orch. 1(7): t. 2 (1882).

Basionym: Dendrobium smillieae F. Muell., Fragm. 6: 94 (1867); Callista smillieae (F. Muell.) Kuntze, Revis. Gen. Pl. 2: 655 (1891); Pedilonum smillieae (F. Muell.) Rauschert, Feddes Repert. 94: 464 (1983). 